\title{
KONTROL OPTIMUM \\ DAN METODE NUMERIKNYA \\ DALAM SCILAB
}

Effendi Syahril

Agah D. Garnadi 
Kontrol Optimum dan Metode Numeriknya dalam SCILAB

ISBN : 978-XXX-XXXX-XX-X

e-Book DOI : 10.31227/osf.io/kh4u2 


\section{Daftar Isi}

1 Pendahuluan $\quad 1$

1.1 Masalah Optimisasi Dinamis . . . . . . . . . . . . . . . . 1

1.2 State Sistem Dinamis . . . . . . . . . . . . . . . . . . 2

1.3 Peubah Kontrol . . . . . . . . . . . . . . . . . . . . . 3

1.4 Reachability, Controllability dan Observability . . . . . . . . . . . 4

1.5 Fungsional Objektif . . . . . . . . . . . . . . . . . . 4

1.6 Kalkulus Variasi dan Kontrol Optimum . . . . . . . . . . . . . . . . . 5

$\begin{array}{lll}2 & \text { Kalkulus Variasi } & 7\end{array}$

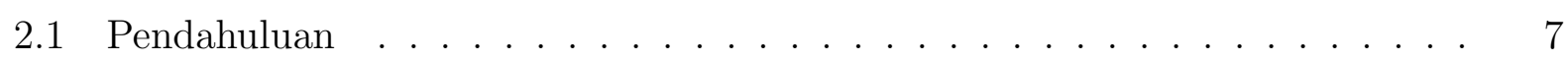

2.2 Fungsional Dan Variasi . . . . . . . . . . . . . . . . . 8

2.3 Syarat Perlu Untuk Optimum : Persamaan Euler . . . . . . . . . . . . . . . 9

2.4 Persamaan Euler Yang Lebih Umum . . . . . . . . . . . . . . . . . . . . 12

2.4.1 Kasus Peubah banyak . . . . . . . . . . . . . . . 12

2.4.2 Kasus Fungsi $f$ Memuat Turunan ke-n . . . . . . . . . . . . . . . 13

2.5 Kasus Khusus Persamaan Euler . . . . . . . . . . . . . . . . . . . . . . . 14

2.5.1 Fungsi $f$ Tidak Memuat $x \ldots \ldots$. . . . . . . . . . . . . . . . 14

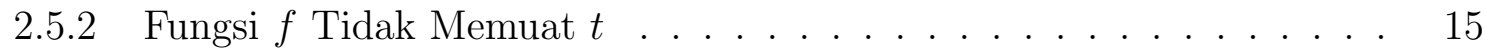


2.5.3 Fungsi $f$ Tidak Memuat $\dot{x} \ldots \ldots \ldots$. . . . . . . . . . 16

2.6 Masalah Variasi Dengan Kendala . . . . . . . . . . . . . . . . . 16

2.6.1 Kendala Titik Dan Kendala Persamaan Diferensial . . . . . . . . . . 17

2.6 .2 Kendala Isoperimetris . . . . . . . . . . . . . . . . . . . . . . . . 18

2.7 Syarat Batas Dalam Masalah Variasi . . . . . . . . . . . . . . . . . . . . 19

2.7.1 Dua Titik Ujung Tetap Dan Syarat Batas Natural . . . . . . . . . . . 19

2.7 .2 Titik Ujung Bebas . . . . . . . . . . . . . . . . . . . 21

2.8 Syarat Cukup / Sufficiency Conditions . . . . . . . . . . . . . . . 26

2.8.1 Variasi Fungsional . . . . . . . . . . . . . . . . 26

2.8.2 Syarat Legendre . . . . . . . . . . . . . . . . . . . . . 27

2.8.3 Syarat Jacobi . . . . . . . . . . . . . . . . . . . . . . . . . . . . . . 27

2.8.4 Syarat Weierstrass untuk Ekstremal Kuat . . . . . . . . . . . . . 27

2.8.5 Syarat Legendre-Clebsch . . . . . . . . . . . . . . . . . . 28

2.8.6 Syarat Cukup : Kasus khusus . . . . . . . . . . . . . . . . . . 28

3 Kontrol Optimum : Pendekatan Kalkulus Variasi 29

3.1 Formulasi Masalah Kontrol Optimum . . . . . . . . . . . . . . . . . . . . . . 29

3.2 Syarat Perlu : Prinsip Maksimum Pontryagin . . . . . . . . . . . . . . . 31

3.3 Syarat Transversalitas Atau Syarat Batas . . . . . . . . . . . . . . . . . . 37

3.3.1 Masalah Waktu Terminal T Tetap . . . . . . . . . . . . . . . . . . . 37

3.3.2 Masalah Waktu Terminal T Bebas . . . . . . . . . . . . . . . . . 38

3.4 Syarat Cukup Untuk Kontrol Optimum . . . . . . . . . . . . . . . . . . . . . 39

3.5 Current-Value Hamiltonian . . . . . . . . . . . . . . . . . . . . . . . . . 41

3.6 Beberapa contoh masalah nyata kontrol optimum . . . . . . . . . . . . . 43 
3.7 Peubah Kontrol Berbatas . . . . . . . . . . . . . . . . . . 46

3.7.1 Masalah Kontrol Optimum dengan Peubah Keadaan Berbatas . . . . 47

3.7.2 Masalah Kontrol Optimum dengan Kendala Persamaan . . . . . . . . 48

3.7.3 Masalah Kontrol Optimum dengan Peubah Kontrol Berbatas . . . . . 49

3.8 Kontrol Optimum Linier . . . . . . . . . . . . . . . . . . . . . 50

3.9 Soal-soal Latihan . . . . . . . . . . . . . . . . . . . . . 54

3.9.1 Soal-soal Kalkulus Variasi . . . . . . . . . . . . . . . 54

3.9.2 Soal-Soal Kontrol Optimum . . . . . . . . . . . . . . 57

4 Penyelesaian Masalah Kontrol Optimum Sebagai Masalah Syarat Batas Persamaan Diferensial Biasa Dalam SCILAB $\quad 72$

4.1 Formulasi Masalah Kontrol Optimum Sebagai Masalah Syarat Batas. . . . . 74

4.2 Deskripsi bvode Untuk Menyelesaikan Masalah Syarat Batas Dalam SCILAB 75

5 Prinsip Maksimum Pontryagin Dalam Masalah Kontrol Optimum Stokastik 


\section{PRAKATA}

Buku ini terdiri dari 2 bagian utama. Pada bagian pertama, merupakan catatan perkuliahan Kontrol Optimum yang diampu kedua penulis selama beberapa tahun pada periode 2000-2008. Bagian pertama ini terdiri dari 3 bab, membahas kontrol optimum dan teknik kalkulus variasi sebagai kuliah pengantar ke bidang kontrol optimum bagi yang sudah mengenal persamaan diferensial biasa dan kalkulus variable tunggal. Pada bagian kedua, terdiri atas bab yang memberi pengetahuan bagaimana menyelesaikan masalah kontrol optimum menggunakan metode numerik. Perangkat lunak yang digunakan adalah SCILAB, sehingga disertakan sebuah bab khusus mengenai bagaimana menyusun/menulis program dalam SCILAB. Selain itu, diberikan bab perluasan prinsip Maksimum di dalam Kontrol Optimum ke masalah yang merupakan kajian terkini, yakni Kontrol Optimum Stokastik.

Buku ini didedikasikan kepada mendiang Dr. Sahala M. Nababan, yang memperkenalkan kami bidang ilmu Kontrol Optimum. Penulis pertama, mengucapkan terimakasih kepada AIDAB, yang telah memberi kesempatan berkunjung ke University of Adelaide, South Australia, dimana penulis mendapatkan pemahaman yang lebih dalam dan luas tentang Kontrol Optimum deterministik dan stokastik, dibimbing Dr. John Van Der Hoek. Penulis kedua berterimakasih kepada DAAD yang memberi kesempatan berkunjung ke TU Kaiserslautern, Jerman, dimana penulis berkenalan dengan aliran metode numerik untuk memecahkan permasalahan Kontrol Optimum. Juga berkesempatan mempelajari Quantitative Finance dan

Stochastic Control dari Prof. R. Korn. Serta bantuan penyediaan literatur terkait kontrol optimum yang banyak membantu sehingga tersusunnya buku ini.

Bogor, Oktober 2019 


\section{Bab 1}

\section{Pendahuluan}

\subsection{Masalah Optimisasi Dinamis}

Materi yang disajikan dalam tiga bab pertama buku ini diolah dari berbagai sumber bacaan, terutama dari buku Pierre N.V. Tu ${ }^{1}$.

Masalah pengalokasian optimum dari sumber daya yang terbatas yang memiliki alternatif penggunaannya, baik pada suatu titik waktu tertentu ataupun pada jangka atau periode waktu tertentu, dapat melibatkan optimisasi statis maupun optimisasi dinamis. Dalam kehidupan, seseorang atau suatu institusi dapat saja dihadapkan kepada suatu pilihan mengurangi tingkat konsumsi pada masa kini dalam rangka untuk memenuhi kebutuhan konsumsi yang cukup untuk masa depan. Masalah keputusan yang memperhitungkan waktu seperti di atas, masuk ke dalam kategori masalah optimisasi dinamis.

Suatu alat yang sangat penting dalam menyelesaikan masalah optimisasi dinamis adalah Kalkulus Variasi. Teknik kalkulus variasi ini telah diterapkan dalam masalah ekonomi sejak tahun 1924. Namun demikian, teknik kalkulus variasi memiliki keterbatasan, yang berarti tidak semua masalah dapat diselesaikan dengan teknik kalkulus variasi.

Teknik kontrol optimum yang dikembangkan belakangan, mampu mengatasi keterbatas-

${ }^{1}$ Pierre N.V. TU (1993), Introductory Optimization Dynamics : Optimal Control with Economics and Management Applications, Second Edition, Springer-Verlag, Berlin 
an yang dimiliki oleh teknik kalkulus variasi. Teknik kontrol optimum berkembang pesat sejak ditemukannya teknik program dynamis oleh Richard Bellman pada tahun 1957 dan kemudian diikuti oleh penemuan prinsip maksimum (atau prinsip minimum) oleh Pontryagin pada tahun 1962. Dengan dua penemuan besar tersebut, teknik kontrol optimum yang berkembang mempunyai dua pendekatan : yaitu (1) pendekatan program dinamis, dan (2) pendekatan prinsip maksimum. Dalam kuliah ini, pendekatan yang digunakan adalah pendekatan prinsip maksimum, karena pendekatan ini relatif lebih mudah untuk dipahami.

Pendekatan prinsip maksimum menggunakan teknik yang dikembangkan dalam kalkulus variasi. Oleh karena itu, pembahasan kuliah dimulai dengan pembahasan topik teknik kalkulus variasi. Dengan bekal teknik kalkulus variasi, pembahasan difokuskan pada teknik-teknik kontrol optimum.

Secara sederhana, masalah kontrol optimum dapat didefinisikan sebagai suatu masalah memilih peubah kontrol $u(t)$, yang bergantung pada waktu $t$, diantara semua peubah kontrol yang admissible, yaitu semua kontrol yang membawa sistem dari state awal $x\left(t_{0}\right)$ pada waktu $t_{0}$ kepada state terminal atau state akhir $x(T)$ pada waktu terminal atau wkatu akhir $T$, demikian rupa sehingga memberikan nilai maksimum atau nilai minimum bagi fungsional objektif atau kadang-kadang bisa juga disebut sebagai indeks kinerja.

\subsection{State Sistem Dinamis}

Yang dimaksud dengan state atau keadaan dari suatu sistem dinamis adalah koleksi dari bilangan $x(t) \equiv\left(x_{1}(t), x_{2}(t), \ldots, x_{n}(t)\right)$ yang apabila diberikan suatu nilai pada waktu $t=t_{0}$, maka nilainya akan dapat ditentukan pada waktu $t \geq t_{0}$ melalui pilihan vektor kontrol $u(t)=\left(u_{1}(t), u_{2}(t), \ldots, x_{r}(t)\right)$. Bilangan $x_{i}(t)$ untuk $\left(1 \leq i \leq n, t_{0} \leq t \leq T\right)$ disebut sebagai peubah keadaan atau peubah state, dan ruang keadaan adalah ruang dimensi n yang memuat koordinat $x_{i}(t) \quad(1 \leq i \leq n)$. Dengan cara yang sama, bilangan $u_{i}(t)$ untuk $(1 \leq i \leq$ $\left.r t_{0} \leq t \leq T\right)$ disebut sebagai peubah kontrol atau peubah kendali. Misalnya, $x(t)$ dapat melambangkan peubah ekonomi, seperti GNP, konsumsi, investasi dan kondisi perekonomian lainnya, serta $u(t)$ mewakili peubah kontrol, seperti kebijakan suku bunga, pengeluaran 
pemerintah, suplai uang dan instrumen ekonomi lainnya yang dapat dikendalikan.

Keadaan atau state suatu sistem pada waktu $t$, yang disebut dengan sistem dinamis, direpresentasikan oleh sistem persamaan diferensial dalam hal masalah kontinyu, atau sistem persamaan beda untuk masalah diskret. Misalnya,

$$
\dot{x}(t)=f[x(t), u(t), t]
$$

atau

$$
x(k+1)=f[x(k), u(k), k] .
$$

Sistem dinamis ini sangat beragam bentuknya. Sistem dinamis dapat berbentuk sistem linier dan dapat pula berbentuk sistem tak-linier, juga dapat berbentuk sistem 'autonomous' (sistem tidak memuat waktu $t$ atau $k$ ) atau dapat pula berbentuk sistem 'non-autonomous', dapat pula memiliki koefisien konstanta atau koefisien peubah pada persamaan diferensial atau persamaan beda. Sistem dinamis juga dapat berbentuk sistem deterministik dan juga dapat berbentuk stokastik. Dalam kuliah ini hanya akan dibahas sistem deterministik.

\subsection{Peubah Kontrol}

Sistem dinamis dikontrol atau dikendalikan oleh instrumen atau kontrol yang sesuai. Hanya kontrol yang 'admissible' ( yaitu kontrol yang memenuhi persyaratan yang diberikan) saja yang perlu diperhatikan. Misalnya, jika $u_{i}(t)$ menyatakan proporsi pendapatan nasional yang ditabung untuk membentuk kapital di sektor $i,(i=1,2, \ldots, r)$ maka $0 \leq u_{i}(t) \leq$ $1, \forall i, t$ dan $0 \leq \sum_{1}^{r} u_{i}(t) \leq 1$. Secara umum, kendala fisik ini dinyatakan dengan persyaratan bahwa peubah kontrol harus dipilih dari kumpulan kontrol-kontrol yang admissible, yang dilambangkan dengan $\Omega(u(t))$, artinya, kontrol $u(t) \in \Omega(u(t))$. Untuk ilustrasi di atas,

$$
\Omega(u(t)) \equiv\left\{u_{i}(t): 0 \leq u_{i}(t) \leq 1,0 \leq \sum_{1}^{r} u_{i}(t) \leq 1\right\}
$$

Apabila kontrol $u(t)$ hanya fungsi dari waktu $t$, maka disebut kontrol 'open-loop,' misalnya mengatur mesin cuci untuk berfungsi dalam jangka waktu tertentu. Apabila kontrol $u(t)$, selain fungsi dari waktu $t$ juga merupakan fungsi dari peubah state $x(t)$, yaitu 
$u(t)=u[x(t), t]$, maka disebut kontrol 'closed-loop,' misalnya pengeluaran pemerintah, $u(t)$, merupakan fungsi dari GNP/PDB, $x(t)$, dan waktu pemilu, $t$.

\subsection{Reachability, Controllability dan Observability}

Terdapat tiga istilah penting yang ditemukan dalam pembahasan masalah sistem dinamis dalam teori kontrol optimum, yaitu reachability, controllability dan observability.

Suatu keadaan $x^{1}$ dikatakan dapat dicapai (reachable) dari sebarang keadaan $x^{0}$ pada waktu $t_{0}$ jika kontrol $u_{1}(T) \in \Omega(u(t))$ demikian rupa sehingga $x\left(u_{1}, x^{0}, t^{1}\right)=x^{1}$ untuk waktu $t_{1} \geq t_{0}$. Koleksi dari semua $x^{1}$ tersebut disebut reachable states pada waktu $t$.

Istilah controllability merujuk pada kenyataan bahwa beberapa state terminal $x^{1}$ dapat dicapai dari state awal $x^{0}$ dengan pilihan kontrol $u(t)$ yang tepat, $u(t) \in \Omega(u)$. Jadi, controllability merupakan syarat perlu untuk adanya suatu solusi.

Sementara istilah Observability adalah kemampuan untuk menentukan state awal $x^{0}$ dari observasi data dan output. Output menyatakan hubungan antara peubah state dengan peubah kontrol, misalnya $y(t)=g[x(t), u(t), t]$. Masalah observability hanya muncul jika output tidak dapat diukur secara eksplisit.

\subsection{Fungsional Objektif}

Peubah kontrol $u(t)$ harus dipilih dalam rangka memaksimumkan atau meminimumkan fungsional objektif $J[u(t)]$, (fungsional objektif ini merupakan ukuran kinerja, makanya kadangkadang juga disebut dengan indeks performance atau kinerja)

$$
J[u(t)]=\int_{t_{0}}^{T} f_{0}(x(t), u(t), t) d t
$$

dengan $f_{0}$ adalah fungsi bernilai riel. Jika fungsi

$$
f_{0}(x, u, t)=\pi(x, p) e^{-r t}, \text { atau } f_{0}=u(c) e^{-r t}
$$


maka fungsional $J$ merupakan nilai kini (present value) dari profit $\pi$ atau utilitas konsumsi yang terdiskon pada tingkat diskon $r$.

Secara umum, terdapat tiga alternatif cara untuk menyajikan formulasi fungsional objektif ( 1.3), yaitu :

1. (Formulasi Bolza) Formulasi fungsional objektif bentuk Bolza merupakan formulasi yang lebih umum. Formulasi ini dituliskan dalam bentuk

$$
J[u(t)]=S[x(T), T]+\int_{t_{0}}^{T} f_{0}(x(t), u(t), t) d t
$$

dengan $f_{0}$ dan $S$ adalah fungsi yang kontinu dan dapat diturunkan. Fungsi $S[x(T), T]$ dikenal dengan fungsi 'scrap value' atau nilai sisa pada waktu terminal $T$.

2. (Formulasi Lagrange ) Formulasi Lagrange merupakan bentuk khusus dari ( 1.4), dengan $S[x(T), T]=0$, yaitu

$$
J[u(t)]=\int_{t_{0}}^{T} f(x(t), u(t), t) d t
$$

3. (Formulasi Mayer) Formulasi Mayer ini juga merupakan bentuk khusus dari ( 1.4), dengan $f(x(t), u(t), t)=0$, yaitu

$$
J[u(t)]=S[x(T), T]
$$

Dengan pendefinisian kembali peubah-peubahnya, maka ketiga alternatif penulisan di atas adalah ekivalen. Misalnya, formulasi Bolza dapat dikonversikan menjadi formulasi Mayer dengan mendefinisikan peubah tambahan $x_{n+1}(t)$ sebagai

$$
x_{n+1}(t)=\int_{t_{0}}^{t} f(x, u, \tau) d \tau, \quad x_{n+1}\left(t_{0}\right)=0
$$

akan menghasilkan $J=x_{n+1}(t)+S[x(T), T]$.

\subsection{Kalkulus Variasi dan Kontrol Optimum}

Dalam masalah kalkulus variasi dalam bentuk baku, tujuannya adalah untuk memaksimumkan atau meminimumkan fungsional objektif

$$
J[x(t)]=\int_{0}^{T} f_{0}(x(t), \dot{x}(t), t) d t
$$


dengan fungsi kendala atau tanpa fungsi kendala; fungsi kendala dapat berupa persamaan diferensial atau dapat juga berupa persamaan aljabar. Misalnya, persamaan diferensial $\dot{x}=f(x(t), \dot{x}(t), t)$.

Sementara itu, dalam bentuk bakunya, kontrol optimum mempunyai tujuan untuk memaksimumkan atau meminimumkan fungsional objektif

$$
J[u(t)]=\int_{0}^{T} f_{0}(x(t), u(t), t) d t
$$

dengan kendala persamaan diferensial $\dot{x}=f(x(t), u(t), t)$. Apabila $\dot{x}(t)=u(t)$, maka masalah kalkulus variasi sama saja dengan masalah kontrol optimum. Kenyataannya, masalah kontrol optimum dapat diselesaikan dengan teknik kalkulus variasi (persamaan Euler) dan sebaliknya prinsip Maksimum Pontryagin yang merupakan syarat perlu untuk adanya kontrol optimum dapat diperlakukan sebagai pengembangan dari kalkulus variasi. 


\section{Bab 2}

\section{Kalkulus Variasi}

\subsection{Pendahuluan}

Kalkulus variasi merupakan cabang ilmu matematika yang berkaitan dengan pengoptimuman fungsional. Cabang ilmu ini telah mulai berkembang sejak ditemukannya masalah isoperimetris untuk pertamakalinya sekitar tahun 850 B.C. Akan tetapi, progres yang signifikan dalam cabang ilmu ini baru terjadi sekitar penghujung abad 17 melalui penemuan masalah brachitoschrone, yang solusinya diberikan oleh Newton, de l'Hospital, John dan Jacob Bernoulli pada tahun 1696.

Dalam bidang ekonomi, penggunaan kalkulus variasi sudah ada sejak tahun 1920an, melalui karya Evans (1924 dan 1930), Ramsey (1928) dan Hotelling (1931). Evans dan Roos berupaya untuk menemukan harga optimum untuk keseluruhan periode perencanaan, seperti memaksimumkan fungsional keuntungan dari pelaku usaha monopoli. Sedangkan Ramsey ingin menemukan program penghematan yang meminimumkan perbedaan tingkat utilitas. Masalah penghematan optimum ini, yang memuat sumber inspirasi dalam teori pertumbuhan ekonomi yang optimum, diselesaikan dengan teknik kalkulus variasi. Sementara itu Hotelling menggunakan teknik kalkulus variasi dalam masalah penambangan optimum dari sumber daya alam. 


\section{$2.2 \quad$ Fungsional Dan Variasi}

Fungsional memainkan peranan penting dalam kalkulus variasi. Fungsional, misalnya norm $x=\|x\|$, atau misalnya $J(x)=\int_{a}^{b} x(t) d t$, adalah suatu aturan yang mengkaitkan tiap fungsi $x \in R$ dengan suatu bilangan tunggal $\|x\|$ atau $J(x)$. Terdapat analogi antara fungsi dengan fungsional. Argumen dari fungsi merupakan peubah, misalnya $x=x(t)$, sedangkan argumen dari fungsional merupakan fungsi, misalnya $J(x(t))=\int_{a}^{b} x(t) d t$. Apabila fungsi secara lengkap dapat ditentukan manakala peubahnya diberikan nilai-nilai tertentu, maka suatu fungsional secara lengkap ditentukan oleh pilihan fungsi tertentu dari sekumpulan fungsi yang admissible.

Increment atau kenaikan dari argumen suatu fungsi adalah $d t=t-t^{*}$, sementara itu, increment dari argumen fungsional, yang kita sebut dengan variasi dan dengan menggunakan notasi $\delta x$ merupakan selisih $\delta x=x(t)-x\left(t^{*}\right)$. Dalam mempelajari fungsi, kita tertarik untuk menemukan titik yang memberikan ekstremum untuk fungsi, sedangkan dalam pembahasan fungsional kita tertarik untuk menemukan fungsi yang memberikan ekstremum untuk fungsional.

Variasi dari fungsional $J(x)$ adalah $\triangle J(x)=J(x+\delta x)-J(x)$. Dengan mengambil $\delta x=h$ sebarang fungsi, maka dengan menggunakan perluasan deret Taylor, maka diperoleh

$$
\begin{aligned}
J(x+\delta x) & =\int_{0}^{T} f(x+h, \dot{x}+\dot{h}, t) d t \\
& =\int_{0}^{T} f(x, h, t) d t+\int_{0}^{T}\left(h f_{x}+\dot{h} f_{\dot{x}}\right) d t \\
& +\int_{0}^{T}\left(h^{2} f_{x x}+2 h \dot{h} f_{x \dot{x}}+f_{\dot{x} \dot{x}} \dot{h}^{2}\right) d t+O\|h\|^{2} \\
& =J(x)+\int_{0}^{T} f(x, h, t) d t+\int_{0}^{T}\left(h^{2} f_{x x}+2 h \dot{h} f_{x \dot{x}}+f_{\dot{x} \dot{x}} \dot{h}^{2}\right) d t+O\|h\|^{2},
\end{aligned}
$$

sehingga diperoleh

$$
\begin{aligned}
\triangle J(h) & =J(x+h)-J(x) \\
& =\phi(h)+Q(h)+O\|h\|^{2} \\
& =\delta J(h)+\delta^{2} J(h)+O\|h\|^{2}
\end{aligned}
$$

dengan $\phi(h)$ merupakan suku-suku linear dalam deret Taylor yang kita sebut dengan variasi 
pertama $\delta J(h)$ dan $Q(h)$ adalah suku-suku kuadrat yang mengindikasikan variasi kedua $\delta^{2} J(h)$ dan $O\|h\|^{2} \rightarrow 0$ untuk $h \rightarrow 0$.

Definisi 2.1 Fungsional $J(x)$ dikatakan mencapai maksimum (minimum) lokal atau relatif sepanjang $x^{*}(t)$ apabila $\triangle J\left(x^{*}\right) \geq 0 \quad(\leq 0)$, yaitu $J\left(x^{*}\right) \geq J(x) \quad\left(J\left(x^{*}\right) \leq J(x)\right)$ untuk semua fungsi-fungsi yang cukup dekat dengan $x^{*}$. Fungsional $J(x)$ dikatakan mencapai maksimum (minimum) global sepanjang $x^{*}(t)$ apabila $\triangle J\left(x^{*}\right) \geq 0 \quad(\leq 0)$, yaitu $J\left(x^{*}\right) \geq J(x) \quad\left(J\left(x^{*}\right) \leq J(x)\right)$ untuk semua fungsi $x(t) \neq x^{*}(t)$.

\subsection{Syarat Perlu Untuk Optimum : Persamaan Euler}

Misalkan $C[0, T]$ menyatakan kelas semua fungsi kontinu yang terdefinisi pada selang $[0, T]$ dan $C^{i}[0, T]$ menyatakan semua fungsi yang didefinisikan di selang $[0, T]$ dan memiliki turunan ke-i yang kontinu. Perhatikan masalah variasi dalam bentuk sederhana berikut:

$$
J(x)=\int_{0}^{T} f(x, \dot{x}, t) d t
$$

dengan titik $A(0, x(0))$ dan $B(T, x(T))$ adalah dua titik ujung tetap, $f(x, \dot{x}, t), \quad x(t) \in$ $C^{2}[0, T]$ dan $\dot{x} \equiv d x / d t$ dan $x$ adalah fungsi bernilai skalar. Masalah kalkulus variasi adalah memilih fungsi $x^{*}(t)$ diantara fungsi-fungsi admissible, yaitu semua fungsi $x(t) \in C^{2}[0, T]$ yang memiliki titik awal di A dan titik akhir di B yang memberikan nilai maksimum atau nilai minimum untuk fungsional $J(x)$.

Syarat perlu untuk adanya ekstremum adalah $\delta J(x)=0$. Misalkan

$$
\delta J(x)=\int_{0}^{T} g(t) h(t) d t
$$

dengan $g(t) \in C[0, T]$ dan $h(t)$ sebarang fungsi yang memenuhi $h(0)=h(T)=0$.

Lema 2.1 ( Lema Dasar) Misal $g(t) \in C[0, T]$ dan $S$ himpunan semua fungsi $h(t)$ kontinu dan dapat diturunkan di $[0, T]$ dan $h(0)=h(T)=0$ dengan $T$ adalah tetap. Jika

$$
\int_{0}^{T} g(t) h(t) d t=0
$$

untuk semua $h \in S$, maka $g(t)=0$ untuk semua $t \in[0, T]$. 
Bukti : Misalkan $g(t) \neq 0$, yaitu $g(t)>0$, pada $[0, T]$. Dengan sifat kekontinuan, maka $g(t) \neq 0$ untuk suatu selang $[a, b] \in[0, T]$, dengan $0<a<b<T$. Misal $h(t) \equiv(t-a)(b-t)$ untuk $t \in[a, b]$ dan $h(t)=0, \forall t \ni[a, b]$. Jelas bahwa $h(t)$ memenuhi persyaratan lema. Tetapi, $\int_{0}^{T} g(t)(t-a)(b-t) d t \neq 0$. Suatu kontradiksi. Dengan demikian, haruslah $g(t)=0$.

Teorema 2.1 Misalkan $J(x)=\int_{0}^{T} f(x, \dot{x}, t) d t$ didefinisikan pada $C^{\prime}[0, T]$ dan memenuhi syarat batas $x(0)=x_{0}, \quad x(T)=x_{T}$. Maka syarat perlu bagi $J(x)$ untuk memiliki ekstremum adalah fungsi $x(t)$ memenuhi persamaan Euler:

$$
f_{x}-\frac{d}{d t} f_{\dot{x}}=0
$$

atau dituliskan dalam bentuk penuh, yang disebut dengan persamaan Euler-Lagrange:

$$
f_{x}-f_{\dot{x} t}-f_{x \dot{x}} \dot{x}-f_{\dot{x} \dot{x}} \ddot{x}=0 .
$$

Bukti : Syarat perlu untuk ekstremum adalah $\delta J(x)=0$, yaitu

$$
\delta J=\int_{0}^{T}\left[f_{x}(x, \dot{x}, t) h+f_{\dot{x}}(x, \dot{x}, t) \dot{h}\right] d t=0
$$

dengan $f_{x} \equiv \partial f(x, \dot{x}, t) / \partial x, \quad f_{\dot{x}} \equiv \partial f(x, \dot{x}, t) / \partial \dot{x}$ dan $h(t)$ adalah fungsi 'displacement' merupakan fungsi kontinu sebarang dan bersifat $h(0)=0=h(T)$. Dengan melakukan integrasi bagian terhadap suku kedua, diperoleh

$$
\begin{aligned}
\int_{0}^{T} \dot{h} f_{\dot{x}} & =\left.h f_{\dot{x}}\right|_{0} ^{T}-\int_{0}^{T}\left(\frac{d}{d t} f_{\dot{x}}\right) h d t \\
& =0-\int_{0}^{T}\left(\frac{d}{d t} f_{\dot{x}}\right) h d t
\end{aligned}
$$

karena $h(0)=0=h(T)$. Sehingga diperoleh

$$
\delta J=\int_{0}^{T}\left(f_{x}-\frac{d}{d t} f_{\dot{x}}\right) h d t=0
$$

yang pada gilirannya dengan Lema Dasar memberikan persamaan Euler :

$$
f_{x}-\frac{d}{d t} f_{\dot{x}}=0
$$


Contoh 2.1 Tentukan ekstremum dari $\int_{0}^{1}\left(a \dot{x}^{2}+b t\right) d t$, diberikan $x(0)=0, \quad x(1)=2, \quad a \neq$ 0 .

\section{Solusi :}

Fungsi integran adalah dalam bentuk $f(\dot{x})=a \dot{x}^{2}+b t$. Persamaan Euler memberikan $d / d t(2 a \dot{x})=$ 0 , atau $\ddot{x}=0$, karena $a \neq 0$. Lakukan integrasi, maka diperoleh $\dot{x}(t)=c \quad$ dan $x(t)=c t+d$, dengan $c$ dan $d$ merupakan konstanta yang akan ditentukan nilainya dari syarat batas $x(0)=0 \quad$ dan $x(1)=2$. Akhirnya diperoleh solusi yang merupakan garis lurus, yaitu $x(t)=2 t$.

Contoh 2.2 Tentukan ekstremum dari $\int_{0}^{10} f(x, \dot{x}, t) d t$, dengan fungsional objektif didefinisikan oleh $f(x, \dot{x}, t) \equiv a \dot{x}^{2}+b x$, dan persyaratan pada kedua titik ujung diberikan oleh $x(0)=1$ dan $x(10)=5$.

\section{Solusi :}

Fungsi $f(x, \dot{x}, t)=a \dot{x}^{2}+b x$. Maka persamaan Euler $f_{x}-\frac{d}{d t} f_{\dot{x}}=0$ akan memberikan $b-$ $\frac{d}{d t} 2 a \dot{x}=0$. Yang terakhir ini akan memberikan $\ddot{x}=b /(2 a)$. Dengan melakukan integrasi dua kali, maka akan diperoleh solusi umum

$$
x(t)=\frac{b}{4 a} t^{2}+k_{1} t+k_{2} .
$$

Dengan menggunakan $x(0)=1$ dan $x(10)=5$, diperoleh $k_{1}=25 b / a, \quad k_{2}=1$, sehingga diperoleh solusi khusus

$$
x(t)=\frac{b}{4 a} t^{2}+25 b / a t+1
$$

Contoh 2.3 Seorang produsen merencanakan produksi dalam rentang waktu [0,1]. Tingkat output pada waktu $t=0$ adalah nol dan tingkat output pada waktu terminal $t=1$ adalah sebesar 10 satuan produksi. Tentukan tingkat output optimum $x(t)$ apabila produsen dihadapkan pada harga pasar stabil, $p=4$ satuan moneter dan fungsi ongkos total $\dot{x}^{2}+x^{2}$ yang mengalami diskon pada tingkat suku bunga pasar $r=0,2$.

\section{Solusi :}

Fungsional objektif yang akan dimaksimumkan oleh produsen dirumuskan dalam bentuk

$$
J(x)=\int_{0}^{1} e^{-0,2 t}\left[4 x-\left(\dot{x}^{2}+x^{2}\right)\right] d t, \quad x(0)=0, \quad x(1)=10 .
$$


Persamaan Euler memberikan

$$
f_{x}-\frac{d}{d t} f_{\dot{x}}=e^{-0,2 t}(4-2 x)-\frac{d}{d t} e^{-0,2 t}(-2 \dot{x})=0,
$$

yaitu menghasilkan $\ddot{x}-0,2 \dot{x}-x=-2$. Solusi dari persamaan diferensial ini adalah

$$
x(t)=k_{1} e^{\lambda_{1} t}+k_{2} e^{\lambda_{2} t}+2
$$

dengan $\lambda_{1}, \quad \lambda_{2}=0,1 \pm \sqrt{0,01+1}$ merupakan akar dari persamaan karakteristik

$$
\lambda^{2}-0,2 \lambda-1=0
$$

dengan 2 merupakan solusi dari persamaan diferensial tak homogen. Konstanta $k_{1}$ dan $k_{2}$ adalah konstanta integrasi yang dapat ditentukan dari syarat batas $x(0)=0$ dan $x(1)=10$. Akhirnya diperoleh solusi khusus, yaitu

$$
x(t)=3,358 e^{1,105 t}-5,358 e^{-0,905 t}+2 .
$$

\subsection{Persamaan Euler Yang Lebih Umum}

\subsubsection{Kasus Peubah banyak}

Perhatikan fungsional objektif $J(x)=\int_{0}^{T} f(x, \dot{x}, t) d t$, dengan $x=\left(x_{1}, x_{2}, \ldots, x_{n}\right)$ dan $\dot{x}=$ $\left(\dot{x_{1}}, \dot{x_{2}}, \ldots, \dot{x_{n}}\right)$. Maka, dengan melakukan integrasi bagian terhadap $\delta J$ dan dengan menggunakan $h_{i}(0)=0=h_{i}(T), \quad \forall i$ diperoleh :

$$
\begin{aligned}
\delta J & =\int_{0}^{T}\left(\sum_{1}^{n} h_{i} f_{x_{i}}+\sum_{1}^{n} \dot{h_{i}} f_{\dot{x}_{i}}\right) d t=0 \\
& =\int_{0}^{T}\left(f_{x_{i}}-\frac{d}{d t} f_{\dot{x}_{i}}\right) h_{i} d t, \quad \forall h_{i}(t) .
\end{aligned}
$$

Dengan menggunakan Lema Dasar, akan menghasilkan persamaan Euler

$$
f_{x_{i}}-\frac{d}{d t} f_{\dot{x_{i}}}=0, \quad \forall i
$$

atau dalam bentuk penuh, persamaan Euler-Lagrange

$$
f_{x_{i}}-f_{\dot{x_{i} t}}-f_{x_{i} \dot{x_{i}}} \dot{x_{i}}-f_{\dot{x_{i}} \dot{x_{i}}} \ddot{x}_{i}=0, \quad(1 \leq i \leq n) .
$$


Contoh 2.4 Tentukan ekstremum untuk $\int_{0}^{10}\left({\dot{x_{1}}}^{2}+{\dot{x_{2}}}^{2}+e^{t}\right) d t$ dengan syarat batas $x_{1}(0)=$ $1, \quad x_{1}(10)=11$ dan $x_{2}(0)=2, \quad x_{2}(10)=6$.

Solusi : Fungsi integran untuk masalah di atas adalah dalam bentuk $f\left(x_{1}, x_{2}, \dot{x_{1}}, \dot{x_{2}}, t\right)=$ ${\dot{x_{1}}}^{2}+{\dot{x_{2}}}^{2}+e^{t}$. Persamaan Euler memberikan

$$
f_{x_{i}}-\frac{d}{d t} f_{\dot{x}_{i}}=0-\frac{d}{d t} 2 \dot{x}_{i} \quad(i=1,2)
$$

yaitu $\ddot{x}_{i}=0, \quad \dot{x}_{i}=k_{i}$, dengan solusinya adalah persamaan linier $x_{i}(t)=k_{i}(t)+c_{i}, \quad(i=1,2)$. Dengan menggunakan syarat batas, maka diperoleh solusi khusus

$$
x_{1}(t)=t+1, \quad x_{2}(t)=0,4 t+2 .
$$

\subsubsection{Kasus Fungsi $f$ Memuat Turunan ke-n}

Perhatikan fungsional objektif dengan fungsi $f$ memuat turunan ke- $n, \quad(n \geq 1)$

$$
J(x)=\int_{0}^{T} f\left(t, x, \dot{x}, \ddot{x}, \ldots, x^{n}\right) d t
$$

dengan titik ujung tetap $x^{i}(0)=x_{0}{ }^{i}$, dan $x^{i}(T)=x_{T}{ }^{i}$ berturut-turut memberikan persyaratan $h(0)=\dot{h}(0)=\ldots=h^{n}(0)=0$, dan $h(T)=0=\dot{h}(T)=\ldots=h^{n}(T)$. Syarat perlu untuk adanya ekstremum bagi $J(x)$ adalah

$$
\delta J=\int_{0}^{T}\left(f_{x} h+f_{\dot{x}} \dot{h}+f_{\ddot{x}} \ddot{h}+\ldots+f_{x^{n}} h^{n}\right) d t=0 .
$$

Integrasi bagian terhadap suku kedua integran menghasilkan

$$
\begin{aligned}
\int_{0}^{T} f_{\dot{x}} \dot{h} d t & =\left.f_{\dot{x}} h\right|_{0} ^{T}-\int_{0}^{T}\left(\frac{d}{d t} f_{\dot{x}}\right) h d t \\
& =0-\int_{0}^{T}\left(\frac{d}{d t} f_{\dot{x}}\right) h d t
\end{aligned}
$$

karena $h(0)=0=h(T)$.

Integrasi bagian terhadap suku ketiga integran, dan mengulangi integrasi bagian sampai diperoleh suku yang memuat perkalian dengan fungsi $h$, diperoleh :

$$
\int_{0}^{T} f_{\ddot{x}} \ddot{h} d t=\left.f_{\ddot{x}} \dot{h}\right|_{0} ^{T}-\int_{0}^{T} \dot{h} \frac{d}{d t} f_{\ddot{x}} d t
$$




$$
\begin{aligned}
& =0-\left.\frac{d}{d t} f_{\ddot{x}} h\right|_{0} ^{T}+\int_{0}^{T} h \frac{d^{2}}{d t^{2}} f_{\ddot{x}} d t \\
& =0-0+\int_{0}^{T} h \frac{d^{2}}{d t^{2}} f_{\ddot{x}} d t .
\end{aligned}
$$

Penggunaan integrasi bagian secara berulang terhadap suku-suku berikutnya dan dengan menggunakan syarat $h(0)=0=\dot{h}(0)=\ddot{h}(0)=\ldots=h^{n}(0)$ dan $h(T)=0=\dot{h}(T)=\ddot{h}(T)=$ $\ldots=h^{n}(T)$, menghasilkan

$$
\delta J=\int_{0}^{T}\left(f_{x}-\frac{d}{d t} f_{\dot{x}}+\frac{d^{2}}{d t^{2}} f_{\ddot{x}}+\ldots+(-1)^{n} \frac{d^{n}}{d t^{n}} f_{x^{n}}\right) h d t=0 .
$$

Dengan Lema Dasar, maka diperoleh persamaan Euler-Poisson :

$$
f_{x}-\frac{d}{d t} f_{\dot{x}}+\frac{d^{2}}{d t^{2}} f_{\ddot{x}}+\ldots+(-1)^{n} \frac{d^{n}}{d t^{n}} f_{x^{n}}=0 .
$$

Contoh 2.5 Tentukan ekstremum dari $\int_{0}^{1}\left(\ddot{x}^{2}+\dot{x}+a t^{2}\right) d t$, dengan $x(0)=0, \dot{x}(0)=1$, $x(1)=1$, dan $\dot{x}(1)=1$.

Solusi : $\quad$ Fungsi objektif adalah $f(\ddot{x}, \dot{x}, x, t)=\ddot{x}^{2}+\dot{x}+a t^{2}$. Persamaan Euler-Poisson memberikan

$$
f_{x}-\frac{d}{d t} f_{\dot{x}}+\frac{d^{2}}{d t^{2}} f_{\ddot{x}}=0-\frac{d}{d t} 1+\frac{d^{2}}{d t^{2}} 2 \ddot{x}=0,
$$

yang memberikan $x^{(4)}=0$. Dengan melakukan integrasi secara berulang, maka diperoleh solusi umum

$$
x(t)=\frac{k_{1} t^{3}}{6}+\frac{k_{2} t^{2}}{2}+k_{3} t+k_{4},
$$

dengan konstanta integrasi $k_{1}, \quad k_{2}, \quad k_{3}$ dan $k_{4}$ ditentukan dari syarat batas yang diberikan. Maka akan diperoleh solusi atau ekstremal $x(t)=t$.

\subsection{Kasus Khusus Persamaan Euler}

\subsubsection{Fungsi $f$ Tidak Memuat $x$}

Fungsional objektif adalah dalam bentuk

$$
J(x)=\int_{0}^{T} f(\dot{x}, t) d t
$$


dengan $f$ tidak memuat $x$ secara eksplisit. Untuk kasus seperti ini, Persamaan Euler akan berbentuk $d / d t f_{\dot{x}}=0$. Ini berarti bahwa $f_{\dot{x}}=k$, dengan $k$ merupakan suatu konstanta. Ini merupakan persamaan diferensial ordo-1, dengan $k$ merupakan konstanta sebarang. Solusinya diperoleh dengan melakukan integrasi $\dot{x}$.

Jika $f$ bergantung hanya pada $\dot{x}$, maka persamaan Euler menjadi

$$
\frac{d}{d t} f_{\dot{x}}=f_{\dot{x} \dot{x}} \ddot{x}=0 .
$$

Hal ini terjadi hanya jika $\ddot{x}=0$, yang memberikan $\dot{x}=c$, dan $x(t)=c_{1} t+c_{2}$, atau terjadi jika $f_{\dot{x} \dot{x}}=0$. Jika $f_{\dot{x} \dot{x}}$ memiliki akar nyata, dalam hal ini $\dot{x}(t)=c$, maka solusinya adalah

$$
x(t)=c_{3} t+c_{4}
$$

Terlihat bahwa manapun yang berlaku, solusi dari persamaan Euler berbentuk persamaan garis lurus $x(t)=a t+b$.

Contoh 2.6 Tentukan ekstremum untuk fungsional objektif $J(x)=\int_{0}^{1}\left(t \dot{x}+\dot{x}^{2}\right) d t$ dengan syarat batas $x(0)=1, x(1)=1$.

Solusi : $\quad$ Karena fungsi $f(x, \dot{x}, t)=t \dot{x}+\dot{x}^{2}$ tidak memuat $x$, maka persamaan Euler menghasilkan $d / d t\left(f_{\dot{x}}\right)=t+2 \dot{x}$ yang memberikan $t+2 \dot{x}=$ konstanta, atau $\dot{x}=-1 / 2 t+k_{1}$. Dengan melakukan integrasi secara langsung, diperoleh solusi umum :

$$
x(t)=-\frac{1}{4} t^{2}+k_{1} t+k_{2}
$$

Dengan menggunakan syarat batas, diperoleh $k_{1}=1 / 4, \quad k_{2}=1$, sehingga diperoleh solusi khusus :

$$
x(t)=-\frac{1}{4} t^{2}+\frac{1}{4} t+1 .
$$

\subsubsection{Fungsi $f$ Tidak Memuat $t$}

Fungsional objektif dalam bentuk

$$
J(x)=\int_{0}^{T} f(x, \dot{x}) d t .
$$


Persamaan Euler memberikan

$$
f_{x}-\frac{d}{d t} f_{\dot{x}}=f_{x}-f_{\dot{x} x} \dot{x}-f_{\dot{x} \dot{x}} \ddot{x}
$$

Kalikan dengan $\dot{x}$ memberikan

$$
f_{x} \dot{x}-f_{\dot{x} x} \dot{x}^{2}-f_{\dot{x} \dot{x}} \dot{x} \ddot{x} \equiv \frac{d}{d t}\left(f-\dot{x} f_{\dot{x}}\right)=0 .
$$

Ini berarti bahwa $f-\dot{x} f_{\dot{x}}=k$.

\subsubsection{Fungsi $f$ Tidak Memuat $\dot{x}$}

Fungsional objektif dalam bentuk

$$
J(x)=\int_{0}^{T} f(x, t) d t
$$

Persamaan Euler memberikan $f_{x}=0$. Ini bukan persamaan diferensial, tetapi secara umum merupakan persamaan aljabar tak linier. Umumnya, syarat batas tidak dapat dipenuhi, karena tidak ada konstanta integrasi. Dengan kata lain, solusi ada hanya jika kurva $x=x(t)$ melewati titik batas.

\subsection{Masalah Variasi Dengan Kendala}

Dalam masalah kalkulus variasi, kadangkala terdapat kendala tambahan yang disebabkan oleh kondisi fisik dari permasalahan. Ekstremum dari fungsional didefinisikan dalam kerangka kendala tersebut yang sering dikenal dengan sebutan ekstremum berkendala. Implikasi yang sangat penting dari kendala tersebut adalah variasi $\delta x_{i}$ bukan lagi merupakan sebarang sehingga Lema Dasar tidak dapat diterapkan. Untuk masalah seperti ini digunakan metoda substitusi atau yang lebih dikenal dengan sebutan pengali Lagrange. Akan dibahas tiga jenis kendala, yaitu kendala titik, kendala persamaan diferensial dan kendala isoperimetric. 


\subsubsection{Kendala Titik Dan Kendala Persamaan Diferensial}

Perhatikan masalah menentukan ekstremum fungsional

$$
\int_{0}^{T} f(x, \dot{x}, t) d t
$$

terhadap kendala

$$
g_{i}(x, \dot{x}, t)=0, \quad(1 \leq i \leq r<n)
$$

dengan $x$ merupakan vektor dimensi-n dan $\dot{x}$ merupakan turunannya terhadap waktu $t$, serta $f(x, \dot{x}, t)$ adalah fungsi bernilai skalar. Persamaan $g_{i}(x, \dot{x}, t)=0$ disebut dengan kendala persamaan diferensial. Apabila $g_{i}(x, \dot{x}, t)$ tidak memuat $\dot{x}$ maka $g_{i}(x, t)=0$ disebut kendala titik.

Definisikan fungsi Lagrange $L$ sebagai berikut :

$$
L \equiv f(x, \dot{x}, t)+p \cdot g_{i}(x, \dot{x}, t)
$$

atau dalam bentuk skalar

$$
L \equiv f(x, \dot{x}, t)+\sum_{i=1}^{r} p_{i} g_{i}(x, \dot{x}, t)
$$

dengan $x(0)=x_{0}$ dan $x(T)=x_{T}$. Definisikan fungsional objektif yang diperluas, $J_{a}$ sebagai berikut

$$
J_{a} \equiv \int_{0}^{T} L(x, \dot{x}, p, t) d t
$$

Variasi $\delta J_{a}$ adalah

$$
\begin{aligned}
\delta J_{a} & =\int_{0}^{T}\left(L_{x} \delta x+L_{\dot{x}} \delta \dot{x}+L_{p} \delta p\right) d t \\
& =\int_{0}^{T}\left[\left(L_{x}-\frac{d}{d t} L_{\dot{x}}\right) \delta x+L_{p} \delta p\right] d t
\end{aligned}
$$

Syarat perlu untuk adanya ekstremum adalah $\delta J_{a}=0$ dan dipenuhinya kendala yang ada. In berarti bahwa persamaan Euler berikut harus dipenuhi, yaitu :

$$
\begin{aligned}
& L_{x}-\frac{d}{d t} L_{\dot{x}}=0, \\
& L_{p}-\frac{d}{d t} L_{\dot{p}}=0,
\end{aligned}
$$

dengan $L_{x} \equiv f_{x}+g_{x} p$, dan $L_{\dot{x}} \equiv f_{\dot{x}}+g_{\dot{x}} p$, untuk kendala diferensial, dan $L_{\dot{x}} \equiv f_{\dot{x}}$ untuk kendala titik. Karena $L_{\dot{p}}=0$ maka diperoleh $L_{p}=g=0$. Solusi, atau ekstremal akan diperoleh dengan menyelesaikan persamaan diferensial yang diberikan oleh persamaan Euler. 


\subsubsection{Kendala Isoperimetris}

Pada awalnya, masalah isoperimetric adalah masalah mencari kurva dengan panjangnya $l$ yang melingkari daerah terbesar. Dalam perspektif yang lebih luas, masalah isoperimetric adalah masalah variasi dengan kendala yang diberikan dalam bentuk integral tentu yang mempunyai nilai tertentu. Secara matematis, masalah isoperimetric adalah masalah menentukan ekstremum dari fungsional objektif

$$
J(x)=\int_{0}^{T} f(x, \dot{x}, t) d t
$$

terhadap kendala

$$
x_{i}(0)=x_{i 0}, \quad x_{i}(T)=x_{i T}, \quad(1 \leq i \leq n)
$$

dan

$$
\int_{0}^{T} g_{i}(x, \dot{x}, t) d t=l_{i}, \quad(1 \leq i \leq r<n)
$$

dengan $l_{i}$ merupakan konstanta. Kendala ( 2.24) dinamakan kendala isoperimetric.

Definisikan fungsi baru $y_{i}(t) \equiv \int_{0}^{t} g_{i}(x, \dot{x}, t) d t$, dengan $y_{i}(0)=0$, dan $y_{i}(T)=l_{i}, \quad(1 \leq$ $i \leq r<n)$. Dengan menurunkan $y_{i}(t)$ terhadap waktu $t$ maka diperoleh $\dot{y}_{i}(t)=g_{i}(x, \dot{x}, t)$ atau $g_{i}-\dot{y}_{i}=0$. Dengan cara ini, kendala isoperimetric sudah ditransfer menjadi kendala persamaan diferensial. Jadi, untuk menyelesaikannya, digunakan metode pengali Lagrange. Fungsional yang diperluas diberikan oleh

$$
\begin{aligned}
J_{a} & \equiv \int_{0}^{T} F(x, \dot{x}, t) d t \\
& =\int_{0}^{T}\left[f(x, \dot{x}, t)+\sum_{i=1}^{r} p_{i}(t)\left(g_{i}-\dot{y}_{i}\right)\right] d t
\end{aligned}
$$

Persamaan Euler memberikan

$$
\begin{array}{ll}
\frac{\partial F}{\partial x_{j}}-\frac{d}{d t}\left(\frac{\partial F}{\partial \dot{x}_{j}}\right)=0 & (1 \leq i \leq n) \\
\frac{\partial F}{\partial y_{j}}-\frac{d}{d t}\left(\frac{\partial F}{\partial \dot{y}_{j}}\right)=0 & (1 \leq i \leq r)
\end{array}
$$

Selanjutnya, solusi atau ekstremum akan diperoleh dengan menentukan solusi dari persamaan diferensial yang dibentuk oleh persamaan Euler. 
Contoh 2.7 Maksimumkan $J(x)=\int_{0}^{T} \dot{x}^{2} d t$,

terhadap kendala $x(0)=x_{0}, \quad x(T)=x_{T}$ dengan $T$ diberikan, dan

$$
\int_{0}^{T}(1+x) d t=l, \quad(\text { k konstanta })
$$

Solusi : Definisikan fungsi $y(t)$ dengan

$$
y(t) \equiv \int_{0}^{t}(1+x) d t \quad \text { dengan } \quad y(0)=0, \quad y(T)=l .
$$

Maka $\dot{y}(t)=1+x(t)$, dan fungsi Lagrange diberikan oleh $L=\dot{x}^{2}+p(1+x-\dot{y})$. Sehingga persamaan Euler memberikan $2 \ddot{x}=p$, dengan solusinya adalah

$$
x(t)=\frac{p}{4} t^{2}+a t+b .
$$

Syarat batas memberikan

$$
\begin{aligned}
x(0) & =x_{0}=b \\
x(T) & =x_{T}=\frac{p}{4} T^{2}+a T+b \\
l & =\int_{0}^{T}(1+x) d t=\int_{0}\left(1+\frac{p}{4} t^{2}+a t+b\right) d t
\end{aligned}
$$

Persamaan yang terakhir ini memberikan

$$
p=\frac{12}{T^{3}}\left(l-\frac{a}{2} T^{2}-(1+b) T\right) .
$$

Persamaan di atas akan memberikan kontanta $a, b$ dan $p$.

\subsection{Syarat Batas Dalam Masalah Variasi}

\subsubsection{Dua Titik Ujung Tetap Dan Syarat Batas Natural}

Perhatikan fungsional objektif

$$
J(x)=\int_{0}^{T} f(x, \dot{x}, t) d t
$$


Syarat perlu terdapatnya ekstremum adalah $\delta J=0$, dengan

$$
\begin{aligned}
\delta J & =\int_{0}^{T}\left(f_{x} h+f_{\dot{x}} \dot{h}\right) d t \\
& =\int_{0}^{T}\left(f_{x}-\frac{d}{d t} f_{\dot{x}}\right) h d t+\left.h f_{\dot{x}}\right|_{0} ^{T}=0 .
\end{aligned}
$$

Karena persamaan Euler harus dipenuhi, yaitu $f_{x}-\frac{d}{d t} f_{\dot{x}}=0$, maka suku kedua pada persamaan ( 2.29) haruslah memenuhi

$$
\left.h f_{\dot{x}}\right|_{0} ^{T}=0
$$

Jika titik awal $A\left(0, x_{0}\right)$ dan titik terminal $B\left(T, x_{T}\right)$ merupakan dua titik tetap, maka $h(0)=$ $0=h(T)$, atau $X(0)=x_{0}, x(T)=x_{T}$ dan persamaan ( 2.30) dipenuhi. Permasalahan seperti ini dikenal dengan sebutan masalah dua titik ujung tetap.

Apabila titik ujung $x(0)$ dan $x(T)$ tidak diberikan, maka fungsi $h(t)$ tidak lagi memenuhi $h(0)=0=h(T)$. Sehingga untuk dapat terpenuhinya persyaratan (2.30) haruslah dipenuhi

$$
f_{\dot{x}}=0 \text { pada } t=0 \text { dan } f_{\dot{x}}=0 \text { pada } t=T \text {. }
$$

Persyaratan ini dikenal dengan sebutan syarat batas natural. Persamaan ( 2.31) akan menentukan konstanta integrasi.

Contoh 2.8 Perhatikan masalah brachistochrone yang meminimumkan fungsional objektif

$$
J(x)=\int_{0}^{T} / \operatorname{sqrt}\left(1+\dot{x}^{2}\right) d t
$$

Solusi : $\quad$ Persamaan Euler memberikan $\ddot{x}=0$, yang memberikan solusi $x(t)=a t+b$. Apabila $x(0)=4$ dan $T=10$, tetapi $x(10)$ belum ditentukan, maka kita gunakan syarat $\left.f_{\dot{x}}\right|_{t=10}=0$, yaitu

$$
\left.f_{\dot{x}}\right|_{t=10}=\frac{\dot{x}(10)}{\left(1+\dot{x}^{2}(10)\right)^{1 / 2}}=0,
$$

memberikan $\dot{x}(10)=a=0$. Sedangkan $x(0)=4$ memberikan $b=4$, sehingga diperoleh solusi khusus $x(t)=4$. 


\subsubsection{Titik Ujung Bebas}

Perhatikan masalah menentukan ekstremum untuk fungsional objektif

$$
J(x)=\int_{t_{0}}^{T} f(x, \dot{x}, t) d t
$$

dengan $t_{0}, \quad T, \quad x\left(t_{0}\right)$ dan $x(T)$ semuanya belum diketahui. Untuk memudahkan pembahasan, misalkan $t_{0}=0$ dan $x(0)=x_{0}$ adalah tetap, sedangkan $T$ dan $x(T)$ adalah bebas. Variasi pertama adalah

$$
\begin{aligned}
\delta J & =\int_{0}^{T}\left(f_{x} h+f_{\dot{x}} \dot{h}\right) d t+\left.f(.)\right|_{T} \delta T \\
& =\int_{0}^{T}\left(f_{x}-\frac{d}{d t} f_{\dot{x}}\right) h d t+\left.h f_{\dot{x}}\right|_{T}+\left.f(.)\right|_{T} \delta T
\end{aligned}
$$

Karena variasi pada titik ujung tidak mempengaruhi variasi dalam selang terbuka $(0, T)$, maka syarat perlu untuk $\delta J=0$ adalah dipenuhinya persamaan Euler, yaitu

$$
f_{x}-\frac{d}{d t} f_{\dot{x}}=0
$$

Akibatnya, persamaan (2.33) menjadi $\delta J=\left.f_{\dot{x}} h\right|_{T}+\left.f()\right|_{T.} \delta T=0 . \quad$ Dengan menggunakan informasi $h(T)=\delta x_{T}-\dot{x}(T) \delta T$, menghasilkan Syarat Batas atau Syarat Transversalitas :

$$
\left(\left.f(.)\right|_{T}-\left.\dot{x} f_{\dot{x}}\right|_{T}\right) \delta T+\left.f_{\dot{x}}\right|_{T} \delta x_{T}=0 .
$$

Syarat batas ini akan menentukan nilai $T$ dan $x_{T}$. Terdapat dua kasus yang perlu diperhatikan. Kasus pertama apabila variasi $\delta x_{T}$ dan $\delta T$ saling bebas. Akibatnya, koefisien dari $\delta x_{T}$ dan $\delta T$ dalam persamaan ( 2.35) masing-masing sama dengan nol, yaitu

$$
\left.f(.)\right|_{T}-\left.\dot{x} f_{\dot{x}}\right|_{T}=0, \quad \text { dan }\left.\quad f_{\dot{x}}\right|_{T}=0
$$

yang secara bersama menghasilkan

$$
\left.f(.)\right|_{T}=0=\left.f_{\dot{x}}\right|_{T}
$$

Kasus kedua terjadi apabila titik ujung $B\left(T, x_{T}\right)$ bergerak sepanjang kurva $x(t)=g(t)$. Untuk kasus ini, maka $\delta x_{T}=\dot{g}(T) \delta T$. Dengan substitusi ini ke dalam persamaan ( 2.35) menghasilkan

$$
\left(f(.)+[\dot{g}(T)-\dot{x}(T)] f_{\dot{x}}\right)_{t=T} \delta T=0 .
$$


Analisis yang sama berlaku pula untuk kasus titik awal bebas, yaitu apabila $t_{0}$ dan $x\left(t_{0}\right)$ bebas. Secara umum, Syarat Transversalitas atau Syarat Batas ( 2.35) menjadi

$$
\left.\left[f(.)-\dot{x} f_{\dot{x}}\right] \delta t\right|_{t=t_{0}} ^{t=T}+\left.f_{\dot{x}} \delta x(t)\right|_{t=t_{0}} ^{t=T}=0
$$

Dengan cara yang sama seperti analisis untuk satu titik ujung tetap, maka untuk kasus variasi $\delta x_{T}$ dan $\delta T$ saling bebas, diperoleh

$$
\left.f(.)\right|_{t=t_{0}} ^{t=T}=0=\left.f_{\dot{x}}\right|_{t=t_{0}} ^{t=T}
$$

dan untuk kasus titik ujung bergerak sepanjang kurva $g$, akan diperoleh

$$
\left.\left[f(.)+(\dot{g}-\dot{x}) f_{\dot{x}}\right]\right|_{t=t_{0}} ^{t=T} \delta T=0
$$

Syarat Transversalitas di atas mencakup semua kasus yang ada, sebagai berikut:

1. Apabila kedua titik ujung terletak pada garis lurus $t=t_{0}$ dan $t=T$, maka $\delta t_{0}=0=\delta T$ sehingga suku pertama dalam persamaan ( 2.39) menjadi nol dan persamaan ( 2.39) menjadi

$$
\left.f_{\dot{x}} \delta x(t)\right|_{t=t_{0}} ^{t=T}=0
$$

2. Apabila titik ujung $\mathrm{A}$ dan $\mathrm{B}$ tetap, yaitu $x\left(t_{0}\right), \quad x(T)$ dan $t_{0}$ dan $T$ tetap, maka $\delta t_{0}=0=\delta T$ dan $\delta x(0)=0=\delta x(T)$. Jadi kita mempunyai masalah dua titik ujung tetap, dan konstanta integrasi ditentukan oleh syarat batas pada titik A dan B.

3. Apabila $x_{0}$ dan $x_{T}$ tetap, tetapi $t_{0}$ dan $T$ bebas, maka $\delta x(0)=0=\delta x(T)$, tetapi $\delta t_{0} \neq 0$ dan $\delta T \neq 0$. Persamaan ( 2.39) memberikan

$$
\left.\left(f(.)-\dot{x} f_{\dot{x}}\right)\right|_{t=t_{0}} ^{t=T}=0
$$

4. Titik ujung bebas, yaitu $x_{0}, x_{T}, t_{0}$ dan $T$ semuanya bebas, maka Syarat Transversalitas ( 2.39) harus dipenuhi. Dalam hal ini,

$$
\left.\left(f(.)-\dot{x} f_{\dot{x}}\right)\right|_{t=t_{0}} ^{t=T}=0
$$

dan

$$
\left.f_{\dot{x}}\right|_{t=t_{0}} ^{t=T}=0 .
$$


5. Titik ujung bebas, yaitu $x\left(t_{0}\right), x(T), t_{0}$ dan $T$ semuanya bebas, tetapi $x\left(t_{0}\right)$ dan $x(T)$ harus bergerak sepanjang kurva $x\left(t_{0}\right)=g_{1}\left(t_{0}\right)$ dan $x(T)=g_{2}(T)$. Maka konstanta integrasi akan ditentukan oleh

$$
\left.\left[f+\left(\dot{g}_{1}-\dot{x}\right) f_{\dot{x}}\right]\right|_{t=t_{0}}=0
$$

dan

$$
\left.f+\left(\dot{g}_{2}-\dot{x}\right) f_{\dot{x}}\right]\left.\right|_{t=T}=0
$$

6. Kombinasi dari semua kasus-kasus di atas.

7. Kadangkala dalam masalah ekonomi, syarat yang diberikan pada titik ujung tidak selalu dalam bentuk suatu nilai, tapi dibatasi oleh suatu nilai. Misalnya, jumlah produksi $x$ pada waktu terminal haruslah lebih besar dari suatu nilai.

Perhatikan masalah memaksimumkan fungsional objektif

$$
\begin{gathered}
J(x)=\int_{t_{0}}^{T} f(x, \dot{x}, t) d t, \quad x\left(t_{0}\right)=x_{0}, \\
x(T) \geq x_{T}, \quad\left(x_{T} \quad \text { diberikan, } T \quad \text { tetap. }\right) .
\end{gathered}
$$

Maka syarat batas yang harus dipenuhi oleh masalah seperti ini adalah

$$
\left.\frac{\partial f}{\partial \dot{x}}\right|_{t=T} \leq 0, \quad\left(=0, \quad \text { jika } x(T)>x_{T}\right) .
$$

Definisikan

$$
\begin{aligned}
p(t) & \equiv-\partial f / \partial \dot{x} \\
H & \equiv f(x, \dot{x}, t)-\dot{x} f_{\dot{x}} \equiv f+p \dot{x} .
\end{aligned}
$$

Syarat Transversalitas ( 2.39) dapat dituliskan dalam bentuk

$$
\left.(H \delta t+p \delta x)\right|_{t=t_{0}} ^{t=T}=0 .
$$

Untuk kasus waktu awal $t_{0}$ dan waktu terminal $T$ bebas, maka $H\left(t_{0}\right)=0=H(T)$. Sedangkan untuk kasus $x\left(t_{0}\right)$ dan $x(T)$ belum ditentukan maka $p\left(t_{0}\right)=0=p(T)$. 
Syarat Batas dan Penentuan Konstanta Integrasi

\begin{tabular}{|c|c|c|}
\hline Kasus & Substitusi & Syarat Batas \\
\hline$T$ dan $x(T)$ & $\delta x_{T}=0$ & $x^{\star}(0)=x_{0}$ \\
dua2nya ditentukan & $\delta T=0$ & $x^{\star}(T)=x_{T}$ \\
\hline$x(T)$ bebas & $\delta x(T) \neq 0$ & $x^{\star}(0)=x_{0}$ \\
$T$ ditentukan & $\delta T=0$ & $\left.f_{\dot{x}_{i}}\right|_{t=T}=0$ \\
\hline$x(T)=x_{T}$ tetap & $\delta x_{T}=0$ & $x^{\star}(0)=x_{0}$ \\
$T$ bebas & $\delta T \neq 0$ & $x^{\star}(T)=x_{T}$ \\
\hline$x(T)$ dan $T$ & $\delta x(T) \neq 0$ & $\left.H \equiv\left(f-\dot{x} f_{\dot{x}}\right)\right|_{t=T}=0$ \\
\hline dua2nya belum ditentukan & $\delta T \neq 0$ & $x^{\star}(0)=x_{0}$ \\
dan saling bebas & & $\left.f_{\dot{x}}\right|_{t=T}=0$ \\
\hline$x(T)$ dan $T$ bebas & $\dot{x}(T)=\dot{g}(T) \delta T$ & $x^{\star}(0)=x_{0}, \quad x^{\star}(T)=g(T)$ \\
tetapi $x(T)=g(T)$ & $\delta x_{i}(T)=\dot{g}_{i}(T) \delta T$ & $\left.\left(f+(\dot{g}(T)-\dot{x}(T)) f_{\dot{x}}\right)\right|_{t=T}=0$ \\
\hline$T$ tetap $x_{T}$ diberikan & & $\left.f_{\dot{x}}\right|_{t=T} \leq 0, \quad\left(=0, \quad x(T)>x_{T}\right)$ \\
$x(T) \geq x_{T}$ & & \\
\hline
\end{tabular}

Contoh 2.9 Perhatikan masalah meminimumkan fungsional objektif $J(x)$ dengan

$$
J(x)=\int_{0}^{2}\left(\dot{x}^{2}+x \dot{x}+2 \dot{x}+4 x\right) d t
$$

dengan $x(0)$ dan $x(2)$ belum ditentukan.

Solusi : Persamaan Euler memberikan $\ddot{x}=2$, dengan solusinya adalah

$$
x(t)=t^{2}+k_{1} t+k_{2} .
$$

Konstanta $k_{1}$ dan $k_{2}$ akan ditentukan dari syarat

$$
f_{\dot{x}}=2 \dot{x}+x+2=0, \quad \text { untuk } \quad t=0, \quad \text { dan } t=2 .
$$

Syarat di atas memberikan $k_{1}=-6, \quad k_{2}=10$. Sehingga diperoleh solusi

$$
x(t)=t^{2}-6 t+10 .
$$


Contoh 2.10 Tentukan ekstremum untuk fungsional objektif

$$
J(x)=\int_{0}^{T}\left(x+\dot{x}^{2}\right) d t
$$

dengan setiap kasus kendala berikut:

1. $x(0)=1, T=2, x(2)=10 \quad$ (dua titik ujung tetap $)$.

2. $x(0)=1, T=2, x(2)$ bebas (titik ujung bebas).

3. $x(0)=1, x(T)=4, T$ bebas tetapi $T>2$ ( waktu terminal bebas ).

Solusi : Persamaan Euler memberikan $1-2 \ddot{x}=0$, yang memberikan solusi

$$
x(t)=\frac{1}{4} t^{2}+k_{1} t+k_{2},
$$

dengan konstanta $k_{1}$ dan $k_{2}$ akan ditentukan untuk setiap kasus sebagai berikut:

1. $x(0)=1 \Rightarrow k_{2}=1, \quad x(2)=10 \Rightarrow k_{1}=4$, sehingga solusi adalah

$$
x(t)=\frac{1}{4} t^{2}+4 t+1 .
$$

2. $x(0)=1 \Rightarrow k_{2}=1$. Untuk menentukan $k_{1}$ gunakan $f_{\dot{x}}=2 \dot{x}=0$ pada $t=T$, yaitu $\dot{x}(T)=0$, memberikan $k_{1}=-1$. Jadi, diperoleh solusi

$$
x(t)=\frac{1}{4} t^{2}-t+1
$$

3. $x(0)=1 \Rightarrow k_{2}=1$. Untuk menentukan $k_{1}$ gunakan persyaratan $\left.\left(f-\dot{x} f_{\dot{x}}\right)\right|_{t=T}=0$, yang menghasilkan $-\dot{x}^{2}(T)+x(T)=0$. Ini akan memberikan $k_{1}= \pm 1$. Untuk $k_{1}=$ $1 \Rightarrow T=2$. sedangkan untuk $k_{1}=-1 \Rightarrow T=6$. Karena $T>2$, maka haruslah $k_{1}=-1$. Sehingga diperoleh solusi optimum adalah

$$
x(t)=\frac{1}{4} t^{2}-t+1, \quad T=6 .
$$




\subsection{Syarat Cukup / Sufficiency Conditions}

\subsubsection{Variasi Fungsional}

Perhatikan fungsional objektif

$$
J(x)=\int_{0}^{T} f(x, \dot{x}, t) d t .
$$

Variasi total dari fungsional objektif adalah

$$
\begin{aligned}
\triangle J(h) & \equiv J(x+h)-J(x) \\
& =\int_{0}^{T}\left(f_{x} h+f_{\dot{x}} \dot{h}\right) d t+\frac{1}{2} \int_{0}^{T}\left(f_{x x} h^{2}+2 f_{x \dot{x}} h \dot{h}+f_{\dot{x} \dot{x}} \dot{h}^{2}\right) d t+O(\|h\|)^{2} \\
& \equiv \delta J(h)+\delta^{2} J(h)+O(\|h\|)^{2} \\
& =\text { variasi pertama }+ \text { variasi kedua }+ \text { orde lebih tinggi }
\end{aligned}
$$

dengan $O(\|h\|)^{2} \rightarrow 0$ untuk $h \rightarrow 0$.

Pada kurva ekstremum, $\delta J(h)=0$ dan $\triangle J(h)$ harus memiliki tanda yang sama dengan tanda $\delta^{2} J(h)$. Untuk memudahkan pembahasan, tuliskan variasi kedua sebagai berikut :

$$
\begin{aligned}
\delta^{2} J(h) & =\frac{1}{2} \int_{0}^{T}\left(f_{x x} h^{2}+2 f_{x \dot{x}} h \dot{h}+f_{\dot{x} \dot{x}} \dot{h}^{2}\right) d t \\
& \equiv \int_{0}^{T}\left(P \dot{h}^{2}+Q h^{2}\right) d t
\end{aligned}
$$

dengan $P \equiv P(t) \equiv \frac{1}{2} f_{\dot{x} \dot{x}} ; Q \equiv Q(t)=\frac{1}{2}\left(f_{x x}-\frac{d}{d t} f_{x \dot{x}}\right)$ dan dengan melakukan integrasi bagian maka diperoleh $\int_{0}^{T} 2 f_{x \dot{x}} h \dot{h} d t=-\int_{0}^{T}\left(\frac{d}{d t} f_{x \dot{x}}\right) h^{2} d t$. Untuk masalah meminimumkan, $\delta^{2} J(h) \geq 0$, dan untuk masalah memaksimumkan, $\delta^{2} J(h) \leq 0$. Untuk fokusnya, kita lihat masalah meminimumkan, dan untuk masalah memaksimumkan, tinggal mengganti tanda yang berlawanan. Akan dilihat kondisi-kondisi yang membuat $\delta^{2} J(h) \geq 0$.

Akan ditunjukkan bahwa $\delta^{2} J(h) \geq 0$, jika dan hanya jika $\left(P \dot{h}^{2}+Q h^{2}\right) \geq 0$ untuk semua $h(t)$ yang memenuhi $h(0)=0=h(T)$. Fungsi $h(t)$ yang memenuhi sifat ini bernilai kecil jika $\dot{h}(t), \forall t \in(0, T)$ juga bernilai kecil, tapi sebaliknya tidak berlaku. Apabila fungsi $h(t)$ yang bersifat seperti di atas dapat ditemukan demikian rupa sehingga $h(t)$ kecil tetapi $\dot{h}(t)$ besar untuk $\operatorname{tin}(0, T)$, maka $P \dot{h}^{2}$ mendominasi $Q h^{2}$ dalam penentuan tanda dari $\delta^{2} J(h)$, seperti yang ditunjukkan oleh lema dan teorema berikut. 


\subsubsection{Syarat Legendre}

Lema 2.2 Misalkan $\delta^{2} J(h)=\int_{0}^{T}\left(P \dot{h}^{2}+Q h^{2}\right) d t$ didefinisikan untuk fungsi $h(t)$, yang memiliki sifat dapat diturunkan pada $\forall t \in(0, T)$ dan memenuhi $h(0)=0=h(T)$. Maka syarat perlu untuk $\delta^{2} J(h)=\int_{0}^{T}\left(P \dot{h}^{2}+Q h^{2}\right) d t \geq 0$ adalah $P(t) \geq 0, \quad \forall t \in(0, T)$. Ini disebut Syarat Legendre.

Teorema 2.2 (Legendre). Syarat perlu bagi fungsional objektif $J(x)=\int_{0}^{T} f(x, \dot{x}, t) d t$ dengan syarat pada titik ujung $x(0)=x_{0}, \quad x(T)=x_{T}$ untuk memiliki nilai minimum ( atau maksimum ) untuk semua kurva $x=x(t)$ adalah dipenuhinya syarat Legendre $P(t) \geq 0$ untuk semua $t \in(0, T)$.

Teorema Legendre ini, sayangnya masih merupakan syarat perlu. Upaya Legendre untuk membuktikannya sebagai syarat cukup untuk optimum mengalami kegagalan.

\subsubsection{Syarat Jacobi}

Upaya Legendre yang gagal, membawa kepada suatu persamaan diferensial linier ordo-2 dalam $v$,

$$
-\frac{d}{d t}(P \dot{v})+Q v=0
$$

Teorema 2.3 Perhatikan persamaan diferensial orde-2

$$
-\frac{d}{d t}(P \dot{v})+Q v=0
$$

Jika $P>0 \quad(<0) \quad$ dan solusi $v(t)$ untuk semua fungsi $v(t)$ yang dapat diturunkan memenuhi sifat $v(0)=0=v(T)$, maka $\delta^{2} J>0 \quad(<0)$ artinya nilai minimum ( atau nilai maksimum ) telah diperoleh. Ini disebut syarat perlu Jacobi.

\subsubsection{Syarat Weierstrass untuk Ekstremal Kuat}

Teorema 2.4 Definisikan fungsi ekstra $E$ dengan

$$
E(x, \dot{x}, p, t)=f(x, \dot{x}, t)-f(x, p, t)-(\dot{x}-p) f_{p}
$$


dengan $p(t, x)$ adalah fungsi kemiringan/ 'slope' dari ekstremum yang melalui titik $(t, x)$. Apabila syarat perlu Jacobi dipenuhi maka $E \leq 0$ untuk masalah memaksimumkan dan $E \geq 0$ untuk masalah meminimumkan.

\subsubsection{Syarat Legendre-Clebsch}

Teorema 2.5 Fungsi ekstra E dapat disederhanakan menjadi

$$
E \equiv \frac{(\dot{x}-p)^{2}}{2 !} f_{\dot{x} \dot{x}}(t, x, q)
$$

dengan $q=\theta \dot{x}+(1-\theta) p, \quad(0<\theta<1)$. Supaya $x(t)$ mencapai minimum (atau maksimum) adalah cukup dipenuhi syarat Legendre-Clebsch $E \geq 0 \quad(\leq 0)$ yang berarti $f_{\dot{x} \dot{x}} \geq 0 \quad(\leq 0)$, atau dalam bentuk yang lebih umum, matriks $\left[f_{\dot{x} \dot{x}}\right]$ merupakan semi-definit positif ( atau negatif ) dan syarat perlu Jacobi dipenuhi untuk semua $\dot{x}$.

\subsubsection{Syarat Cukup : Kasus khusus}

Teorema 2.6 (Mangasarian). Misalkan $f(x, \dot{x}, t)$ merupakan fungsi yang dapat diturunkan dua kali dan concave/cembung (convex/cekung) dalam $x$ dan $\dot{x}$. Maka syarat perlu dan syarat cukup untuk $x^{\star}$ sebagai maksimum ( atau minimum ) dari fungsional $J(x)=\int_{0}^{T} f(x, \dot{x}, t) d t$ adalah dipenuhinya persamaan Euler dan $x(0)=x_{0}$, dan $x(T)=x_{T}$. 


\section{Bab 3}

\section{Kontrol Optimum : Pendekatan}

\section{Kalkulus Variasi}

\subsection{Formulasi Masalah Kontrol Optimum}

Teori kontrol optimum menunjukkan perkembangan yang sangat pesat pada tahun 50-an, dengan adanya penemuan dua metoda penyelesaian masalah kontrol optimum, yaitu penemuan metoda program dinamis atau dinamical programming oleh Richard Bellman (1957) dan penemuan metode prinsip maksimum atau maximum principle oleh ahli matematika Rusia yang bernama Lev Pontryagin (1962).

Untuk alasan kepraktisan, pembahasan dalam catatan kuliah ini akan difokuskan pada metoda prinsip maksimum, yang dapat didekati dengan metoda kalkulus variasi, terutama yang terkait dengan syarat perlu yang tertuang dalam persamaan Euler. Lagi pula, seperti yang sudah disinggung dalam bagian terdahulu, masalah kalkulus variasi dengan kendala persamaan diferensial merupakan suatu masalah kontrol optimum, dengan cara mengganti peubah $\dot{x}$ dengan peubah kontrol $u(t)$.

Perhatikan suatu masalah ekonomi yang berkembang menurut waktu. Pada waktu $t$, sistem berada dalam keadaan atau kondisi (state), yang dapat diungkapkan dengan peubah keadaan (state variables) $x_{1}(t), x_{2}(t), \ldots, x_{n}(t)$, atau dalam bentuk vektor $x(t) \in R^{n}$. Dengan 
nilai waktu $t$ yang berbeda, vektor $x(t)$ menempati posisi yang berbeda di ruang $R^{n}$. Dalam hal ini, kita katakan bahwa sistem bergerak sepanjang suatu kurva di $R^{n}$.

Misalkan proses yang terjadi pada ekonomi (yang membuat keadaan $x(t)$ bervariasi/bergerak) dapat dikendalikan atau dikontrol. Artinya, ada fungsi kontrol atau peubah-peubah kontrol atau peubah-peubah keputusan $u_{1}(t), u_{2}(t), \ldots, u_{k}(t)$ atau dalam bentuk vektor $u(t) \in$ $R^{k}, k \leq n$, yang mempengaruhi proses ekonomi. [Contoh peubah keputusan untuk hal ini dapat saja berupa pajak, tingkat suku bunga, alokasi investasi, dan lain sebagainya]. Tentunya kita harus mengetahui aturan/hukum/kaidah yang membentuk perilaku ekonomi sepanjang waktu, yang kita sebut dengan dinamika dari sistem.

Sistem yang akan kita lihat adalah sistem yang dibentuk oleh sistem persamaan diferensial :

$$
\dot{x}(t)=f(x(t), u(t), t)
$$

dengan fungsi-fungsi $f=\left(f_{1}, f_{2}, \ldots, f_{n}\right), f_{i}$ dan $\partial f_{i} / \partial x_{i}$ adalah fungsi-fungsi yang kontinu.

Misal $x(t)$ adalah state dari sistem yang diketahui pada waktu awal $t_{0}$ sehingga $x\left(t_{0}\right)=$ $x_{0}, x_{0} \in R^{n}$. Jika dipilih kontrol $u(t)=\left(u_{1}(t), u_{2}(t), \ldots, u_{k}(t)\right) \in R^{k}$ yang terdefinisi untuk waktu $t \geq t_{0}$, maka akan dapat diperoleh sistem $x(t)$. Jadi, state atau keadaan $x(t)$ merupakan respons atau tanggapan terhadap tindakan kontrol $u(t)$, sehingga kadang-kadang dituliskan juga sebagai $x_{u}(t)$. Untuk setiap fungsi kontrol $u(t)$ dan tanggapan keadaan $x_{u}(t)$ atau disingkat $x(t)$, dikaitkan suatu bilangan $J$ yang didefinisikan oleh

$$
J[u(t)]=S[x(T), T]+\int_{t_{0}}^{T} f_{0}(x(t), u(t), t) d t
$$

dengan fungsi $f_{0}$ adalah suatu fungsi yang diberikan dan $S[x(T), T]$ merupakan fungsi 'scrap'. Waktu akhir atau waktu terminal atau waktu tujuan $T$ tidak selalu harus tetap, dan keadaan akhir atau keadaan pada waktu tujuan $x(T)$ dapat saja memiliki batasan tertentu.

Definisi 3.1 Misalkan $\mathcal{U}$ menyatakan kelas dari semua fungsi yang kontinu bagian. Masalah kontrol optimum (kita singkat saja dengan MKO) adalah masalah menentukan fungsi kontrol $u^{\star}(t)$ diantara fungsi admissible $u(t) \in \mathcal{U}$ yang membawa sistem dari state awal $x_{0}$ kepada state akhir/terminal $x_{T}$ yang memenuhi kondisi akhir/terminal, melalui sistem persamaan 
diferensial

$$
\dot{x}(t)=f(x(t), u(t), t)
$$

sehingga fungsional J mencapai nilai maksimum. Dengan kata lain, masalah kontrol optimum adalah masalah memaksimumkan fungsional objektif

$$
\max _{u(t) \in \mathcal{U}} J[u(t)]=S[x(T), T]+\int_{t_{0}}^{T} f_{0}(x(t), u(t), t) d t
$$

terhadap kendala $\dot{x}(t)=f(x(t), u(t), t), x\left(t_{0}\right)=x_{0}, x(t) \in R^{n}$.

\subsection{Syarat Perlu : Prinsip Maksimum Pontryagin}

Teorema 3.1 Misalkan $u^{\star}(t)$ sebagai kontrol admissible yang membawa state awal $\left(x\left(t_{0}\right), t_{0}\right)$ kepada target state tujuan $(x(T), T)$, dengan $x(T)$ dan $T$ secara umum tidak ditentukan. Misalkan $x^{\star}(t)$ merupakan trajektori state dari sistem yang berkaitan dengan kontrol $u^{\star}(t)$. Supaya kontrol $u^{\star}(t)$ merupakan kontrol optimum adalah perlu terdapatnya fungsi vektor $p^{\star}(t) \neq 0$, dan konstanta $p_{0}$ demikian rupa sehingga

1. $p^{\star}(t)$ dan $x^{\star}(t)$ merupakan solusi dari sistem kanonik

$$
\begin{aligned}
& \dot{x}^{\star}(t)=\frac{\partial H}{\partial p}\left(x^{\star}(t), u^{\star}(t), p^{\star}(t), t\right) \\
& \dot{p}^{\star}(t)=-\frac{\partial H}{\partial x}\left(x^{\star}(t), u^{\star}(t), p^{\star}(t), t\right)
\end{aligned}
$$

dengan fungsi Hamilton $H$ diberikan oleh

$$
H(x, u, p, t)=f_{0}(x(t), u(t), t)+p . f(x(t), u(t), t)
$$

dengan $p_{0} \equiv 1$.

2. $H\left(x^{\star}(t), u^{\star}(t), p^{\star}(t), t\right) \geq H(x(t), u(t), p(t), t)$

3. Semua syarat batas dipenuhi.

Bukti : Untuk memudahkan pembahasan, ambil $t_{0}=0$ dan $x(0)=x_{0}$. Tuliskan fungsi 'scrap' $S[x(T), T]$ dalam bentuk

$$
S[x(T), T] \equiv S\left[x_{0}, 0\right]+\int_{0}^{T} \frac{d}{d t} S[x(t), t] d t
$$


sehingga fungsional objektif $J$ dalam persamaan ( 3.2 ) dapat ditulis dalam bentuk yang berikut :

$$
\begin{aligned}
J[u(t)] & =S\left[x_{0}, 0\right]+\int_{t_{0}}^{T}\left[f_{0}(x(t), u(t), t)+\frac{d}{d t} S(x(t), t)\right] d t \\
& =S\left[x_{0}, 0\right]+\int_{t_{0}}^{T}\left[f_{0}(.)+\frac{\partial S}{\partial x} \dot{x}+\frac{\partial S}{\partial t}\right] d t
\end{aligned}
$$

Suku $S\left[x_{0}, 0\right]$ dapat diabaikan untuk mempermudah pembahasan, karena $x(0)=x_{0}$ sudah tetap, sehingga tidak mempengaruhi proses optimisasi.

Tuliskan fungsional objektif yang diperluas $J_{a}(u)$ sebagai berikut

$$
J_{a}(u) \equiv=\int_{t_{0}}^{T} L(x, \dot{x}, p, u, t) d t
$$

dengan fungsi $L$ didefinisikan oleh

$$
\begin{aligned}
L(x, \dot{x}, p, u, t) & \equiv f_{0}(.)+p[f(.)-\dot{x}]+\frac{\partial S}{\partial x} \dot{x}+\frac{\partial S}{\partial t} \\
& \equiv H(x, u, p, t)-p \dot{x}+\frac{\partial S}{\partial x} \dot{x}+\frac{\partial S}{\partial t}
\end{aligned}
$$

dengan $H(x, u, p, t) \equiv f_{0}(x, u, t)+p f(x, u, t)$ merupakan fungsi Hamilton.

Dengan menggunakan syarat perlu untuk adanya ekstremum pada fungsional objektif yang diperluas, maka

$$
\begin{aligned}
\delta J_{a}(u) & =\int_{0}^{T}\left[\left(L_{x}-\frac{d}{d t} L_{\dot{x}}\right) \delta x+L_{u} \delta u+L_{p} \delta p\right] d t \\
& +\left[L_{\dot{x}} \delta x+\left(L-L_{\dot{x}} \dot{x}\right) \delta t\right]_{t=T}=0 .
\end{aligned}
$$

Karena persamaan Euler harus dipenuhi, maka haruslah

$$
\begin{aligned}
L_{x}-\frac{d}{d t} L_{\dot{x}} & =H_{x}+\frac{\partial}{\partial x}\left(S_{x} \dot{x}+S_{t}\right)-\frac{d}{d t}\left(S_{x}-p\right) \\
& =H_{x}+S_{x x} \dot{x}+S_{x t}-S_{x x} \dot{x}-S_{x t}+\dot{p} \\
& =H_{x}+\dot{p}=0 .
\end{aligned}
$$

Ini memberikan

$$
\dot{p}=-H_{x}
$$

Karena $\delta u$ dan $\delta p$ adalah sebarang dan saling bebas, maka haruslah $L_{u}=0$ dan $L_{p}=0$. Dari pendefinisian fungsi $L$, maka

$$
L_{u}=H_{u}, \quad \text { dan } L_{p}=f(.)-\dot{x}=H_{p}-\dot{x}
$$


sehingga diperoleh

$$
\begin{aligned}
H_{u} & =0 \\
\dot{x} & =f(x, u, t)=H_{p}
\end{aligned}
$$

Syarat transversalitas atau syarat batas diberikan oleh suku-suku sisanya, yaitu

$$
\left[L_{\dot{x}} \delta x+\left(L-L_{\dot{x}} \dot{x}\right) \delta t\right]_{t=T}=0
$$

Tetapi

$$
\begin{aligned}
L_{\dot{x}} & =S_{x}-p \\
L-L_{\dot{x}} \dot{x} & \equiv H-p \dot{x}+S_{x} \dot{x}+S_{t}-\dot{x} S_{x}+\dot{x} p \\
& =H+S_{t}
\end{aligned}
$$

sehingga diperoleh syarat batas

$$
\left.\left(S_{x}-p\right) \delta x\right|_{t=T}+\left.\left[H(t)+S_{t}\right] \delta t\right|_{t=T}=0 .
$$

Apabila $x\left(t_{0}\right)$ dan $t_{0}$ dua-duanya belum ditentukan pula, maka syarat batas menjadi

$$
\left.\left(S_{x}-p\right) \delta x\right|_{t=t_{0}} ^{t=T}+\left.\left[H(t)+S_{t}\right] \delta t\right|_{t=t_{0}} ^{t=T}=0
$$

yang menghasilkan teorema Pontryagin.

\section{Catatan :}

1. $H\left(x^{\star}(t), u^{\star}(t), p^{\star}(t), t\right) \geq H(x(t), u(t), p(t), t)$ disebut dengan Prinsip Maksimum Pontryagin. Kondisi ini dipenuhi oleh $H_{u}=0$ dan $H_{u u}<0$, untuk masalah yang kita bicarakan. Jika $u \in \mathcal{U}$ dan $\mathcal{U}$ himpunan tertutup, maka $H_{u}=0$ tidak memiliki arti, kecuali maksimum dari $H$ diberikan oleh bagian dalam (interior ) himpunan $\mathcal{U}$.

2. Jika $H$ merupakan fungsi monoton naik dalam peubah $u$, dan $\mathcal{U}$ tertutup, maka kontrol optimum adalah $u_{i_{\max }}$ untuk masalah memaksimumkan dan $u_{i_{\min }}$ untuk masalah meminimumkan. Jika $H$ merupakan fungsi monoton turun, maka kontrol optimum adalah $u_{i_{\min }}$ untuk masalah memaksimumkan dan $u_{i_{\max }}$ untuk masalah meminimumkan. Hal 
ini juga berlaku apabila $H$ adalah fungsi linier dalam $u$. Sehingga peubah kontrol optimum $u_{i}$ adalah kontinu bagian dan loncat dari satu vertex ke vertex lainnya. Ini adalah kasus khusus dari kontrol 'bang-bang.'

3. $H\left(x^{\star}(t), u^{\star}(t), p^{\star}(t), t\right) \geq H(x(t), u(t), p(t), t)$ juga mencakup syarat cukup.

4. Vektor $p$ disebut juga vektor adjoint, memiliki peranan sebagai pengali Lagrange. Dalam masalah optimisasi dinamis, peubah atau vektor adjoint merupakan 'shadow price' (atau disebut juga dengan nilai marginal) dari vektor atau peubah $x$, yang menunjukkan jumlah kenaikan/penurunan untuk setiap kenaikan/penurunan dalam nilai $x$ pada waktu $t$ yang berkontribusi terhadap fungsional objektif optimum $J$. Sedangkan $\dot{p}$ mengindikasikan tingkat kenaikan (appresiasi untuk $\dot{p}>0$,) atau penurunan ( depresiasi untuk $\dot{p}<0$ )dalam nilai dari tiap unit modal.

5. $d H / d t=\partial H / \partial t$.

6. $\dot{p}=-H_{x}, \quad H_{u}=0, \quad \dot{x}=H_{p}$ memberikan syarat perlu untuk masalah yang dibicarakan.

7. Syarat batas diberikan oleh persamaan (3.22). Apabila fungsi scrap $S=0$, maka persamaan ( 3.22) menjadi

$$
\left.p(t) \delta x(t)\right|_{t=t_{0}} ^{t=T}+\left.H(t) \delta t\right|_{t=t_{0}} ^{t=T}=0
$$

Khususnya, apabila waktu awal $t_{0}$ dan $x\left(t_{0}\right)$ telah ditentukan, sedangkan waktu akhir $T$ dan keadaan pada waktu akhir $x(T)$ belum ditentukan, maka syarat batas menjadi

$$
-p(T) \delta x(T)+H(T) \delta T=0 .
$$

Contoh 3.1 Minimumkan fungsional objektif

$$
J(u(t))=\int_{0}^{1}\left(x+u^{2}\right) d t
$$

dengan syarat batas

$$
\dot{x}(t)=-u(t) ; \quad x(0)=0, \quad x(1) \quad \text { bebas } .
$$


Solusi : Dalam masalah di atas, $f_{0}(x, u, t)=x+u^{2}$, fungsi $f(x, u, t)=-u(t)$. Maka fungsi Hamilton adalah

$$
H(x, u, p, t)=f_{0}(x, u, t)+p f(x, u, t)=x+u^{2}+p(-u(t))
$$

sehingga diperoleh

$$
H_{u}=2 u(t)-p(t) \Rightarrow u^{\star}(t)=p(t) / 2 ; \quad H_{u u}=2>0 .
$$

$\dot{p}(t)=-H_{x}=-1$, memberikan $p(t)=-t+k_{1}$. Karena fungsi scrap $S=0$, dan $x(1)$ belum ditentukan ( dan $T=1$ ), maka syarat batas $p(1) \delta x(1)=0$, yang memberikan $p(1)=$ $-1+k_{1}=0$, yaitu $k_{1}=1$, dan $p(t)=-t+1$. Sistem dinamis menjadi

$$
\begin{aligned}
\dot{x}(t) & =-u(t)=-p(t) / 2 \\
& =-\frac{1}{2}(-t+1)=\frac{t}{2}-\frac{1}{2},
\end{aligned}
$$

yang memberikan solusi

$$
x(t)=t^{2}-\frac{1}{2}+k_{2}
$$

dengan $k_{2}=0$, karena $x(0)=0$. Jadi solusi optimum adalah

$$
\begin{aligned}
x^{\star}(t) & =t^{2}-\frac{1}{2} \\
p^{\star}(t) & =-t+1 \\
u^{\star}(t) & =\frac{t}{2}-\frac{1}{2}
\end{aligned}
$$

Contoh 3.2 Minimumkan fungsional objektif

$$
J(u(t))=\frac{1}{2} x(1)^{2}+\frac{1}{2} \int_{0}^{1} u^{2} d t
$$

dengan kendala $\dot{x}=-u(t), \quad x(0)=1$.

Solusi : Fungsi Hamilton adalah $H=\frac{1}{2} u^{2}-p u$, sehingga $H_{u}=u-p=0$. Ini memberikan $u(t)=p(t) ; H_{u u}=1>0 . \dot{p}=-H_{x}=0$. Ini memberikan $p(t)=k$, konstanta. Sedangkan $\dot{x}=-u=-p$ memberikan

$$
x(t)=-p t+k_{1}==-p t+1, \quad \text { karena } \quad x(0)=1 .
$$


Syarat batas $p(1)=S_{x}=x(1)$ memberikan $p(1)=x(1)=-p+1$, yaitu $p^{\star}(t)=\frac{1}{2}$. Sehingga diperoleh solusi optimum

$$
x^{\star}(t)=-\frac{1}{2} t+1, \quad p^{\star}(t)=u^{\star}(t)=\frac{1}{2} .
$$

Perhatikan masalah kontrol optimum satu dimensi yang memaksimumkan fungsional objektif $J$

$$
\max _{u(t) \in \mathcal{U}} J[u(t)]=\int_{t_{0}}^{T} f_{0}(x(t), u(t), t) d t
$$

terhadap kendala

$$
\dot{x}(t)=f(x(t), u(t), t), \quad x\left(t_{0}\right)=x_{0}, T \text { dan } x_{T} \text { tetap }
$$

dan salah satu dari syarat terminal berikut :

1. $x(T)=x_{T}$,

2. $x(T) \geq x_{T}$,

3. $x(T)$ bebas

dan kontrol $u(t) \in \mathcal{U}$.

Teorema 3.2 Syarat perlu untuk adanya kontrol optimum adalah $\exists\left(p_{0}, p(t)\right) \neq(0,0)$ dan

$$
\begin{aligned}
H\left(x^{\star}(t), u^{\star}(t), p^{\star}(t), t\right) & \geq H(x(t), u(t), p(t), t) \\
\dot{x}^{\star}(t) & =\frac{\partial H}{\partial p}\left(x^{\star}(t), u^{\star}(t), p^{\star}(t), t\right) \\
\dot{p}^{\star}(t) & =-\frac{\partial H}{\partial x}\left(x^{\star}(t), u^{\star}(t), p^{\star}(t), t\right) \\
p_{0} & =1 \text { atau } p_{0}=0,
\end{aligned}
$$

dan syarat batas yang sesuai adalah:

1. $p(T)$ tanpa syarat,

2. $p(T) \geq 0 \quad\left(=0 \quad\right.$ jika $\left.x^{\star}(T)>x(T)\right)$,

3. $p(T)=0$. 


\subsection{Syarat Transversalitas Atau Syarat Batas}

Perhatikan masalah kontrol optimum yang memaksimumkan fungsional objektif

$$
\max _{u(t) \in \mathcal{U}} J[u(t)]=S[x(T), T]+\int_{t_{0}}^{T} f_{0}(x(t), u(t), t) d t
$$

terhadap kendala

$$
\dot{x}(t)=f(x(t), u(t), t), \quad x\left(t_{0}\right)=x_{0}, \quad x(t) \in R^{n} .
$$

Maka syarat batas diberikan oleh

$$
\left.\left(S_{x}-p\right) \partial x\right|_{t=T}+\left.\left[H+S_{t}\right] \partial t\right|_{t=T}=0
$$

\subsubsection{Masalah Waktu Terminal $T$ Tetap}

Dengan waktu terminal $T$ tetap, maka $\delta T=0$, dan persamaan (3.32) menjadi

$$
\left.\left(S_{x}-p\right) \partial x\right|_{t=T}=0
$$

Terdapat 3 kasus untuk masalah waktu terminal tetap ini, yaitu :

Kasus 1 : State terminal (keadaan pada waktu akhir) tetap, $x(T)=x_{T}$.

Untuk kasus ini, jelas bahwa $\delta x(T)=0$, dan persamaan ( 3.32) tidak memberikan informasi apa-apa. Malahan informasi tersebut tidak diperlukan, karena konstanta integrasi akan diberikan oleh $x\left(t_{0}\right)=x_{0}$ dan oleh $x(T)=x_{T}$.

Kasus 2 : State Terminal Bebas.

Untuk kasus ini, jelas bahwa $\delta x(T) \neq 0$ sehingga diperoleh $p(T)=S_{x}$. Apabila tanpa $S[x(T), T]$, yaitu $S[x(T), T]=0$, maka syarat batas adalah $p(T)=0$.

Kasus 3 : State Terminal berada pada manifold $M[x(T), T]=0$.

Apabila state terminal berada pada manifold $M[x(T), T]=0$ dengan $M$ merupakan vektor, maka syarat batas menjadi

$$
\left.\left(R_{x}-p\right) \partial x\right|_{t=T}=0
$$


dengan

$$
R[x(T), T] \equiv S[x(T), T]+\mu M[x(T), T]
$$

dengan $\mu$ merupakan pengali Lagrange. Jadi syarat batas menjadi $p(T)=R_{x}$.

\subsubsection{Masalah Waktu Terminal $T$ Bebas}

Syarat batas menjadi

$$
\left.\left(R_{x}-p\right) \partial x\right|_{t=T}+\left.\left[H+S_{t}\right] \partial t\right|_{t=T}=0 .
$$

Terdapat 3 kasus untuk masalah ini, yaitu :

Kasus 4 : State Terminal $x(T)=x_{T}$ Tetap

Jelas bahwa $\delta x(T)=0$, sehingga diperoleh

$$
H(T)+\left.S_{t}\right|_{t=T}=0 .
$$

Apabila tanpa fungsi scrap, maka $H(T)=0$.

Kasus 5 : State Terminal $x(T)$ Bebas, yaitu $\delta x(T) \neq 0$.

Maka syarat batas menjadi

$$
p(T)=S_{x}[x(T), T], \quad \text { dan } H(T)+\left.S_{t}\right|_{t=T}=0
$$

Apabila fungsi scrap tidak ada, maka $p(T)=0=H(T)$.

Kasus 6 : $\quad$ State Terminal Bebas, tapi memenuhi $M[x(T), T]=0$.

Maka syarat batas menjadi

$$
p(T)=R_{x}, \quad H(T)+\left.R_{t}\right|_{t=T}=0, \quad M[x(T), T]=0 .
$$




\section{Ringkasan Syarat Batas/Transversality Conditions Kontrol Optimum}

$$
\left.\left(S_{x}-p\right) \delta x\right|_{t=T}+\left.\left[H(t)+S_{t}\right] \delta t\right|_{t=T}=0
$$

\begin{tabular}{|c|c|c|}
\hline Kasus & Substitusi & Syarat Batas \\
\hline \multicolumn{3}{|c|}{ Waktu Terminal $T$ tetap $(\delta T=0)$} \\
\hline$x(T)=x_{T}$ tetap & $\begin{array}{c}\delta x(T)=0 \\
\delta T=0\end{array}$ & $\begin{array}{c}x(0)=x_{0}, \quad x(T)=x_{T} \\
\text { (tidak ada batasan pada } p(T) \text { ) }\end{array}$ \\
\hline $\begin{array}{c}x(T) \text { bebas } \\
\text { yaitu } \delta x(T) \neq 0\end{array}$ & $\begin{array}{c}\delta x(T) \neq 0 \\
\delta T=0\end{array}$ & $\begin{array}{l}x(0)=x_{0} \\
p(T)=S_{x}\end{array}$ \\
\hline $\begin{array}{c}\text { State terminal } x(T) \\
\text { berada pada } M(x, t)=0\end{array}$ & $\begin{array}{c}\delta x(T) \neq 0 \\
\delta T=0\end{array}$ & $\begin{array}{c}x(0)=x_{0} \\
p(T)=S_{x}+M_{x}^{\prime} \mu \\
M(x(T), T)=0\end{array}$ \\
\hline \multicolumn{3}{|c|}{ Waktu Terminal $T$ bebas $(\delta T \neq 0)$} \\
\hline$x(T)=x_{T}$ tetap & $\begin{array}{c}\delta x(T)=0 \\
\delta T \neq 0\end{array}$ & $\begin{array}{c}x(0)=x_{0} \\
x(T)=x_{T} \\
H(T)+S_{t}=0 \text { pada } t=T\end{array}$ \\
\hline$x(T)$ bebas & $\begin{array}{c}\delta x(T) \neq 0 \\
\delta T \neq 0\end{array}$ & $\begin{array}{c}x(0)=x_{0} \\
p(T)=S_{x}[x(T), T] \\
H(T)+S_{t}=0 \text { pada } t=T\end{array}$ \\
\hline $\begin{array}{c}x(T) \text { tidak diberikan } \\
\text { berada pada manifold } \\
\qquad M(x(T), T)=0\end{array}$ & $\begin{array}{c}\delta x(T) \neq 0 \\
\delta T \neq 0\end{array}$ & $\begin{array}{c}x(0)=x_{0} \\
p(T)=R_{x} \equiv S_{x}+M_{x}^{\prime} \\
H(T)+R_{t}=0 \\
M=0\end{array}$ \\
\hline
\end{tabular}

\subsection{Syarat Cukup Untuk Kontrol Optimum}

Syarat $H\left(x^{\star}(t), u^{\star}(t), p^{\star}(t), t\right) \geq H(x(t), u(t), p(t), t)$ dalam Prinsip Maksimum Pontryagin sekaligus memberikan syarat cukup. Variasi total dari fungsional yang diperluas $J_{a}(u)$ adalah

$$
\triangle J_{a}(u) \equiv J_{a}(u)-J_{a}\left(u^{\star}\right)=\delta J_{a}(u)+\delta^{2} J_{a}(u)+O(u)
$$


Tanpa mempedulikan orde yang lebih tinggi $O(u)$ dan pada saat ekstremum variasi pertama $\delta J_{a}(u)=0$, maka terlihat bahwa tanda dari $\triangle J_{a}(u)$ ditentukan oleh tanda dari variasi kedua $\delta^{2} J_{a}(u)$, yang harus bertanda tak-positif untuk masalah maksimum dan tak-negatif untuk masalah minimum.

Dengan mengabaikan fungsi scrap, yaitu $S(x(T), t)=0$, maka variasi kedua $\delta^{2} J_{a}(u)$ diberikan oleh

$$
\delta^{2} J_{a}(u)=1 / 2 \int_{0}^{T}\left(\begin{array}{ll}
\delta x & \delta u
\end{array}\right)\left[\begin{array}{cc}
\frac{\partial^{2} H}{\partial^{2} x} & \frac{\partial^{2} H}{\partial x \partial u} \\
\frac{\partial^{2} H}{\partial u \partial x} & \frac{\partial^{2} H}{\partial^{2} u}
\end{array}\right]\left[\begin{array}{c}
\delta x \\
\delta u
\end{array}\right] d t
$$

dengan $H_{x x} \equiv\left[\delta^{2} H / \delta x_{i} \delta x_{j}\right]$, merupakan turunan dari $H_{x}$ terhadap $x$ yang dihitung pada $\left(x^{\star}, p^{\star}, u^{\star}, t\right)$. Hal yang sama berlaku untuk $H_{u x}\left(=H_{x u}\right)$ dan $H_{u u}$.

Teorema 3.3 Kontrol adalah maksimum lokal, dengan kata lain $u^{\star}(t)$ merupakan kontrol optimum dari fungsional J jika :

1. $\frac{\partial H}{\partial u}\left(x^{\star}(t), u^{\star}(t), p^{\star}(t), t\right)=0, \forall t \in[0, T] ;$

2. Variasi kedua $\delta^{2} J_{a}(u) \leq 0 \forall(\delta x, \delta u) \neq(0,0)$.

yang berakibat bahwa pada $u=u^{\star}, \frac{\partial^{2} H}{\partial^{2} u}$ adalah definit negatif dan matrik He (Hessian) berikut merupakan matrik definit negatif,

$$
H e=\left[\begin{array}{ll}
\frac{\partial^{2} H}{\partial^{2} x} & \frac{\partial^{2} H}{\partial x \partial u} \\
\frac{\partial^{2} H}{\partial u \partial x} & \frac{\partial^{2} H}{\partial^{2} u}
\end{array}\right]
$$

Teorema 3.4 Jika $f_{0}$ dan $f$, dan akibatnya $H=f_{0}+p$.f adalah fungsi concave, maka syarat perlu juga merupakan syarat cukup.

\section{Teorema 3.5 (Mangasarian Sufficiency Theorem).}

Misalkan $\left(x^{\star}, u^{\star}\right)$ merupakan pasangan admissible. Misalkan $\mathcal{U}$ concave dan $\partial f_{i} / \partial u_{j}$ ada dan kontinu. Jika $\exists p(t)=\left(p_{1}, p_{2}, \ldots, p_{n}\right)$ dan $p_{0}=1$ sehingga

1. $\dot{p}_{i}=-\frac{\partial H}{\partial x_{i}}, \forall i=1,2, \ldots, n$

2. $\sum \frac{\partial H}{\partial u_{j}}\left(u_{j}^{\star}(t)-u_{j}(t) \geq 0, \forall u \in \mathcal{U}\right.$ 
3. Hamiltonian $H$ adalah concave dalam $(x, u), \forall t$

maka $\left(x^{\star}, u^{\star}\right)$ merupakan solusi optimum. Jika $H$ strictly concave, maka $\left(x^{\star}, u^{\star}\right)$ merupakan solusi tunggal.

\section{Teorema 3.6 (The Arrow Sufficiency Theorem).}

Misalkan $\left(x^{\star}, u^{\star}\right)$ merupakan pasangan admissible. Jika $\exists p(t)=\left(p_{1}, p_{2}, \ldots, p_{n}\right)$ dan $p_{0}=1$ sehingga

$$
\begin{gathered}
\left.H\left(x^{\star}, u^{\star}\right), p, t\right) \geq H\left(x^{\star}, u, p, t\right), \quad \forall t \in[0, T] \quad \text { dan } \forall u \in \mathcal{U}, \\
\hat{H}(x, p, t)=\max _{u \in \mathcal{U}} H(x, u, p, t) \text { dan } \hat{H}(x, p, t) \text { concave, }
\end{gathered}
$$

maka $\left(x^{\star}, u^{\star}\right)$ merupakan solusi optimum. Jika $\hat{H}(x, p, t)$ strictly concave maka $x^{\star}$ tunggal, sedangkan $u^{\star}$ belum tentu tunggal.

\subsection{Current-Value Hamiltonian}

Penggunaan teori kontrol optimum dalam masalah ekonomi,fungsi integrand $f_{0}$ sering memuat faktor diskon $e^{-\rho t}$. Dengan demikian, fungsi integrand $f_{0}$ secara umum dapat dituliskan menjadi

$$
f_{0}(t, x, u)=G(t, x, u) e^{-\rho t}
$$

sehingga masalah kontrol optimum menjadi memaksimumkan fungsi nilai

$$
\max V=\int_{0}^{T} G(t, x, u) e^{-\rho t} d t
$$

terhadap kendala $\dot{x}=f(t, x, u)$ ditambah dengan syarat batas. Dengan definisi standar, fungsi Hamilton dapat dituliskan dalam bentuk

$$
H(t, x, u, p)=G(t, x, u) e^{-\rho t}+p(t) f(t, x, u)
$$

Akan tetapi, karena prinsip maksimum menggunakan turunan fungsi Hamilton terhadap $x$ dan $u$, dengan hadirnya faktor diskon akan menambah kerumitan penentuan turunan 
tersebut. Untuk itu, dikenalkan fungsi Hamilton baru, yang sering disebut dengan CurrentValue Hamiltonian. Untuk menerapkan konsep current-value Hamiltonian, diperlukan konsep current-value pengali Lagrange, atau current value fungsi adjoint. Misalkan $m(t)$ menyatakan current-value pengali Lagrange, yang didefinisikan dengan $m(t)=p(t) e^{\rho t}$, yang berimplikasi $p(t)=m(t) e^{-\rho t}$. Sehingga fungsi current-value Hamiltonian, yang dinotasikan dengan $H_{c}$, dapat dituliskan menjadi

$$
H_{c} \equiv H e^{\rho t}=G(t, x, u)+m(t) f(t, x, u)
$$

Perhatikan bahwa, $H_{c}$, sebagaimana yang diinginkan, sudah tidak memuat faktor diskon. Juga, perhatikan bahwa $H \equiv H_{c} e^{-\rho t}$. Kemudian penerapan prinsip maksimum Pontryagin terhadap $H_{c}$, harus disesuaikan. Karena $u$ yang memaksimumkan $H$ juga akan memaksimumkan $H_{c}$, jadi

$$
\max _{u} H_{c}, \quad \forall t \in[0, T]
$$

Persamaan state yang muncul dalam sistem kanonik, aslinya adalah $\dot{x}(t)=\partial H / \partial p$. Karena

$$
\frac{\partial H}{\partial p}=f_{0}(t, x, u)=\frac{\partial H_{c}}{\partial m},
$$

maka persamaan ini disesuaikan menjadi

$$
\dot{x}(t)=\frac{\partial H_{c}}{\partial m}
$$

Persamaan untuk peubah adjoint yang muncul dalam sistem kanonik, aslinya adalah dalam bentuk $\dot{p}(t)=-\partial H / \partial x$. Pertama-tama, transformasikan masing-masing suku dalam bentuk yang melibatkan peubah adjoint baru, $m(t)$, kemudian hasilnya disamakan. Untuk suku kiri,

$$
\dot{p}(t)=\dot{m}(t) e^{-\rho t}-\rho m(t) e^{-\rho t}
$$

Dengan memanfaatkan definisi $H$, suku kanan dapat dituliskan kembali dalam bentuk

$$
-\frac{\partial H}{\partial x}=-\frac{\partial H_{c}}{\partial x} e^{-\rho t}
$$

Dengan menyamakan kedua persamaan tersebut di atas, menghasilkan

$$
\dot{m}(t)=-\frac{\partial H_{c}}{\partial x}+\rho m(t) .
$$


Tersisa sekarang adalah memeriksa kondisi(syarat) batas. Untuk syarat batas $p(T)=0$, memberikan syarat batas yang sesuai, yaitu $m(T) e^{-\rho T}=0$. Untuk syarat batas $[H]_{t=T}=0$, menghasilkan syarat batas yang sesuai $\left[H_{c} e^{-\rho t}\right]_{t=T}=0$.

\subsection{Beberapa contoh masalah nyata kontrol optimum}

1. Portfolio Selection and Consumption Model

Model ini pertama kali dikembangkan oleh R.Merton, dengan merumuskan persamaan diferensial stokastik untuk pertumbuhan kekayaan investor, yang dikenal dengan sebutan budget equation. Misalkan $W(t)$ menyatakan jumlah kekayaan investor pada waktu $t$, dan yang dapat diinvestasikan pada 2 aset, yaitu pada aset bebas resiko dan aset beresiko. Masalah pemilihan portofolio dan konsumsi optimal untuk investor yang hidup $T$ tahun diformulasikan sebagai berikut :

$$
\max _{u, C} J[u, C]=E\left\{\int_{0}^{T} U(C(t), t) d t+B(W(T), T)\right\}
$$

dengan kendala persamaan kekayaan

$$
\begin{aligned}
d W(t) & =(1-u) W r d t+u W(\alpha d t+\sigma d B(t))-C d t \\
W(0) & =W_{0}
\end{aligned}
$$

dengan $W_{0}>0, u(t)$ menyatakan proporsi kekayaan yang diinvestasikan pada aset beresiko pada waktu $t$ dengan $0 \leq u(t) \leq 1, C(t),(\geq 0)$, menyatakan tingkat konsumsi pada waktu $t$. Fungsi utilitas $U$ diasumsikan strictly concave dan bequest function $B$ juga concave.

2. Konsumsi versus Investasi

Perhatikan masalah kontrol optimum yang memaksimumkan fungsional objektif $J$ sebagai berikut :

$$
\max J(u(t))=\int_{0}^{T} U(1-u(t)) d t
$$

terhadap kendala

$$
\dot{x}(t)=u(t), \quad x(0)=x_{0}, \quad x(T) \geq x_{T}, \quad u(t) \in[0, T], \quad x_{0}<x_{T}<x_{0}+T .
$$


Masalah di atas mempunyai interpretasi ekonomi sebagai berikut : Negara menerima bantuan tetap sebesar 1 satuan ekonomi. Peubah $x(t)$ dapat menyatakan tingkat infrastruktur pada waktu $t$, peubah $u(t)$ menyatakan proporsi dari bantuan yang dialokasikan untuk investasi pada infrastruktur pada waktu $t$, sedangkan $1-u(t)$ menyatakan bagian dari bantuan yang dialokasikan untuk konsumsi. Fungsi $U$ menyatakan fungsi utilitas. Periode perencanaan adalah untuk jangka waktu $[0, T], \quad x(T) \geq x_{T}$ menyatakan bahwa pada akhir periode perencanaan tingkat infrastruktur sekurangkurangnya berada pada tingkat $x_{T}$. Masalah perencanaan adalah menentukan berapa banyak dari bantuan yang harus dialokasikan untuk investasi pada infrastruktur supaya tingkat utilitas maksimum.

\section{A two-sector model}

Perhatikan suatu ekonomi yang terdiri atas dua sektor, dimana sektor 1 memproduksi investment goods sedangkan sektor 2 memproduksi consumption goods. Misalkan $x_{i}, i=1,2$, menyatakan jumlah produksi sektor $i$ per satuan waktu, dan misalkan $u(t)$ menyatakan proporsi investasi yang dialokasikan pada sektor 1. Kita asumsikan $\dot{x_{1}}=a u x_{1}$ dan $\dot{x_{2}}=a(1-u) x_{1}$, dengan a merupakan suatu konstanta positif. Kenaikan jumlah produksi per satuan waktu dalam setiap sektor diasumsikan proporsional terhadap besarnya investasi yang dialokasikan pada sektor tersebut. Dengan pemahaman tersebut, kontrol $0 \leq u(t) \leq 1$, dan periode perencanaan dimulai pada $t=0$, sehingga $x_{1}(0)$ dan $x_{2}(0)$ diketahui besarnya. Untuk situasi seperti ini, berbagai macam masalah kontrol optimum dapat diinvestigasi. Salah satunya adalah masalah memaksimumkan total konsumsi pada periode waktu $[0, T]$.

Masalah kontrol optimum tersebut, secara matematis dituliskan seperti berikut :

$$
\max J(u)=\int_{0}^{T} x_{2}(t) d t
$$

dengan kendala :

$$
\begin{array}{cll}
\dot{x_{1}}=\text { aux }_{1}, & x_{1}(0)=x_{1}^{0}, & x_{1}(T) \text { bebas } \\
\dot{x_{2}}=a(1-u) x_{1}, & x_{2}(0)=x_{2}^{0}, & x_{2}(T) \text { bebas }
\end{array}
$$

4. Model pertumbuhan ekonomi neo klasik 
Menentukan proporsi menabung sehingga memaksimumkan jumlah konsumsi per kapita dan memenuhi persamaan dasar model pertumbuhan ekonomi neo klasik, yang secara matematis diformulasikan sebagai berikut :

$$
\begin{aligned}
\max _{0 \leq s_{t} \leq 1} J\left(s_{t}\right) & =\int_{0}^{\infty}\left(1-s_{t}\right) f\left(k_{t}\right) e^{-\rho t} d t \\
\text { Dengan kendala } \dot{k}_{t} & =s_{t} f\left(k_{t}\right)-\lambda k_{t}, \quad k_{t} \geq 0,
\end{aligned}
$$

dimana $k_{t}=$ kapital per tenaga kerja, $s_{t}=$ proporsi menabung, $f\left(k_{t}\right)=$ output per kapita.

5. Masalah Konsumsi dan Investasi Model Waktu Diskret-Kontinu

Formulasi masalah konsumsi dan investasi untuk investor yang memiliki dua instrumen investasi, yaitu aset bebas resiko dan aset beresiko adalah sebagai berikut : Masalah kontrol optimum untuk investor diberikan oleh

$$
U\left(x_{0}\right) \equiv \max _{(T, W, V, C) \in \mathcal{U}} E\left[\int_{0}^{\infty} e^{-\delta t} u\left(C_{t}\right) d t\right]
$$

dengan kendala, untuk $n=1,2,3, \ldots$,

$$
x_{\tau_{n+1}}=(1-\varepsilon)\left[x_{\tau_{n}}-W_{\tau_{n}}\right] e^{r T_{n}}+V_{\tau_{n}}\left[\Gamma_{n+1}-e^{r T_{n}}\right],
$$

dan $M_{t} \geq 0$, dan $x_{\tau_{n+1}} \geq 0$.

Masalah kontrol optimum di atas diselesaikan dengan terlebih dahulu melakukan modifikasi, menjadi seperti berikut

$$
U\left(x_{0}\right)=\max _{\{T \in \mathcal{T}, W \in \mathcal{W}, V \in \mathcal{V}\}} E\left[\sum_{n=1}^{\infty} e^{-\delta \tau_{n}} Q_{n}^{\nu} \frac{1}{\gamma} W_{\tau_{n}}^{\gamma}\right],
$$

terhadap kendala, untuk $n=1,2,3, \ldots$,

$$
x_{\tau_{n+1}}=(1-\varepsilon)\left[x_{\tau_{n}}-W_{\tau_{n}}\right] e^{r T_{n}}+V_{\tau_{n}}\left[\Gamma_{n+1}-e^{r T_{n}}\right] \geq 0,
$$

dimana $T_{n}=\tau_{n+1}-\tau_{n}$.

Pengaplikasian prinsip keoptimalan Bellman pada $U$, menghasilkan

$$
U\left(x_{\tau_{n}}\right)=\max _{\left\{T_{n}, W_{\tau_{n}}, V_{\tau_{n}}\right\}}\left\{Q_{n}^{\nu} \frac{1}{\gamma} W_{\tau_{n}}^{\gamma}+e^{-\delta T_{n}} E\left[U\left(x_{\tau_{n+1}}\right) \mid \mathcal{H}_{\tau_{n}}\right]\right\},
$$

terhadap kendala, untuk $n=1,2,3, \ldots$,

$$
x_{\tau_{n+1}}=(1-\varepsilon)\left[x_{\tau_{n}}-W_{\tau_{n}}\right] e^{r T_{n}}+V_{\tau_{n}}\left[\Gamma_{n+1}-e^{r T_{n}}\right] \geq 0 .
$$


6. Optimal Monetary Policy

Untuk aplikasi dalam masalah ekonomi, perhatikan model Optimal Monetary Policy yang dikembangkan oleh Peterson dan Lerner (1971). Sistem yang digunakan berdasarkan studi empris Friedman yang sudah dimodifikasi, yaitu :

$$
\frac{a^{2}}{2} \frac{d^{2} x(t)}{d t^{2}}+a \frac{d x(t)}{d t}+x(t)=u(t)
$$

dengan $x(t)$ menyatakan proportional rate of growth of money income, $u \equiv m+b \dot{m}$ dimana $m \equiv(1 / M)(d M / d t)$ merupakan proportional rate of change of money supply $M(t)$ dan $b$ suatu konstanta. $a=$ konstanta yang merepresentasikan the length of business cycle. Dengan mendefinisikan $x=x_{1}, \dot{x}=x_{2}, \frac{d^{2} x(t)}{d t^{2}}=\dot{x}_{2}$, maka masalah di atas dapat dituliskan dalam bentuk sistem

$$
\dot{x}(t)=A x(t)+b u(t)
$$

Objektif dari otoritas moneter adalah untuk mencapai rate of growth of national income yang stabil pada waktu mendatang, yaitu $x(T)=x_{1 T} ; \dot{x}(T)=0$ dengan cara menggunakan optimal money supply policy. Masalah ini sama saja dengan meminimumkan fungsional objektif $J=\int_{0}^{T} d t$. Dengan demikian, masalah menjadi masalah kontrol optimum yang meminimumkan fungsional objektif

$$
J(u)=\int_{0}^{T} d t
$$

dengan kendala

$$
\dot{x}(t)=A x(t)+b u(t)
$$

dengan $x(0) \equiv\left(x_{1}(0), x_{2}(0)\right)=\left(x_{10}, x_{20}\right)$ diberikan dan $x(T) \equiv\left(x_{1}(T), x_{2}(T)\right)=$ $\left(x_{1 T}, 0\right),|u| \leq 0.1$

\subsection{Peubah Kontrol Berbatas}

Perhatikan masalah kontrol optimum yang memaksimumkan fungsional objektif

$$
J[u(t)]=\int_{0}^{T} f_{0}(x(t), u(t), t) d t
$$


dengan kendala $\dot{x}(t)=f(x(t), u(t), t)$, dan kontrol $u$ memenuhi kendala $g_{i}(x(t), u(t), t) \geq 0$, dan $x(t)$ dan $\dot{x}(t) \in R^{n}$ dan $u(t) \in R^{k}$. Masalah kontrol optimum di atas dapat ditransformasikan menjadi masalah dengan kendala persamaan. Hal ini dilakukan dengan membuat peubah semu $\dot{\zeta}$ sehingga $g_{i}(x, u, t)-\dot{\zeta}_{i}^{2}=0$. Definisikan fungsi $F$ dengan

$$
F=H-p \dot{x}+\lambda\left(g-\dot{\zeta}_{i}^{2}\right)
$$

Teorema 3.7 Misalkan $u^{\star}(t)$ merupakan kontrol admissible yang mentransfer state awal $x(0)$ kepada state target $(x(T), T)$ dan memberikan ekstremal untuk fungsional J. Definisikan fungsi $\hat{H}=p_{0} f_{0}+p f+\lambda g$. Supaya kontrol $u^{\star}(t)$ adalah kontrol yang optimal, maka adalah perlu untuk terdapatnya suatu pasangan $p_{0}, p(t)$ dan $\lambda(t)$ pada interval waktu $[0, T]$ sehingga

1. $\left(p_{0}, p(t)\right) \neq(0,0)$,

2. $\dot{x}(t)=\hat{H}_{p}$,

3. $\dot{p}(t)=-\hat{H}_{x}$,

4. $\hat{H}_{u}=0$, atau $\hat{H}\left(x^{\star}, u^{\star}, p_{0}, p\right) \geq \hat{H}\left(x^{\star}, u, p_{0}, p\right)$

5. $\lambda_{i} \geq 0, \quad g_{i} \geq 0$, dan $\lambda_{i} g_{i}=0$.

Pada waktu terminal $T$ berlaku $\hat{H}(T) \delta T+\left.F_{\dot{Z}} \delta Z\right|_{T}=0$.

\subsubsection{Masalah Kontrol Optimum dengan Peubah Keadaan Berba- $\operatorname{tas}$}

Masalah kontrol optimum untuk tipe ini adalah memaksimumkan fungsional objektif $J$ yang diberikan oleh

$$
J[u(t)]=\int_{0}^{T} f_{0}(x(t), u(t), t) d t
$$

dengan kendala $\dot{x}(t)=f(x(t), u(t), t), \quad$ dan $x(t) \geq \varphi(t), x(t), \quad \dot{x}(t) \in R^{n}$ dan $u(t) \in R^{k}$. Definisikan $Z^{2} \equiv x(t)-\varphi(t)$. Masalah kontrol optimum di atas ditransformasikan menjadi

$$
J[u(t)]=\int_{0}^{T} f_{0}(x(t), u(t), t) d t
$$


dengan kendala $\dot{x}(t)=f(x(t), u(t), t)$, dan $g(x)-Z^{2}=0$, dengan $g(x)=x(t)-\varphi(t)$. Kemudian definisikan $F=H-p \dot{x}+\lambda\left(g-Z^{2}\right)$. Dengan menentukan persamaan Euler dari $F$, maka diperoleh fungsi Hamiltonian yang dilengkapi :

$$
\hat{H}=f_{0}(x, u, t)+p \cdot f(x, u, t)+\lambda g(x, t)
$$

dengan $\lambda$ merupakan pengali Lagrange. Untuk $g>0$ maka $\lambda=0$, dan untuk $g \equiv 0$, maka $\lambda \neq 0$.

\subsubsection{Masalah Kontrol Optimum dengan Kendala Persamaan}

Hadirnya kendala persamaan pada masalah kontrol optimum diperlakukan sama seperti pada masalah kalkulus variasi.

Perhatikan masalah kontrol optimum memaksimumkan fungsional objektif $J$

$$
\max J[u(t)]=\int_{0}^{T} f_{0}(x(t), u(t), t) d t
$$

dengan kendala

$$
\begin{aligned}
\dot{x}_{i}(t) & =f(x(t), u(t), t), \quad(1 \leq i \leq n) \\
\psi_{i}(x, u, t) & =0, \quad(1 \leq i \leq q \leq n) \\
I_{i}(x) & \equiv \int_{0}^{T} \phi_{i}(x, u, t) d t-l_{i}=0, \quad(1 \leq i \leq m)
\end{aligned}
$$

dengan $l_{i}=$ konstanta untuk $(i=1,2, \ldots, m), \quad f_{0}, f_{i}$ dan $\phi_{i}$ diasumsikan fungsi "well behaved". Masalah tersebut merupakan masalah kendala isoperimetric dan kendala titik. Seperti pada kalkulus variasi, kita definisikan fungsi $y_{i}$, dimana

$$
\begin{gathered}
y_{i} \equiv \int_{0}^{t} \phi_{i}(x, u, t) d t, \quad(1 \leq i \leq m) \\
y_{i}(0)=0 ; \quad y_{i}(T)=l_{i}, \quad \dot{y}_{i}(t)=\phi_{i}(x, u, t), \quad(1 \leq i \leq m) .
\end{gathered}
$$

Dengan demikian, kendala isoperimetric sudah ditransfer menjadi kendala dalam bentuk persamaan diferensial. Selanjutnya, trayektori optimal harus memenuhi kendala titik $\psi_{i}(x, u, t)=$ 0 , dengan asumsi bahwa matrik Jacobian $\left[\partial \psi_{i} / \partial u_{j}\right]$ mempunyai rank $q$, dengan kata lain $\psi_{i}=0$ merupakan persamaan yang saling bebas. Definisikan fungsi Hamiltonian $\hat{H}$ dengan

$$
\hat{H}=f_{0}(x, u, t)+p f(x, u, t)+\lambda \phi(x, u, t)+\mu \psi(x, u, t)
$$


Teorema 3.8 Jika $u^{\star}(t)$ memaksimumkan $J$ maka terdapat $p(t), \quad \lambda$ dan $\mu$ yang tidak semuanya nol sehingga

1. $\lambda_{i}$ merupakan konstanta

2. $p(t)$ kontinu dan memenuhi

(a) $\dot{x}(t)=f(x(t), u(t), t)$

(b) $\dot{p}=-\hat{H}_{x}$

(c) $\hat{H}_{u}=0$

(d) $\psi=0$

3. $\hat{H}\left(x, u^{\star}, p, \mu, t\right) \geq \hat{H}(x, u, p, \mu, t)$ untuk semua $u^{\star}(t)$ yang memenuhi $\psi\left(x, u^{\star}, t\right)=0$.

\subsubsection{Masalah Kontrol Optimum dengan Peubah Kontrol Berba- $\operatorname{tas}$}

Perhatikan masalah kontrol optimum yang memaksimumkan fungsional objektif

$$
J[u(t)]=\int_{0}^{T} f_{0}(x(t), u(t), t) d t
$$

dengan kendala

$$
\begin{aligned}
\dot{x}(t) & =f(x(t), u(t), t) \\
g_{i}(x, u, t) & \geq 0 \quad(1 \leq i \leq q \leq r \leq n)
\end{aligned}
$$

Kendala ketaksamaan ditransfer menjadi kendala persamaan dengan mengenalkan peubah semu $\dot{\xi}$ sehingga

$$
g_{i}(x, u, t)-\dot{\xi}_{i}^{2}=0, \quad(1 \leq i \leq q .)
$$

Teorema 3.9 Misalkan $u^{\star}$ merupakan kontrol admissible yang mentransfer sistem dari state awal $\left(x_{0}, 0\right)$ kepada state tujuan $(x(T), T)$. Supaya kontrol $u^{\star}(t)$ merupakan kontrol optimum, maka terdapat $p(t) \neq 0$ dan $\lambda(t)$ sehingga: 
1. $\dot{x}=\bar{H}_{p}$

2. $\dot{p}=-\bar{H}_{x} \equiv-\left(H_{x}+\lambda g_{x}\right)$

3. $\bar{H}_{u}=0 \Longleftrightarrow H_{u}+\lambda g_{u}=0, \quad \lambda_{i} \geq 0, g_{i} \geq 0$ dan $\lambda_{i} g_{i}=0$.

dengan Hamiltonian $\bar{H}=f_{0}+p f+\lambda g \equiv H+\lambda g$.

Catatan : Apabila kendala dari peubah kontrol dalam bentuk $m_{i} \leq u_{i} \leq M_{i}, \quad m_{i}, M_{i}$ bilangan yang diberikan, maka

$$
\frac{\partial H}{\partial u_{i}}\left\{\begin{array}{l}
\geq 0, \text { jika } u_{i}^{\star}=M_{i} \\
=0, \text { jika } m_{i}<u_{i}<M_{i} \\
\leq 0, \text { jika } u_{i}^{\star}=m_{i}
\end{array}\right.
$$

Dengan demikian, kendala $g$ menjadi :

$$
\begin{aligned}
g_{i} & \equiv M_{i}-u_{i}, \quad(i=1,2, \ldots, r) \\
g_{j} & \equiv u_{j}-m_{j}, \quad(j=r+1, \ldots, 2 r) .
\end{aligned}
$$

Atau,

$$
1-u-\dot{\zeta}_{1}^{2}=0, \quad u+1-\dot{\zeta}_{1}^{2}=0 .
$$

\subsection{Kontrol Optimum Linier}

Masalah kontrol optimum linier adalah masalah kontrol optimum dimana fungsi Hamiltonian merupakan fungsi linier dari peubah kontrol. Sifat kelinieran tersebut dapat muncul pada Hamiltonian karena fungsi objektif dan atau fungsi kendala merupakan fungsi linier dari peubah kontrol.

Secara umum, fungsi Hamiltonian dalam bentuk linier dapat dituliskan dalam bentuk berikut :

$$
H \equiv \psi(x, p, t)+\sigma(x, p, t) u(t)
$$

dengan $\sigma(x, p, t)$ menyatakan kumpulan koefisien dari peubah kontrol $u(t)$ yang disebut sebagai switching function, dan $\psi(x, p, t)$ merupakan kumpulan koefisien yang tidak memuat 
$u(t)$. Secara umum, untuk kontrol yang tidak memiliki batasan, kontrol ekstremum tidak ada. Kalau kontrol memiliki batas, maka kontrol ekstremal tersebut akan terdapat pada batas-batasnya.

Misalkan kontrol $u$ berbatas, misalnya $m_{i} \leq u_{i} \leq M_{i}, \quad \forall i$, dengan $m_{i}$ dan $M_{i}$ berturutturut merupakan nilai minimum dan maksimum yang dapat dicapai oleh $u_{i}$. Apabila $m_{i}$ dan $M_{i}$ merupakan konstanta, maka dapat ditulis sebagai $-1 \leq u_{i} \leq 1$. Dengan menerapkan prinsip maksimum Pontryagin pada masalah seperti ini, maka diperoleh kontrol optimum $u_{i}^{\star}$ berikut :

$$
u_{i}^{\star}=\left\{\begin{array}{ccc}
1\left(\operatorname{atau} M_{i}\right) & \text { jika } & \sigma_{i}>0 \\
-1\left(\operatorname{atau} m_{i}\right) & \text { jika } & \sigma_{i}<0
\end{array}\right.
$$

Jadi, kalau kontrol $u(t)$ munculnya linier dalam fungsi Hamiltonian dan tiap komponen $u_{i}$ memiliki batas, maka kontrol optimum $u_{i}^{\star}(t)$ tak kontinu : loncat dari nilai minimum ke nilai maksimum atau sebaliknya sebagai respons terhadap perubahan tanda dari $\sigma_{i}$. Dengan alasan ini, maka $\sigma(x, p, t)$ disebut sebagai switching function dan kontrol $u_{i}^{\star}$ disebut sebagai kontrol bang-bang.

Perhatikan sistem persamaan diferensial berikut :

$$
\dot{x}(t)=A x(t)+B u(t)
$$

dengan $x$ adalah vektor dimensi- $n, u$ vektor dimensi- $r, A$ adalah matrik ukuran $n x n$ dan $B$ adalah matrik ukuran $n x r,\left|u_{i}\right| \leq 1,(1 \leq i \leq r)$. Kontrol harus dipilih sehingga mentransfer sistem dari posisi awal $x_{0}$ kepada state akhir atau tujuan $x(T)=0$ dalam waktu yang minimum. Hal ini berarti bahwa fungsional objektif adalah dalam bentuk meminimumkan waktu, yaitu : $\min J(u)=\int_{0}^{T} d t$. Fungsi Hamiltonian diberikan oleh

$$
\begin{aligned}
H & \equiv 1+p^{\prime} A x+p^{\prime} B u \\
\dot{p} & =-H_{x}=-A^{\prime} p
\end{aligned}
$$

Switching function $\sigma \equiv p^{\prime} B \equiv p^{\prime}\left[b_{1}, b_{2}, \ldots, b_{n}\right]$ dengan $b_{i}$ menyatakan kolom ke- $i,(1 \leq i \leq r)$ dari matrik $B$. Karena $\left|u_{i}\right| \leq 1, \quad \forall i$ dan $H$ fungsi linier dari $u$, maka kontrol diperoleh, yaitu 


$$
u_{i}^{\star}= \begin{cases}1 & \text { untuk } \sigma_{i} \equiv p^{\prime} b_{i}>0 \text { : bang bang } \\ -1 & \text { untuk } \sigma_{i} \equiv p^{\prime} b_{i}<0 \text { : bang bang } \\ \text { undetermined } & \text { untuk } p^{\prime} b_{i}=0: \text { singular }\end{cases}
$$

Untuk kasus di atas, tidak mungkin terjadi $p=0$ sehingga $p^{\prime} b_{i}=0$. Jadi, kontrol singular tidak mungkin terjadi. Akibatnya, kontrolnya adalah bang-bang. Satu hal yang perlu diingat bahwa dalam masalah meminimumkan waktu, kontrol optimum tidak selalu ada. Apabila tidak ada kontrol admissible yang membawa sistem ke target yang diinginkan, maka kontrol optimum tidak ada.

Dalam masalah kontrol optimum, 3 teorema berikut sangat bermanfaat (teorema ini dibuktikan oleh Pontryagin).

1. Existence Theorem : Apabila matrik $A$ merupakan matrik stabil (artinya, semua nilai eigen atau nilai karakteristiknya mempunyai bagian riel yang positif), maka untuk titik $x_{0}$, terdapat kontrol optimum yang mentransfer $x_{0}$ ke titik origin atau titik asal.

2. Uniqueness Theorem : Jika kontrol optimum ada, maka kontrol tersebut tunggal.

3. Switching Theorem : Misal nilai eigen atau nilai karakteristik dari matrik $A$ semuanya bernilai riel. Maka ada kontrol optimum yang tunggal. Tiap-tiap kontrol $u_{i}, \quad(1 \leq i \leq r)$, yang merupakan konstan bagian, hanya bernilai maksimum dan minimum, dan mengalami switching tidak lebih dari $n-1$.

Contoh : Optimal Monetary Policy Untuk aplikasi dalam masalah ekonomi, perhatikan model Optimal Monetary Policy yang dikembangkan oleh Peterson dan Lerner (1971). Sistem yang digunakan berdasarkan studi empris Friedman yang sudah dimodifikasi, yaitu :

$$
\frac{a^{2}}{2} \frac{d^{2} x(t)}{d t^{2}}+a \frac{d x(t)}{d t}+x(t)=u(t)
$$

dengan $x(t)$ menyatakan proportional rate of growth of money income, $u \equiv m+b \dot{m}$ dimana $m \equiv(1 / M)(d M / d t)$ merupakan proportional rate of change of money supply $M(t)$ dan $b$ suatu konstanta. $a=$ konstanta yang merepresentasikan rentang siklus bisnis, atau the length of business cycle. 
Dengan mendefinisikan

$$
x=x_{1}, \dot{x}=x_{2}, \frac{d^{2} x(t)}{d t^{2}}=\dot{x}_{2},
$$

maka masalah di atas dapat dituliskan dalam bentuk sistem

$$
\dot{x}(t)=A x(t)+b u(t)
$$

Objektif dari otoritas moneter adalah untuk mencapai rate of growth of national income yang stabil pada waktu mendatang, yaitu $x(T)=x_{1 T} ; \dot{x}(T)=0$ dengan cara menggunakan optimal money supply policy. Masalah ini sama saja dengan meminimumkan fungsional objektif $J=\int_{0}^{T} d t$. Dengan demikian, masalah menjadi masalah kontrol optimum yang meminimumkan fungsional objektif

$$
J(u)=\int_{0}^{T} d t
$$

dengan kendala

$$
\dot{x}(t)=A x(t)+b u(t)
$$

dengan $x(0) \equiv\left(x_{1}(0), x_{2}(0)\right)=\left(x_{10}, x_{20}\right)$ diberikan dan $x(T) \equiv\left(x_{1}(T), x_{2}(T)\right)=\left(x_{1 T}, 0\right)$, $|u| \leq 0.1$ Masalah ini merupakan masalah kontrol optimum linier, dan Hamiltonian diberikan oleh

$$
H \equiv 1-\left(2 p_{2} / a^{2}\right) x_{1}+\left(p_{1}-2 p_{2} / a\right) x_{2}+\left(2 / a^{2}\right) p_{2} u
$$

Switching function $\sigma=\left(2 / a^{2}\right) p_{2}$ dan optimal policy diberikan oleh

$$
u^{\star}(t)= \begin{cases}0,1 & \text { jika } p_{2}(t)>0 \\ -0,1 & \text { jika } p_{2}(t)<0\end{cases}
$$

Kalau kontrol optimum $u^{\star}(t)$ sudah diperoleh, maka $m^{\star}$ dan $M^{\star}$ dapat ditentukan. Karena $\dot{p}=-H_{x}=-A^{\prime} p$ dan nilai eigen dari matrik $-A^{\prime}$ adalah $\mu=1 / a \pm i / a$, maka

$$
p_{2}(t)=e^{t} / a\left(c_{1} \cos t / a+c_{2} \sin t / a\right) .
$$

Fungsi $p_{2}$ ini yang bertindak sebagai switching function tidak pernah bernilai nol. State dari system diperoleh dengan menyelesaikan $\dot{x}(t)=A x(t) \pm 0,1 b$. Karena nilai eigen dari $A$ adalah $\mu=-1 / a \pm i / a$, maka solusi $x$ adalah

$$
\begin{aligned}
& x_{1}(t)= \pm 0,1+e^{-t / a}\left(c_{3} \cos t / a+c_{4} \sin t / a\right), \text { untuk } u= \pm 0,1 \\
& x_{2}(t)=1 / a e^{-t / a}\left\{\left(c_{4}-c_{3}\right) \cos t / a-\left(c_{3}+c_{4}\right) \sin t / a\right\}
\end{aligned}
$$




\subsection{Soal-soal Latihan}

\subsubsection{Soal-soal Kalkulus Variasi}

1. Tentukan ekstremum, jika ada, dari fungsional berikut:

(a) $J(x)=\int_{0}^{1}\left(t x+2 \dot{x}^{2}\right) d t, \quad x(0)=1, \quad x(1)=2$.

(b) $J(x)=\int_{0}^{1} t x \dot{x} d t, \quad x(0)=0, \quad x(1)=1$.

(c) $J(x)=\int_{0}^{2}\left(2 x e^{t}+x^{2}+\dot{x}^{2}\right) d t, \quad x(0)=2, \quad x(2)=2 e^{2}+e^{-2}$.

(d) $J(x)=\int_{0}^{2}\left(x^{2}+t^{2} \dot{x}\right) d t, \quad x(0)=0, \quad x(2)=2$.

(e) $J(x)=\int_{0}^{2}\left(12 t x+\dot{x}^{2}\right) d t, \quad x(0)=0, \quad x(2)=8$.

(f) $J(x)=\int_{0}^{5}\left(t+x^{2}+3 \dot{x}\right) d t, \quad x(0)=0, \quad x(5)=3$.

(g) $J(x)=\int_{0}^{1}\left(x+x \dot{x}+\dot{x}+(1 / 2) \dot{x}^{2}\right) d t, \quad x(0)=2, \quad x(1)=5$.

2. Tentukan ekstremum dari fungsional :

$$
J(x)=\int_{0}^{1}\left(1+\ddot{x}^{2}\right) d t, \quad x(0)=0, \dot{x}(0)=1, \quad x(1)=1, \quad \dot{x}(1)=1 .
$$

3. Diberikan fungsional objektif $J(x)=\int_{0}^{T}\left(x+\dot{x}^{2}\right) d t$.

(a) Tentukan persamaan Euler dan solusi umum.

(b) Tentukan solusi dari persamaan Euler yang memenuhi $x(0)=x_{0}$, dan $x(T)=x_{T}$.

(c) Tentukan ekstremum untuk fungsional objektif apabila diberikan $x(0)=2$.

4. Perhatikan masalah meminimumkan fungsional objektif $J[x(t)]$ yang didefinisikan oleh

$$
J[x(t)]=\int_{0}^{T}\left[t \dot{x}(t)+\dot{x}^{2}(t)\right] d t .
$$

(a) Tuliskan persamaan Euler dan solusi umumnya.

(b) Tentukan solusi yang memenuhi kendala $x(0)=x_{0}, x(T)$ bebas dan $T=1$.

(c) Tentukan solusi yang memenuhi kendala $x(0)=5, x(T)$ bebas dan $T=2$.

(d) Tentukan solusi yang memenuhi kendala $x(0)=1, \quad x(1) \geq 1$. 
5. Diberikan fungsional objektif

$$
J(x)=\int_{0}^{T}\left(t x+x^{2}+\dot{x}^{2}\right) d t .
$$

(a) Turunkan persamaan Euler untuk masalah di atas dan berikan solusi umumnya.

(b) Tentukan solusi persamaan Euler apabila $x(0)=0$ dan $x(2)=e^{2}$.

6. Diberikan fungsional objektif $\int_{0}^{T}\left(x^{2}+\dot{x}^{2}\right) d t$.

(a) Tentukan persamaan Euler serta solusi umumnya.

(b) Tentukan solusi persamaan Euler sedemikian sehingga $x(0)=x_{0}$ dan $x(T)=x_{T}$.

(c) Tentukan ekstremum apabila $x(0)=1, T=1, x(1)$ bebas.

(d) Tentukan ekstremum apabila $x(0)=0 \quad T=1$, dan $x(1) \geq 1$.

(e) Tentukan ekstremum apabila $x(0)=0, \quad x(T)=T+1,(T>1)$.

7. Tentukan ekstremum yang memberikan minimum fungsional objektif

$$
J(x)=\int_{0}^{1}\left(\dot{x}_{1}^{2}+\dot{x}_{2}^{2}+\dot{x}_{1} \dot{x}_{2}\right) d t, \quad x_{1}=x_{2}=0, \quad x_{1}=1, \quad x_{2} \geq 1 .
$$

8. Tentukan ekstremum untuk masalah pertumbuhan yang memaksimumkan fungsional objektif

$$
J(K)=\int_{0}^{T} \frac{1}{1-\nu}(b K-\dot{K})^{1-\nu} e^{-\rho t} d t, \quad K(0)=K_{0}, \quad K(T)=K_{T} .
$$

9. Tentukan ekstremum untuk masalah meminimumkan fungsional

$$
J(x)=\int_{0}^{T}\left(x^{2}+\dot{x}^{2}\right) d t, \quad x(0)=0, \quad x(T)=1, \quad T \in[1,2] .
$$

10. Tentukan ekstremum yang meminimumkan fungsional

$$
J(x)=\int_{0}^{T}\left(x^{2}+\dot{x}^{2}+3\right) d t, \quad x(0)=0, \quad x(T)=1, \quad T \in[1 / 2, \infty) .
$$

11. Tentukan ekstremum yang memberikan minimum fungsional objektif

$$
J(x)=\int_{0}^{\pi / 2}\left(\dot{x}_{1}^{2}+\dot{x}_{2}^{2}+2 x_{1} x_{2}\right) d t, \quad x_{1}(0)=0=x_{2}(0),
$$

dan (a) $x_{1}(\pi / 2)=1, \quad$ (b) $\quad x_{2}(\pi / 2)$ bebas. 
12. Selesaikan masalah memaksimumkan fungsional objektif $J(x)=\int_{0}^{5} \dot{x}^{2} d t$ dengan kendala $x(0)=1, x(5)=11$ dan $\int_{0}^{5}(1+x) d t=5$.

13. Diberikan fungsional objektif $J(x)=\int_{0}^{T} \sqrt{1+\dot{x}^{2}} d t$.

(a) Tentukan persamaan Euler serta solusinya.

(b) Tentukan solusi persamaan Euler jika $x(0)=4$, dan $x(10)$ belum ditentukan.

(c) Tentukan solusi persamaan Euler apabila $x(0)=1$, sedangkan $T$ dan $x(T)$ tidak diberikan nilainya, tetapi $x(T)$ melalui garis $g(t)=11-2 t$.

14. Perhatikan masalah meminimumkan ongkos pembangunan jalan yang menghubungkan kota $A(0,1)$ dengan jalan raya yang terletak pada $g(t)=11-2 t$. Asumsikan rata-rata ongkos konstruksi $A C=1$ per kilometer. Tentukan ongkos optimum.

15. (Dynamic Monopoly, dikembangkan oleh Evans (1924)). Monopolis memproduksi dan menjual barang $x(t)$ dengan fungsi permintaan diberikan oleh $x(t)=a p(t)+b+$ $h p(t)$ dan fungsi ongkos $C(x)=\alpha x(t)^{2}+\beta x(t)+\gamma$, dengan $a, b, h, \alpha, \beta, \gamma$ semuanya merupakan konstanta. Monopolis memilih kebijakan harga $p(t)$ yang optimum sehingga memberikan keuntungan $\pi$ yang maksimum untuk jangka waktu perencanaan $T$ tahun, dengan harga awal $p(0)=p_{0}$ dan harga akhir $p(T)=p_{T}$ dan waktu terminal $T$ ditentukan. 


\subsubsection{Soal-Soal Kontrol Optimum}

1. Diberikan masalah kontrol optimum memaksimumkan fungsional objektif $J$ berikut :

$$
\max J(u)=\int_{0}^{1}(x+u) d t
$$

dengan kendala

$$
\dot{x}=1-u^{2}, \quad x(0)=1 .
$$

(a) Tentukan kontrol dan state ekstremal untuk $t \in[0,1]$.

(b) Periksa apakah kontrol dan state yang diperoleh tersebut merupakan kontrol dan state optimum.

(c) Tentukan nilai optimum dari fungsional objektif.

2. Selesaikan masalah kontrol optimum berikut :

(a) $\max \int_{0}^{T} e^{-r t}(1-u) x d t$ dengan kendala $\dot{x}=u x, \quad x(0)=x_{0}>0$, dan kontrol $u \in[0,1]$.

(b) $\max \int_{0}^{T} e^{-r t}(1-u) x d t$ dengan kendala $\dot{x}=u x, \quad x(0)=0, \quad x(T) \geq x_{T}, \quad x_{T}<T / 2$.

(c) $\max \int_{0}^{2}(2 x-3 u) d t$ dengan kendala $\dot{x}=x+u, u \in[0,2], x(0)=5$, dan $x(2)$ bebas.

3. Perhatikan Masalah Kontrol Optimum

$$
\min J[u(t)]=x^{2}(1)+\int_{0}^{1} u^{2}(t) d t
$$

dengan kendala

$$
\dot{x}(t)=x(t)+u(t), \quad x(0)=1,
$$

(a) Tentukan kontrol dan state ekstremal untuk $t \in[0,1]$.

(b) Periksa apakah kontrol dan state yang diperoleh tersebut merupakan kontrol dan state optimum.

(c) Tentukan nilai optimum dari fungsional objektif. 
4. Perhatikan Masalah Kontrol Optimum memaksimumkan fungsional objektif

$$
J[u(t)]=S[x(T), T]+\int_{0}^{T} 1 / 2 u^{2}(t) d t
$$

terhadap kendala

$$
\begin{aligned}
d x_{1}(t) / d t=u(t), & x_{1}(0)=0, \\
d x_{2}(t) / d t=x_{1}(t), & x_{2}(0)=0,
\end{aligned}
$$

dengan peubah kontrol $u(t)$ tanpa batas, dan peubah state $x(t)=\left(x_{1}(t), x_{2}(t)\right)$.

(a) Apabila $T=1, x_{1}(1)=1, x_{2}(1)=2$, dan $S=0$, maka:

i. Tentukan ekstremal dari kontrol dan state untuk masalah di atas;

ii. Periksa apakah kontrol dan state yang diperoleh tersebut memang kontrol dan state optimum;

iii. Hitung nilai optimum fungsional objektif $J$.

(b) Apabila $T=1, x_{1}(1), x_{2}(1)$ bebas, $S[x(1), 1]=1 / 2\left[x_{2}(1)-2\right]^{2}$, maka :

i. Tentukan kontrol dan state ekstremal untuk masalah di atas;

ii. Periksa apakah kontrol dan state yang diperoleh tersebut merupakan kontrol dan state optimum;

iii. Tentukan nilai optimum fungsional objektif $J$.

5. Perhatikan masalah kontrol optimum yang memaksimumkan fungsional objektif :

$$
J[u(t)]=\int_{0}^{4} 3 x d t
$$

dengan kendala $\dot{x}(t)=x(t)+u(t), \quad x(0)=5, \quad x(4)$ bebas dan $u(t) \in[0,2]$.

(a) Tentukan kontrol dan state ekstremal untuk $t \in[0,2]$.

(b) Periksa apakah kontrol dan state yang diperoleh tersebut merupakan kontrol dan state optimum.

(c) Tentukan nilai optimum dari fungsional objektif.

6. Tentukan kontrol optimum untuk masalah berikut : 
(a) Maksimumkan fungsional objektif $J(u)=\int_{0}^{T}-\left(1+u^{2}\right)^{1 / 2} d t$ terhadap kendala $\dot{x}=u$, dan $x(0)=A, x(T)=A$, dengan $A$ dan $T$ diberikan.

(b) Maksimumkan fungsional objektif $J(u)=\int_{0}^{2}(2 x-3 u) d t$ terhadap kendala $\dot{x}=$ $x+u, \quad x(0)=4 \quad x(2)$ bebas, dan $u(t) \in[0,2]$.

7. Tentukan kontrol, state dan kostate yang memaksimumkan fungsional objektif

$$
J(u)=\int_{0}^{2}\left(x-u^{2}\right) d t
$$

dengan kendala $\dot{x}=u, \quad$ dan $\quad x(0)=0, \quad x(2)$ bebas dan kontrol $u(t)$ tidak berkendala.

8. Tentukan kontrol, state dan kostate yang memaksimumkan fungsional objektif

$$
J(u)=\int_{0}^{1}-\frac{1}{2}\left(x^{2}+u^{2}\right) d t
$$

dengan kendala $\dot{x}=u-x$, dan $\quad x(0)=1, \quad x(1)$ bebas dan kontrol $u(t)$ tidak berkendala.

9. Tentukan kontrol, state dan kostate yang memaksimumkan fungsional objektif

$$
J(u)=\int_{0}^{T}-\left(t^{2}+u^{2}\right) d t
$$

dengan kendala $\dot{x}=u, \quad x(0)=4, x(T)=5, \quad T$ bebas.

10. Tentukan kontrol, state dan kostate yang memaksimumkan fungsional objektif

$$
J(u)=\int_{0}^{4} 3 x d t
$$

dengan kendala $\dot{x}=x+u, \quad x(0)=5, \quad x(4) \geq 300$, dan $0 \leq u(t) \leq 2$.

11. Tentukan kontrol, state dan kostate yang memaksimumkan fungsional objektif

$$
J(u)=\int_{0}^{1} x d t
$$

dengan kendala $\dot{x}=x+u, \quad x(0)=0, \quad x(1)$ bebas, dan batasan pada kontrol $-1 \leq u(t) \leq 1$. 
12. Diberikan masalah kontrol optimum untuk meminimumkan fungsional objektif

$$
J(u)=\frac{1}{2}\left[T x_{2}(T)-x_{1}(T)\right]+\frac{1}{2} \int_{0}^{T} u^{2}(t) d t
$$

dengan kendala

$$
\begin{aligned}
& \dot{x}_{1}=x_{2} ; \quad x_{1}(0)=1 ; \quad x_{1}(T) \text { bebas } \\
& \dot{x}_{2}=-u ; \quad x_{2}(0)=2 ; \quad x_{2}(T) \text { bebas }
\end{aligned}
$$

dan (a) kontrol $u$ tidak berbatas, (b) kontrol $|u| \leq 1$.

13. Perhatikan masalah memaksimumkan fungsional objektif

$$
J(u)=\int_{0}^{1}(x+u) d t, \quad \dot{x}=-x+u+t,
$$

$x(0)=1, \quad x(1)$ bebas $u(t) \in[0,1]$.

(a) Misalkan $\left.x^{\star}(t), u^{\star}(t)\right)$ merupakan solusi optimum dari masalah di atas. Tuliskan semua syarat yang harus dipenuhi.

(b) Tunjukan bahwa $p_{0}=1$ dan tentukan solusi tunggal persamaan diferensial dari $p(t)$ yang memenuhi syarat batas.

(c) Tunjukan bahwa kondisi maksimum mengharuskan $u^{\star}(t)$ dipilih dari nilai $u \in$ $[0,1]$, yang memaksimumkan $(1+p(t)) u$. Tentukan $u^{\star}(t)$.

14. Perhatikan masalah memaksimumkan fungsional objektif

$$
J(s(t))=\int_{0}^{T}(1-s(t)) k(t) d t, \quad \dot{k}(t)=s(t) k(t),
$$

$k(0)=k_{0}>0, k(T)$ bebas dan $s(t) \in[0,1], \quad T>1$.

(a) Misalkan $\left(k^{\star}(t), s^{\star}(t)\right)$ solusi dari masalah di atas. Tunjukan bahwa $p_{0}=1$ dan

$$
s^{\star}(t)=\left\{\begin{array}{lll}
1 & \text { jika } & p(t)>1 \\
0 & \text { jika } & p(t)<1
\end{array}\right.
$$

(b) Tunjukkan bahwa $\dot{p}=-1+s^{\star}(t)(1-p(t))$ dengan $p(T)=0$, dan bahwa $\dot{p}<0$ dalam $[0, T]$. Simpulkan bahwa pada suatu selang $\left(t^{\star}, T\right], \quad p(t)<1$ dengan $p\left(t^{\star}\right)=1$. Tentukan $p(t)$ pada $\left(t^{\star}, T\right]$ dan tunjukkan bahwa $t^{\star}=T-1$. 
(c) Simpulkan bahwa $s^{\star}(t)=1$ pada $[0, T-1]$, dan $s^{\star}(t)=0$ pada $(T-1, T]$.

(d) Ganti syarat $k(T)$ bebas dengan $k(T) \geq k_{T}$ dengan $k_{0}<K_{T}<k_{0} e^{T}$, dan tentukan kandidat tunggal untuk optimum.

15. Tentukan fungsi kontrol yang memberikan solusi untuk masalah

$$
\max \int_{0}^{2}\left(2 x-3 u-u^{2}\right) d t
$$

dengan kendala $\dot{x}=x+u, \quad 0 \leq u \leq 2, \quad x(0)=5, \quad x(2)$ bebas.

16. Jumlah populasi ikan dalam suatu danau, apabila tidak diganggu oleh manusia, tumbuh pada tingkat

$$
\dot{N}(t)=a N(t)-b N^{2}(t)
$$

Ikan dapat ditangkap dari danau dan dikonsumsi pada tingkat $c(t)$, menghasilkan utilitas $u(c(t))$ untuk konsumsi masyarakat dan mengakibatkan pengurangan tingkat pertumbuhan menjadi

$$
\dot{N}(t)=a N(t)-b N^{2}(t)-c(t)
$$

Asumsikan utilitas masyarakat di waktu depan memperoleh diskon pada tingkat $r$. Berikan karakteristik rencana konsumsi ikan untuk memaksimumkan nilai sekarang dari tingkat utilitas yang didiskon. Asumsikan bahwa $N(0)=a / b$, dan $\dot{u}>0, \ddot{u}<0$.

17. Pendapatan individu proporsional terhadap produk human kapital $K(t)$ dan waktu yang digunakan, $1-s(t)$. Human kapital menyusut secara konstan dengan proporsi $b$ dan sebaliknya bertambah dengan meningkatnya investasi, berupa fungsi konkaf(cembung) dari kapital dan $s(t)$ merupakan proporsi waktu yang didedikasikan untuk pendidikan. Diskusikan program pendidikan-bekerja untuk memaksimumkan pendapatan yang didiskon untuk jangka sisa waktu hidup $T$

$$
\max \int_{0}^{T} e^{-r t}(1-s(t)) K(t) d t
$$

dengan kendala

$$
\dot{K}=A(s K)^{a}-b K, \quad K(0)=K_{0}>0, \quad 0 \leq s \leq 1,
$$

dengan ketentuan $A>0, \quad 0<a<1, \quad b \geq 0$. 
18. Investasi suatu perusahaan haruslah self-financed, yaitu harus dibiayai dari pendapatan (revenues) yang sedang berjalan. Misal $R(K)$ menyatakan revenue bersih yang diperoleh dari modal $K$. Misalkan $C(I)$ menyatakan biaya melakukan investasi dengan tingkat $I$. Asumsikan $\dot{R}>0, \quad \ddot{R}<0, \quad \dot{C}>0, \quad \ddot{C}>0$. Diskusikan solusi optimum untuk masalah

$$
\max \int_{0}^{\infty} e^{-r t}[R(K)-C(I)] d t
$$

dengan kendala

$$
\dot{K}=I-b K, \quad K(0)=K_{0}, \quad 0 \leq I \leq R(K)
$$




\section{Kumpulan Soal}

\section{Kumpulan $\mathbf{1}^{1}$}

1. Tentukan ekstremum untuk masalah berikut :

(a) $\int_{0}^{1}\left[\dot{x}^{2}+10 t x\right] d t$, dengan kendala $x(0)=1$, dan $x(1)=2$.

(b) $\int_{0}^{1}\left(\ddot{x}^{2}+\dot{x}+a t^{2}\right) d t$, dengan $x(0)=0, \dot{x}(0)=1, x(1)=1$, dan $\dot{x}(1)=1$.

(c) $\int_{1}^{2}\left[x+t \dot{x}-\dot{x}^{2}\right] d t$, dengan kendala $x(1)=3$, dan $x(2)=4$.

2. Maksimumkan $\int_{0}^{5} \dot{x}^{2} d t$, terhadap kendala $x(0)=1, x(5)=11$ dan $\int_{0}^{5}(1+x) d t=5$.

3. Perhatikan masalah meminimumkan fungsional objektif $J[x(t)]$ yang didefinisikan oleh

$$
J[x(t)]=\int_{0}^{T}\left[t \dot{x}(t)+\dot{x}^{2}(t)\right] d t .
$$

(a) Tentukan solusi yang memenuhi kendala $x(0)=5, \quad x(T)$ bebas dan $T=2$.

(b) Tentukan ekstremum apabila $x(0)=0, \quad x(T)=T+1,(T>1)$.

(c) Tentukan solusi yang memenuhi kendala $x(0)=1, \quad x(1) \geq 1$.

4. Tentukan ekstremum untuk masalah pertumbuhan yang memaksimumkan fungsional objektif

$$
J(K)=\int_{0}^{T} \frac{1}{\gamma}(b K-\dot{K})^{\gamma} e^{-\rho t} d t, \quad K(0)=K_{0}, \quad K(T)=K_{T}, 0<\gamma<1,
$$

dan waktu terminal $T$ diberikan.

\footnotetext{
${ }^{1}$ Ujian Tengah Semester, MAT 364 : Kontrol Optimum, Jum'at : 21 Maret 2003
} 
5. Tentukan ekstremum yang memberikan minimum fungsional objektif

$$
J(x)=\int_{0}^{\pi / 2}\left(\dot{x}_{1}^{2}+\dot{x}_{2}^{2}+2 x_{1} x_{2}\right) d t, \quad x_{1}(0)=0=x_{2}(0),
$$

dan $\quad x_{1}(\pi / 2)=1, \quad x_{2}(\pi / 2) \quad$ bebas. 


\section{Kumpulan $2^{2}$}

1. Tentukan ekstremum untuk masalah berikut :

(a) $\int_{0}^{1}\left[\dot{x}^{2}+10 t x\right] d t$, dengan kendala $x(0)=1$, dan $x(1)=2$.

(b) $\int_{0}^{1}\left(\ddot{x}^{2}+\dot{x}+a t^{2}\right) d t$, dengan $x(0)=0, \dot{x}(0)=1, x(1)=1$, dan $\dot{x}(1)=1$.

(c) $\int_{1}^{2}\left[x+t \dot{x}-\dot{x}^{2}\right] d t$, dengan kendala $x(1)=3$, dan $x(2)=4$.

2. Maksimumkan $\int_{0}^{5} \dot{x}^{2} d t$, terhadap kendala $x(0)=1, \quad x(5)=11$ dan $\int_{0}^{5}(1+x) d t=5$.

3. Perhatikan masalah meminimumkan fungsional objektif $J[x(t)]$ yang didefinisikan oleh

$$
J[x(t)]=\int_{0}^{T}\left[t \dot{x}(t)+\dot{x}^{2}(t)\right] d t .
$$

(a) Tentukan solusi yang memenuhi kendala $x(0)=5, \quad x(T)$ bebas dan $T=2$.

(b) Tentukan ekstremum apabila $x(0)=0, \quad x(T)=T+1,(T>1)$.

(c) Tentukan solusi yang memenuhi kendala $x(0)=1, \quad x(1) \geq 1$.

4. Tentukan ekstremum untuk masalah pertumbuhan yang memaksimumkan fungsional objektif

$$
J(K)=\int_{0}^{T} \frac{1}{\gamma}(b K-\dot{K})^{\gamma} e^{-\rho t} d t, \quad K(0)=K_{0}, \quad K(T)=K_{T}, 0<\gamma<1
$$

dan waktu terminal $T$ diberikan.

5. Tentukan ekstremum yang memberikan minimum fungsional objektif

$$
J(x)=\int_{0}^{\pi / 2}\left(\dot{x}_{1}^{2}+\dot{x}_{2}^{2}+2 x_{1} x_{2}\right) d t, \quad x_{1}(0)=0=x_{2}(0),
$$

dan $\quad x_{1}(\pi / 2)=1, \quad x_{2}(\pi / 2) \quad$ bebas.

\footnotetext{
${ }^{2}$ Ujian Tengah Semester, MAT 364 : Kontrol Optimum,Jum'at : April 2005
} 


\section{Kumpulan $3^{3}$}

1. Tentukan kontrol dan state optimum untuk masalah berikut:

(a) Maksimumkan fungsional objektif

$$
J(u(t))=\int_{0}^{1}\left(x-u^{2}\right) d t
$$

terhadap kendala

$$
\dot{x}(t)=u(t) ; \quad x(0)=0, \quad x(1) \quad \text { bebas dan kontrol tidak berbatas. }
$$

(b) Minimumkan fungsional objektif

$$
J(u(t))=\frac{1}{2} x(1)^{2}+\frac{1}{2} \int_{0}^{1} u^{2} d t
$$

terhadap kendala $\dot{x}=-u(t), \quad x(0)=1, \quad x(1) \quad$ bebas dan kontrol tidak berbatas

2. Diberikan sistem dinamis

$$
\begin{array}{ll}
\dot{x}_{1}(t)=x_{2}(t), & x_{1}(0)=0 \\
\dot{x}_{2}(t)=u(t), & x_{2}(0)=0,
\end{array}
$$

dengan peubah state dan peubah kontrol tidak berbatas. Tentukan kontrol optimum yang memaksimumkan fungsional objektif

$$
J(u(t))=S(x(T))-\int_{0}^{T} \frac{1}{2} u^{2}(t) d t
$$

apabila :

(a) $x_{1}(1)=2 ; x_{2}(1)=3 ; T=1 ; \quad S(x(T))=0$.

(b) $T=1, x_{1}(1), x_{2}(1)$ tidak diberikan, dan $S(x(T))=\frac{1}{2}\left[T x_{2}(T)-x_{1}(T)\right]$.

(c) $x_{1}(T)=2 ; x_{2}(T)=3 ; \quad T$ bebas; $S(x(T))=0$.

3. Tentukan kontrol optimum untuk masalah meminimumkan fungsional objektif

$$
J(u(t))=\int_{0}^{T}\left[a x(t)+b u(t)+c u^{2}(t)\right] d t
$$

dengan kendala $\dot{x}(t)=u(t), \quad x(0)=x_{0}$ tetap, $T$ tetap, $x(T)$ bebas $c>0$.

\footnotetext{
${ }^{3}$ UJIAN AKHIR SEMESTER, MAT 364 : KONTROL OPTIMUM, Jumat, 23 Mei 2003.
} 
4. Perhatikan masalah kontrol optimum yang memaksimumkan fungsional objektif :

$$
J[u(t)]=\int_{0}^{4} 3 x d t
$$

dengan kendala $\dot{x}(t)=x(t)+u(t), \quad x(0)=5, \quad x(4)$ bebas dan $u(t) \in[0,2]$.

(a) Tentukan kontrol dan state ekstremal untuk $t \in[0,4]$.

(b) Periksa apakah kontrol dan state yang diperoleh tersebut merupakan kontrol dan state optimum.

(c) Tentukan nilai optimum dari fungsional objektif.

5. Perhatikan masalah memaksimumkan fungsional objektif

$$
J(s(t))=\int_{0}^{T}(1-u(t)) x(t) d t, \quad \dot{x}(t)=u(t) x(t),
$$

$x(0)=x_{0}>0, x(T)$ bebas dan $u(t) \in[0,1], \quad T>1$.

(a) Misalkan $\left(x^{\star}(t), u^{\star}(t)\right)$ solusi dari masalah di atas. Tunjukan bahwa

$$
u^{\star}(t)=\left\{\begin{array}{lll}
1 & \text { jika } & p(t)>1 \\
0 & \text { jika } & p(t)<1
\end{array}\right.
$$

(b) Tunjukkan bahwa $\dot{p}=-1+u^{\star}(t)(1-p(t))$ dengan $p(T)=0$, dan bahwa $\dot{p}<0$ dalam $[0, T]$. Simpulkan bahwa pada suatu selang $\left(t^{\star}, T\right], \quad p(t)<1$ dengan $p\left(t^{\star}\right)=1$. Tentukan $p(t)$ pada $\left(t^{\star}, T\right]$ dan tunjukkan bahwa $t^{\star}=T-1$.

(c) Simpulkan bahwa $u^{\star}(t)=1$ pada $[0, T-1]$, dan $u^{\star}(t)=0$ pada $(T-1, T]$. 


\section{Kumpulan $4 .^{4}$}

1. Perhatikan Masalah Kontrol Optimum

$$
\min J[u(t)]=x^{2}(1)+\int_{0}^{1} u^{2}(t) d t
$$

dengan kendala $\dot{x}(t)=x(t)+u(t), \quad x(0)=1$.

(a) Tentukan kontrol dan state ekstremum untuk $t \in[0,1]$.

(b) Periksa apakah kontrol dan state yang diperoleh tersebut merupakan kontrol dan state yang optimum, yaitu meminimumkan fungsional $J$.

(c) Tentukan nilai optimum dari fungsional objektif.

2. Perhatikan Masalah Kontrol Optimum

$$
\max J(u)=\int_{0}^{1}-\frac{1}{2}\left(x^{2}+u^{2}\right) d t
$$

dengan kendala $\dot{x}=u-x$, dan $\quad x(0)=1, \quad x(1)$ bebas, dan kontrol $u(t)$ tanpa batas.

(a) Tentukan kontrol dan state ekstremum untuk $t \in[0,1]$.

(b) Periksa apakah kontrol dan state yang diperoleh tersebut merupakan kontrol dan state yang optimum, yaitu memaksimumkan fungsional $J$.

(c) Tentukan nilai optimum dari fungsional objektif.

3. Selesaikan masalah kontrol optimum yang memaksimumkan fungsional objektif

$$
J(u)=\int_{0}^{T}-\left(t^{2}+u^{2}\right) d t
$$

dengan kendala $\dot{x}=u, \quad x(0)=4, x(T)=5, \quad T$ bebas.

4. Tentukan kontrol optimum yang memaksimumkan fungsional objektif

$$
\max J(u)=\int_{0}^{2}(2 x-3 u) d t
$$

dengan kendala $\dot{x}=x+u, \quad x(0)=5, \quad$ dan $\quad x(2)$ bebas dan kontrol $u \in[0,2]$.

\footnotetext{
${ }^{4}$ Ujian Akhir Semester, MAT 364 : Kontrol Optimum, Rabu, 15 Juni 2005
} 
5. Tentukan kontrol, state dan kostate yang memaksimumkan fungsional objektif

$$
J(u)=\int_{0}^{4} 3 x d t
$$

dengan kendala $\dot{x}=x+u, \quad x(0)=5, \quad x(4) \geq 300$, dan $0 \leq u(t) \leq 2$. 


\section{Historiana}

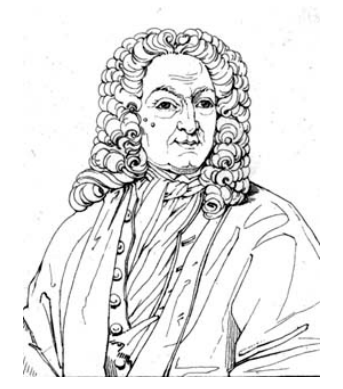

Gambar 3.1: Johann Bernoulli (1667 - 1748), matematikawan dari Swiss yang mempelajari pantulan dan refraksi cahaya, lintasan ortogonal dari keluarga kurva, dan brachistochrone yang merupakan cikal bakal kalkulus variasi. (Sumber: Mac Tutor History of Mathematics Archive)

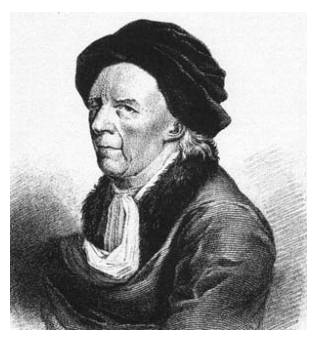

Gambar 3.2: Leonhard Euler (1707-1783), Matematikawan dari Swiss yang memberikan syarat perlu peminimum dari fungsional Kalkulus Variasi. Euler mempelajari brachistochrone dari Johann Bernoulli. Dan menamai disiplin baru sebagai kalkulus variasi Syarat EulerLagrange. (Sumber: Mac Tutor History of Mathematics Archive) 


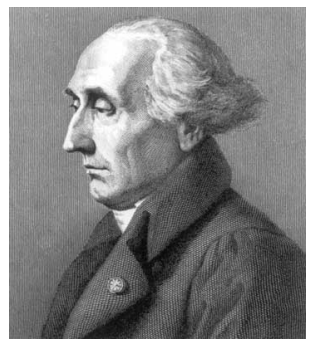

Gambar 3.3: Joseph-Louis Lagrange (1736-1813), matematikawan Perancis yang membahas formulasi kalkulus variasi dalam bidang fisika. Dari korespondensinya dengan Euler, melahirkan kondisi minimum dari sebuah fungsional dalam kalkulus variasi. Kini dikenal dengan Syarat Euler-Lagrange. (Sumber: Mac Tutor History of Mathematics Archive)

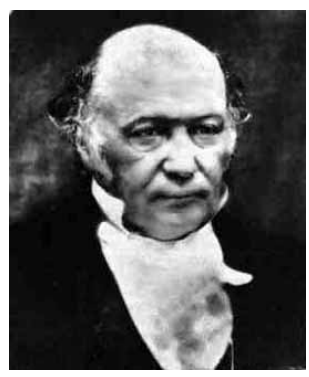

Gambar 3.4: Sir William Rowan Hamilton (1805-1865) Matematikawan dari Irlandia, yang memperkenalkan fungsional yang dikenal dengan Hamiltonian. Konsep ini lahir dari kajian Hamilton dalam bidang mekanika menggunakan Kalkulus Variasi.(Sumber: Mac Tutor History of Mathematics Archive) 


\section{Bab 4}

\section{Penyelesaian Masalah Kontrol}

\section{Optimum Sebagai Masalah Syarat}

\section{Batas Persamaan Diferensial Biasa}

\section{Dalam SCILAB}

Diuraikan penggunaan rutin bvode dalam lingkungan SCILAB untuk menyelesaikan masalah syarat batas (MSB) sistem persamaan diferensial biasa untuk menyelesaikan masalah kontrol optimum (MKO). Bagian ini bersifat pedagogis dengan tujuan agar pengguna dapat mempergunakan solver bvode yang tersedia di lingkungan SCILAB untuk memecahkan masalah syarat batas secara numerik dari $\mathrm{MKO}$, setelah membaca uraian penggunaan rutin pemecahan masalah syarat batas.

Persamaan Differensial Biasa (PDB) sering muncul sebagai model banyak permasalahan dalam berbagai bidang ilmu pengetahuan. Pencarian solusi PDB diperlukan untuk memperoleh interpretasi dari model permasalahan semula. Mendapatkan solusi analitik dari PDB, tidak selamanya mudah diperoleh.

Ada kalanya solusi yang sangat spesifik ingin didapatkan dari suatu sistem PDB dengan cara menentukan nilai-nilai awal pada lebih dari satu titik $x$. Permasalahan seperti ini 
dikenal dengan nama Masalah Syarat Batas (MSB), yang dinyatakan oleh :

$$
\begin{aligned}
y^{n} & =f\left(x, y, y^{\prime}, y^{\prime \prime}, \ldots, y^{n-1}\right), \\
y\left(a_{1}\right) & =b_{1}, \\
y\left(a_{2}\right) & =b_{2} .
\end{aligned}
$$

Dalam lingkungan Scilab, tersedia sebuah rutin untuk menyelesaikan MSB berdasarkan metode kolokasi. Rutin numerik ini bernama bvode. Metode kolokasi ini juga digunakan dalam lingkungan MATLAB untuk rutin bvp4c.

Bagian ini dapat dijadikan sebuah tutorial yang memberikan penuntun bagaimana memformulasikan masalah (menyusun perintah), mendapatkan solusi numerik, dan menggambarkan solusi secara grafis dari MSB dengan menggunakan rutin bvode. Bagian ini juga merupakan studi pendahuluan numerik atas ketersediaan lingkungan pemecah masalah numerik (numerical problem solving environment\{PSE\})yang bersifat open-source dan merdeka sebagai alternatif dari PSE komersial populer MATLAB yang menawarkan rutin bvp4c untuk memecahkan MSB.

Salah satu tujuan bagian ini bersifat pedagogis yang menguraikan secara sederhana bagaimana mendapatkan solusi numerik MSB sebuah PDB. Dengan demikian, seseorang dapat mempergunakan bvode untuk menyelesaikan MSB yang dihadapinya tanpa kesulitan, disamping itu, contoh yang diberikan muncul dari masalah perkuliahan lain yang biasanya ditemui di tahun ketiga atau keempat di perguruan tinggi. Selain itu, tulisan ini bertujuan untuk menyediakan dokumentasi tertulis berbahasa Indonesia.

Bab ini disusun secara berturutan sebagai berikut. Pertama diuraikan secara singkat formulasi MKO sebagai MSB sebagaimana dibahas dalam Bab 3. Kemudian diikuti uraian dari yang mendeskripsikan bvode, yang diikuti dengan sebuah penyelesaian MSB. Kemudian diperlihatkan penggunaannya untuk menyelesaikan MKO sebagai MSB dalam lingkungan Scilab mempergunakan bvode, serta sejumlah contoh tambahan formulasi MKO sebagai MSB. Diakhiri oleh kesimpulan serta kemungkinan pekerjaan lanjutan. 


\subsection{Formulasi Masalah Kontrol Optimum Sebagai Ma- salah Syarat Batas.}

Dalam masalah kontrol optimum, formulasinya adalah kita ingin menentukan input $u(t)$ yang meminimumkan fungsional skalar berbentuk:

$$
J=\phi\left(x\left(t_{f}\right)\right)+\int_{0}^{t_{f}} L(x, u, t) d t
$$

jika diberikan kendala dinamika tak-linear berbentuk:

$$
\frac{d x}{d t}=f(x, u, t), x(t=0)=x_{0}
$$

Melalui kalkulus variasi (lihat Bab Kontrol Optimum : Pendekatan Kalkulus Variasi), solusi dari masalah kontrol optimum persamaan (4.2) dengan kendala (4.3) dapat diperoleh melalui rumusan MSB berikut

$$
\begin{aligned}
& \frac{d x}{d t}=f(x, u, t), \quad x(t=0)=x_{0} \\
& \frac{d \lambda}{d t}=-\frac{\partial H}{\partial x}, \quad \lambda\left(t_{f}\right)=\left.\frac{\partial \phi}{\partial x}\right|_{t_{f}}
\end{aligned}
$$

dengan $\lambda$ adalah peubah state adjoint dan Hamiltonian $H$ diberikan oleh

$$
H(x, \lambda, u, t)=L(x, u, t)+\lambda f(x, u, t)
$$

Serta input kontrol yang merupakan solusi dari:

$$
\frac{\partial \lambda}{\partial u}+\lambda^{T} \frac{\partial f}{\partial u}=0
$$

Persamaan (4.7) tidak trivial untuk menyelesaikannya, karena harus menyelesaikan MSB (4.4) dan (4.5) dengan kendala yang bersifat aljabar. 


\subsection{Deskripsi bvode Untuk Menyelesaikan Masalah Sya- rat Batas Dalam SCILAB}

Rutin bvode yang tersedia dalam PSE Scilab, merupakan perangkat simulasi untuk menyelesaikan MSB. Rutin bvode pada dasarnya mempergunakan pustaka COLNEW, yang merupakan perbaikan dari rutin program COLSYS ([1, 2]) yang ditulis mempergunakan FORTRAN dan berlandaskan metode kolokasi. Tidak seperti solver PDB pada umumnya, bvode tidak mengharuskan pengguna mengubah persamaan differensial orde tinggi menjadi sistem persamaan differensial orde satu. Selain itu, dimungkinkan diberikannya sejumlah syarat di sejumlah titik $\zeta_{j}$.

Bentuk MSB yang diasumsikan oleh bvode ialah :

$$
\begin{aligned}
& \frac{d^{m_{i}} y_{i}}{d x^{m_{i}}}=f_{i}\left(x, y(x), \frac{d y}{d x}, \cdots, \frac{d^{m_{i}-1} y}{d x^{m_{i}-1}}\right), \\
& 1 \leq i \leq n_{c}, \\
& g_{j}\left(\zeta_{j}, y\left(\zeta_{j}\right), \cdots, \frac{d^{m_{*}} y}{d x^{m_{*}}}\left(\zeta_{j}\right)\right)=0, j=1, \cdots, m_{*} .
\end{aligned}
$$

dengan $\zeta_{j}$ merupakan posisi dimana syarat batas berlaju dan $a_{L} \leq \zeta_{j} \leq a_{R}$. Agar notasi tidak menyulitkan, tuliskan

$$
\begin{aligned}
m_{*} & =m_{1}+m_{2}+\cdots+m_{n_{c}} \\
z(y) & =\left[y, \frac{d y}{d x}, \cdots, \frac{d^{m_{*}} y}{d x^{m_{*}}} .\right]
\end{aligned}
$$

Maka bentuk umum MSB yang diasumsikan oleh bvode ialah

$$
\begin{aligned}
\frac{d^{m_{i}} y_{i}}{d x^{m_{i}}} & =f_{i}(x, z(y(x))), 1 \leq i \leq n_{c}, a_{L} \leq \zeta_{j} \leq a_{R} \\
g_{j}\left(\zeta_{j}, z\left(y\left(\zeta_{j}\right)\right)\right) & =0, j=1, \cdots, m_{*} .
\end{aligned}
$$

Rutin bvode memiliki kemampuan untuk menyelesaikan MSB yang linear maupun nonlinear. Karena itu rutin ini mengharuskan pengguna menyusun sendiri matriks Jacobian 
dari PDB yang hendak diselesaikan, maka untuk beberapa masalah, tingkat kerumitan yang paling besar akan terasa pada penyusunan matriks Jacobian ini.

Seperti halnya fungsi lain pada SCILAB, rutin bvode memiliki tata cara pemanggilan sebagai berikut ini

$$
\begin{array}{r}
{[\mathrm{z}]=\text { bvode (points, ncomp, } \mathrm{m}, \text { aleft, aright, zeta, ipar,... }} \\
\text { ltol, tol, fixpnt, fsub, dfsub, gsub, dgsub, guess); }
\end{array}
$$

dengan z merupakan vektor baris yang berisi solusi numerik dari MSB yang ingin diselesaikan. Komponen z (i, : ) merepresentasikan turunan ke-(i-1) dari solusi pada selang domain (contoh: $\mathbf{z}(1,:)$ menyatakan $y, z(2,:)$ menyatakan $y^{\prime}$, dan seterusnya hingga $z(m *,:)$ menyatakan $\left.y^{\left(m^{*}-1\right)}\right)$.

Lima argumen terakhir yang diperlukan bvode berbentuk fungsi yang harus didefinisikan sendiri oleh pengguna, sedangkan argumen lainnya merupakan informasi yang diperlukan bvode untuk dapat mencari solusi numerik berkaitan dengan MSB yang ingin diselesaikan. Berikut adalah tabel yang menjelaskan kegunaan masing-masing parameter yang digunakan oleh bvode.

z : Solusi dari PDB yang dievaluasi atas mesh yang diberikan oleh points.

points : Array yang menyimpan titik di selang domain dimana MSB akan dicari solusinya.

ncomp : Jumlah persamaan differensial. Syaratnya haruslah ncomp $\leq 20$.

$m$ : Vektor dengan panjang ncomp, yang isinya $m(j)$ berupa orde dari persamaan differensial ke- $j$. Orde dari persamaan diferensial harus disyaratkan $m(i) \leq 4$.

aleft : Ujung kiri dari selang domain dimana $y$ didefinisikan.

aright: Ujung kanan dari selang domain dimana $y$ didefinisikan.

zeta: Isi zeta $(j)$ berisi titik syarat (batas) tambahan ke- $j$. Isi harus diurutkan sehingga $\operatorname{zeta}(j) \leq \operatorname{zeta}(j+1)$. Semua titik syarat tambahan (batas) harus pada titik mesh di semua mesh yang digunakan. Khususnya, titik tersebut harus merupakan bagian dari mesh 
awal. Perhatikan pula uraian lebih rinci mengenai parameter ipar(11) dan fixpnt di bawah ini.

ipar : Array berentri bilangan bulat dengan ukuran sedikitnya 11. Daftar parameter dari ipar akan diuraikan terkemudian.

ltol: Array dengan panjang yang ditentukan ipar(4). Itol $(j)=1$ menentukan toleransi ke- $j$ di tol mengendalikan error di komponen ke- $l$ dari z(u). Juga dipersyaratkan bahwa $1 \leq \operatorname{ltol}(1)<\operatorname{ltol}(2)<\cdots<\operatorname{ltol}($ ntol) $\leq$ mstar.

tol : Array dengan panjang yang ditentukan ipar(4). tol(j) menyatakan toleransi pada komponen ke ltol $(j)$ dari solusi $z(u)$.

fixpnt : Titik selain aleft dan aright yang akan dimasukkan ke dalam mesh.

fsub : Fungsi yang mendefinisikan PD yang ingin dicari solusi numeriknya.

dfsub : Matriks Jacobian dari fsub.

gsub : Fungsi yang mendefinisikan persamaan syarat batas untuk MSB yang bersangkutan.

dgsub : Matriks Jacobian dari gsub.

guess : Tebakan awal bagi solusi (jika tersedia).

Dari kelimabelas parameter di atas, argumen ipar adalah argumen yang paling panjang. Argumen ini memiliki 11 komponen yang secara keseluruhan memberi kesempatan pengguna untuk mengatur setting pada metode numerik yang digunakan bvode. Sebagian komponen dari parameter ipar berhubungan langsung dengan beberapa argumen bvode pada daftar parameter di atas. Sebagian besar dari komponen-komponen tersebut memiliki nilai default nol. Karena jumlah komponennya yang terbilang cukup banyak, ada baiknya jika dibuat variabel berdimensi $1 \times 11$ yang berisi nilai nol (default) sebelum mengisi komponen-komponen yang tidak bernilai default, yaitu

ipar $=\operatorname{zeros}(1,11)$ 
Isikan masing-masing komponen parameter ipar berdasarkan keterangan yang didaftarkan di bawah ini:

ipar(1) : = 0 jika MSB linear dan $=1$ jika MSB non-linear.

ipar(2) : Banyaknya titik kolokasi per subinterval $(=\mathrm{k})$ dimana orde maksimum PD $\leq \mathrm{k} \leq 7$. Jika ipar $(2)=0$ maka secara default $\mathrm{k}=\max (\max \mathrm{m}(\mathrm{i})+1,5-\max \mathrm{m}(\mathrm{i}))$.

ipar(3): Banyaknya subinterval pada mesh awal $(=\mathrm{n})$. Jika ipar(3) $=0$ maka secara default $\mathrm{n}=5$.

ipar(4): Banyaknya komponen solusi beserta turunannya yang diberi toleransi ( = ntol ), dengan aturan $0 \leq$ ntol $\leq m^{*}$.

ipar(5): Nilai yang menentukan banyaknya subinterval maksimum (nmax) pada selang domain. Pilihlah ipar(5) berdasarkan rumus berikut: ipar(5) $\geq$ nmax $\cdot$ nsizef dimana nsizef $=4+3 * \mathrm{~m} *+(5+\mathrm{kd}) * \mathrm{kdm}+(2 * \mathrm{~m} *-\mathrm{nrec}) * 2 * \mathrm{~m} *$ dengan $\mathrm{nrec}=$ banyaknya syarat batas pada ujung kanan selang domain ipar(5) diperuntukkan evaluasi pada titik-titik selang real.

ipar(6) : Nilai yang menentukan banyaknya subinterval maksimum (nmax) pada selang domain. Pilihlah ipar(6) berdasarkan rumus berikut: ipar(6) $\geq$ nmax $\cdot$ nsizei dimana $\mathrm{nsizei}=3+\mathrm{kdm}$ dengan $\mathrm{kdm}=\mathrm{kd}+\mathrm{m}^{*} ; \mathrm{kd}=\mathrm{k} \cdot \mathrm{ncomp} ;$ ipar(6) diperuntukkan evaluasi pada titik-titik integer.

ipar(7): Kontrol output berikan nilai berikut: $=-1$ untuk printout diagnostik penuh $=0$ untuk printout sederhana.. = 1 tanpa printout.

ipar(8): =0 untuk mesh awal seragam.

ipar(9) : = 0 jika tidak tersedia tebakan awal bagi solusi. = 1 jika tebakan awal tersedia pada fungsi guess.

ipar(10) : = 0 jika masalah bersifat reguler. = 1 jika iterasi nonlinear tidak bergantung pada kekonvergenan dari iterasi sebelumnya (hanya digunakan jika ipar $(1)=1$ ). = 2 jika proses ingin dihentika setelah (a) terjadi dua kali non-konvergen berturut-turut, atau (b) pendekatan galat didapatkan untuk pertama kalinya. 
ipar(11): Banyaknya titik selain ujung-ujung selang domain yang akan dimasukkan ke dalam mesh (dimensi dari argumen fixpnt).

\section{Contoh penyelesaian MSB dengan SCILAB.}

Pada bagian ini akan dibahas contoh bagaimana menyelesaikan MSB dengan mempergunakan bvode.

Pada bagian ini juga akan ditunjukkan bagaimana cara menggambar masing-masing komponen solusi numerik yang didapat dari bvode. Program lengkap yang disimpan dalam bentuk file .sci dapat dilihat pada lampiran yang disertakan bersama tutorial ini.

Berikut ini diberikan ilustrasi bagaimana mendapatkan solusi numerik dari MSB yang melibatkan parameter yang tidak diketahui. Permasalahannya adalah menghitung nilai eigen dari persamaan Mathieu berikut ini,

$$
y^{\prime \prime}+(\lambda-2 q \cos (2 x)) y=0,
$$

pada selang $[0, \pi]$, dengan syarat batas $y^{\prime}(0)=0, y^{\prime}(\pi)=0$ untuk $q=5$. Solusi dinormalisasi dengan cara menetapkan solusi memenuhi $y(0)=1$. Permasalahan sesunguhnya adalah mencari nilai $\lambda$ yang memenuhi syarat batas $y^{\prime}(\pi)=0$. Nilai tebakan awal bagi $\lambda$ menjadi keharusan dalam menyelesaikan masalah ini.

$\left.\operatorname{deff}\left({ }^{\prime} f=f \operatorname{sub}(x, z)\right)^{\prime}, ' f=[-(1 \operatorname{ambda}-2 * q * \cos (2 * x)) * z(1)]^{\prime}\right)$

$\operatorname{deff}\left({ }^{\prime} d f=\operatorname{dfsub}(x, z), \quad, \quad d f=[-(\operatorname{lambda}-2 * q * \cos (2 * x)), 0] '\right)$

Persamaan syarat batas untuk contoh ini didefinisikan sebagai berikut, dengan terlebih dahulu membuat ruas kanannya menjadi nol:

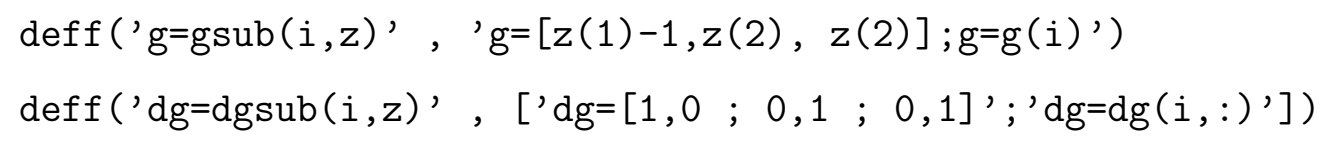


Karena tebakan awal bagi solusi $y$ tidak tersedia maka fungsi guess didefinisikan seperti di bawah ini.

$\operatorname{deff}\left({ }^{\prime}[z, \operatorname{mpar}]=\operatorname{guess}(\mathrm{x}){ }^{\prime},{ }^{\prime}, '\right)$

Jika tebakan awal bagi nilai eigen dipilih $\lambda=15$, maka untuk menyelesaikan MSB (4.12) sekaligus mendapatkan nilai pendekatan untuk $\lambda$ dapat dilakukan dengan menambahkan loop seperti pada listing berikut,

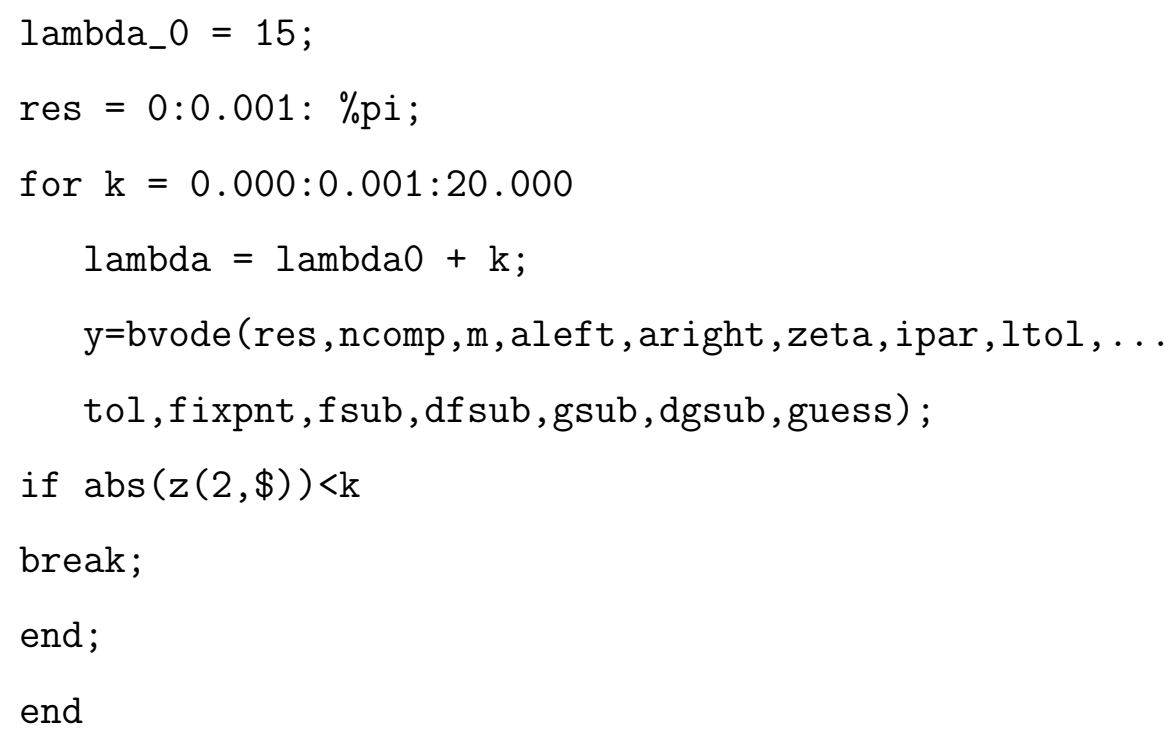

Untuk melihat gambar grafik solusi numerik untuk $y(x)$ yang dihasilkan bvode dan untuk mengetahui nilai $\lambda$ yang didapat dari loop di atas, perintah berikut dengan cepat akan menampilkan keduanya:

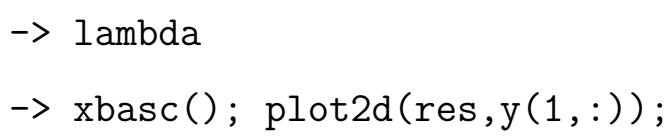

Dari hasil perhitungan yang dilakukan oleh bvode beserta loop di atas, didapat nilai pendekatan $\lambda=17.096$ dan gambar grafik solusi $y(x)$ seperti yang terlihat pada gambar 1. Perhitungan di atas mempergunakan mesh dengan lebar kisi $\Delta x=0.001$ yang seragam untuk selang $[0, \pi]$. 


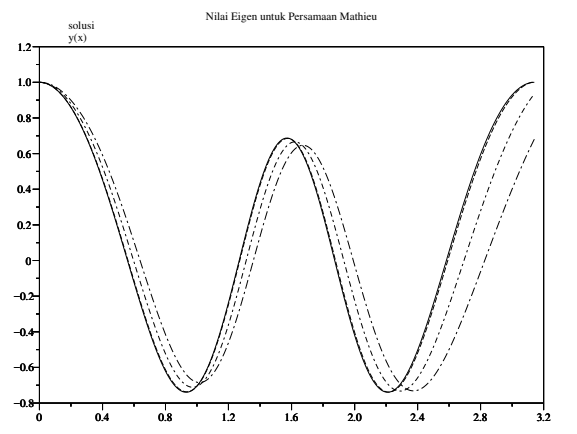

Gambar 4.1: Fungsi eigen dari persamaan Mathieu terkait dengan nilai eigen yang digunakan dalam contoh.

\section{Penyelesaian MSB dari MKO}

Berikut ini diberikan sebuah MSB yang berasal dari Masalah Kontrol Optimal. Biasanya, syarat cukup untuk kontrol optimal berupa MSB, yang biasanya lebih mudah menyelesaikannya untuk banyak masalah sederhana.

Perhatikan masalah sistem terkontrol

$$
y^{\prime}=y^{2}+v
$$

dan kita inginkan kontrol $v$ mengendalikan lintasan dari 2 pada saat $t=0$ ke -1 pada saat $t=10$. Dengan demikian, kita inginkan $v$ meminimumkan fungsional ongkos kuadratik berikut

$$
J(y, v)=\int_{0}^{10}\left(y^{2}+10 v^{2}\right) d t .
$$

Fungsional ongkos ini menyebabkan variabel keadaan $y$ dan variabel kontrol $v$ terkendala, sehingga menyebabkan variabel keadaan dan kontrol menjadi kecil.

Syarat cukup dapat diperoleh dengan mendefinisikan fungsi Hamiltonian

$$
H=\left(y^{2}+10 v^{2}\right)+\lambda\left(y^{2}+v\right)
$$


dan kita tuliskan masalah syarat batas persamaan diferensial aljabar

$$
\left.\begin{array}{rl}
y^{\prime} & =\frac{\partial H}{\partial \lambda}, \\
-\lambda^{\prime} & =\frac{\partial H}{\partial y}, \\
0 & =\frac{\partial H}{\partial v}, \\
y(0) & =2, \quad y(10)=1,
\end{array}\right\}
$$

yang berupa

$$
\left.\begin{array}{rl}
y^{\prime} & =y^{2}+v, \\
\lambda^{\prime} & =-2 y-2 \lambda y, \\
0 & =20 v+\lambda, \\
y(0) & =2, \quad y(10)=1,
\end{array}\right\}
$$

bila $v$ dieliminasi, akan diperoleh MSB

$$
\left.\begin{array}{rl}
y^{\prime} & =y^{2}+\lambda / 20, \\
\lambda^{\prime} & =-2 y-2 \lambda y, \\
y(0) & =2, \quad y(10)=1,
\end{array}\right\}
$$

MSB 4.15 di atas diimplementasikan dalam SCILAB sebagai berikut ini.

Persamaan diferensialnya didefinisikan dengan skrip berikut

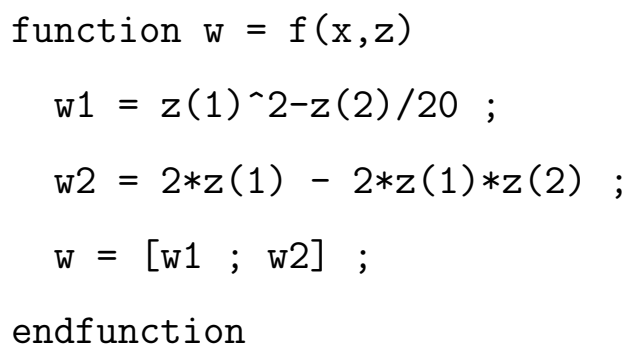

Untuk persamaan tersebut di atas, diperlukan matriks Jacobian, yang ditulis dengan skrip seperti berikut ini

function $w=d f(x, z)$ 
$\mathrm{w}=[2 * \mathrm{z}(1),-1 / 20 ;-2-2 * \mathrm{z}(2),-2 * \mathrm{z}(1)] ;$

endfunction

Sementara syarat batasnya diberikan oleh

function $w=g(i, z)$

if $i==1$ then $w=z(1)-2$,

else $w=z(1)+1$

end

endfunction

Untuk syarat batas tersebut di atas, diperlukan matriks Jacobian, yaitu

function $w=\operatorname{dg}(i, z)$

$\mathrm{W}=\left[\begin{array}{ll}1 & 0\end{array}\right]$;

endfunction

MSB di atas, diselesaikan di atas selang $[0,10]$ dengan lebar kisi $\Delta t=0.1$ yang seragam, berikut sejumlah parameter yang diperlukan, yaitu

$t t=0: 0.1: 10 ;$

ncomp $=2 ;$ nrec $=1$;

$\mathrm{m}=\left[\begin{array}{ll}1 & 1\end{array}\right] ; \mathrm{k}=4$;

$n \max =200$;

mstar $=2$;

$\mathrm{kd}=\mathrm{k} * \mathrm{ncomp}$;

$k d m=k d+m s t a r$

nsizei=kdm+3;

ip6=nmax*nsizei ;

nsizef $=4+3 *$ mstar $+(5+k d) * k d m+(2 * m s t a r-n r e c) * 2 * m s t a r ;$

ip5=nmax $*$ nsizef ; 


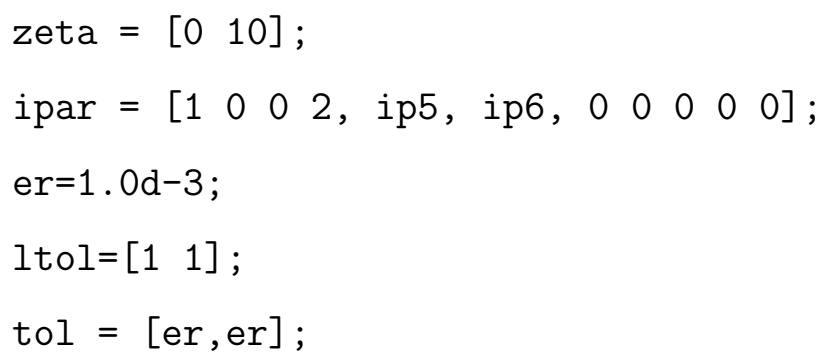

Dan kita berikan funsi tebakan awal, yaitu

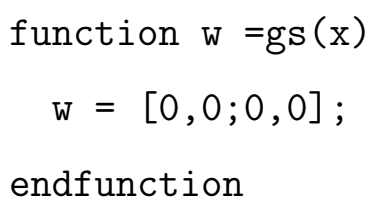

Kemudian untuk memperoleh solusi numerik MSB, diberikan dalam skrip SCILAB berikut

$z z=$ bvode $(t t, 2, \mathrm{~m}, 0,10$, zeta, ipar, 1 tol, tol, 0,f, df ,g, dg, gs $) ;$

control $=-(1 / 20) * z z(2,:)$;

Solusi numerik yang diperoleh, ditampilkan oleh Scilab dengan memberikan skrip berikut ini

$\operatorname{plot} 2 d(t t, z z(1,:))$;

plot2d (tt, control);

plot2d(tt, control, style $=-1)$;

yang tampilan grafisnya diperlihatkan pada gambar 2 .

\section{Beberapa Contoh MKO Sebagai MSB}

Berikut diberikan beberapa contoh MSB yang berasal dari MKO [15], sehingga dapat diuji menggunakan bvode dalam SCILAB. 


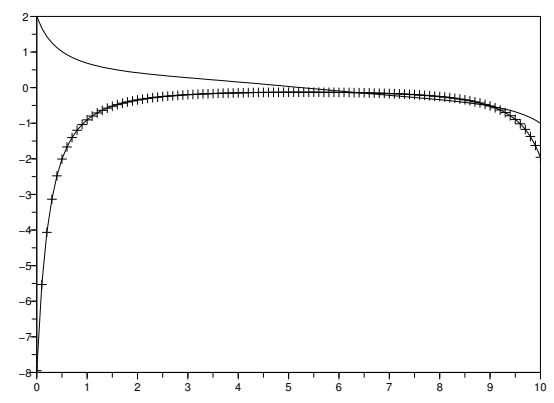

Gambar 4.2: Optimal y (garis) dan kontrol $v$ (garis-x) untuk contoh 2.

\section{Contoh 1.}

Pandang sistem berikut

$$
\begin{aligned}
& x_{1}^{\prime}(t)=x_{2}(t) \\
& x_{2}^{\prime}(t)=-x_{2}(t)+u(t)
\end{aligned}
$$

(a) Perhatikan fungsional ukuran kinerja (performance measure):

$$
J(u)=\int_{0}^{t_{f}} \frac{1}{2} u^{2}(t) d t
$$

dengan syarat batas:

$$
x(0)=0 ; \quad x(2)=\left[\begin{array}{ll}
5 & 2
\end{array}\right]^{T}
$$

(b) Perhatikan fungsional ukuran kinerja (performance measure):

$$
J(u)=\frac{1}{2}\left(x_{1}(2)-5\right)^{2}+\frac{1}{2}\left(x_{2}(2)-2\right)^{2}+\int_{0}^{t_{f}} \frac{1}{2} u^{2}(t) d t
$$

dengan syarat batas:

$$
x(0)=0 ; \quad x(2) \text { bebas }
$$

(c) Perhatikan fungsional ukuran kinerja (performance measure) sebagaimana halnya di (a) dengan syarat batas :

$$
x(0)=0 ; \quad x_{1}(2)+5 x_{2}(2)=15
$$




\section{Contoh 2}

Diberikan sistem integral:

$$
\begin{aligned}
& x_{1}^{\prime}(t)=x_{2}(t) \\
& x_{2}^{\prime}(t)=u(t)
\end{aligned}
$$

Dengan fungsional yang harus diminimumkan :

$$
J(u)=\int_{0}^{t_{f}} \frac{1}{2} u^{2}(t) d t
$$

cari kontrol optimal dengan syarat batas berbentuk:

$$
x(0)=[12]^{T}, \quad x_{1}\left(t_{f}\right)=3, \quad x_{2}\left(t_{f}\right) \text { bebas }
$$

\section{Contoh 3.}

Diberikan sistem integral:

$$
\begin{aligned}
& x_{1}^{\prime}(t)=x_{2}(t) \\
& x_{2}^{\prime}(t)=u(t)
\end{aligned}
$$

Minimumkan waktu akhir:

$$
T=\int_{0}^{t_{f}} d t
$$

agar states kembali ke titik origin:

$$
x(0)=\left[\begin{array}{ll}
2 & 2
\end{array}\right]^{T}, x\left(t_{f}\right)=\left[\begin{array}{ll}
0 & 0
\end{array}\right]^{T},|u| \leq 1
$$




\section{Contoh 4.}

Contoh berikut menguraikan ekonomi negara yang sedang tumbuh yang mengalami kesulitan akibat tingkat pengangguran yang tinggi diakibatkan struktur bisnis. Diperlukan kebijakan yang menuju pertumbuhan yang stabil dan tanpa pengangguran. Data menggunakan data Aljazair pada tahun 1961.

Pemodelan ekonomi berdasarkan apa yang dirumuskan oleh [12], yang memasukkan satu variable kontrol kendala dan satu variable state berkendala. Wick [13], merumuskannya sebagai masalah syarat batas, dan menyelesaikannya dengan teknik shooting.

Persamaan diferensial yang digunakan menimbang dua kasus yang diberikan sebagai berikut, dengan $x \in[0,1]$ peubah bebas, yakni

- Kasus 1. Lintasan tak berkendala $\left(g:=m \sigma e^{\gamma x T}-z<0\right)$ :

$$
\begin{aligned}
\dot{y} & =\alpha u y T \\
\dot{z} & =\alpha(1-u) y T \\
\dot{\lambda}_{y} & =-\left(\lambda_{y} \alpha u+\lambda_{z} \alpha(1-u)\right) T \\
\dot{\lambda}_{z} & =\dot{\lambda}_{r}=\dot{\ell}_{0}=\dot{T}=0
\end{aligned}
$$

- Kasus 2. Lintasan kendala $(g:=0)$, persamaan diferensial untuk $\dot{\lambda}_{y, z, r}$ :

$$
\begin{aligned}
& \dot{\lambda}_{y}=-\lambda_{y} \alpha T \\
& \dot{\lambda}_{z}=0 \\
& \dot{\lambda}_{r}=\left(\lambda_{y}-\lambda_{z}\right) \gamma^{2} z T
\end{aligned}
$$

Dengan konstanta $\alpha=0.25, \sigma=3.1, \gamma=0.125, A=B=4$ dan $m=0.45$. Peubah adjoint $\lambda_{z}$ dan $\lambda_{r}$ diskontinu di titik $x_{1}$ di lintasan terkendala

$$
\begin{aligned}
& \left.\lambda_{z}\right|_{x=x_{1}} ^{+}=\left.\lambda_{z}\right|_{x=x_{1}} ^{-}-\ell_{0} \\
& \left.\lambda_{r}\right|_{x=x_{1}} ^{+}=\left.\lambda_{r}\right|_{x=x_{1}} ^{-}+\ell_{0} m \sigma \gamma e^{\gamma x_{1} T}
\end{aligned}
$$


Variabel kontrol $u$ memenuhi :

$$
\left\{\begin{array}{lll}
1, & \text { jika } x<x_{1}(\text { titik awal }) ; & g<0 \\
1-\frac{\gamma z}{\alpha y}, & \text { pada lintasan kendala } ; & g=0 \\
0, & \text { jika } x>x_{2}(\text { titik akhir }) ; & g<0
\end{array}\right.
$$

Syarat batas yang harus dipenuhi :

$$
\begin{aligned}
y(0) & =1 ; y(1)=A e^{\gamma T}, \\
z(0) & =\sigma ; z(1)=B e^{\gamma T}, \\
\lambda_{y}(0) & =1 \\
\left.H\right|_{x=0} & =\left.\left[-T+\lambda_{y} \dot{y}+\lambda_{z} \dot{z}+\lambda_{r} T\right]\right|_{x=0}=0 \quad \text { (Hamiltonian) } \\
\left.H\right|_{x=1} & =0
\end{aligned}
$$

\section{Penutup}

Telah disampaikan bagaimana Masalah KO dapat diselesaikan sebagai masalah syarat batas, penggunaan MKO sering muncul sebagai model dari berbagai bidang ilmu. Karena untuk mendapatkan solusi analitik tidak selalu tersedia, metode numerik menjadi salah satu cara untuk memperoleh solusinya. Selain itu, dengan tersedianya rutin yang memudahkan pengguna untuk menyelesaikan MSB secara numerik, dimungkinkan melakukan simulasi secara berulang untuk menguji berbagai skenario pemodelan yang menggunakan MKO. Tulisan ini merupakan tutorial bagaimana menggunakan simulasi MSB dalam lingkungan problem solving environment SCILAB yang bersifat open source untuk menyelesaikan MKO.

Perlu kiranya pengujian lebih lanjut atas rutin ini, seperti halnya dilakukan oleh [11] yang menguji rutin simulasi MSB di lingkungan komersial MATLAB. Pengujian beragam MSB dari pelbagai bidang ilmu sebagaimana diberikan oleh [2], dapat diujikan di lingkungan SCILAB untuk bahasan lanjutan. Sedangkan untuk MKO, pengujian berbagai kasus di [3] dan [15], yang memberikan serangkaian contoh MKO sebagai MSB, selain itu sebagaimana 
ditunjukkan di [10], bahwa syarat perlu dari MKO merupakan MSB dengan titik batas majemuk (multipoint BVP) memungkinkan bvode di SCILAB untuk digunakan. Ragam permasalahan MKO disampaikan di buku [9], yang membuka wawasan pentingnya MKO di dalam teknologi maupun ekonomi. 


\section{Bibliografi}

[1] U. Ascher, J. Christiansen, dan R.D. Russel, 1981, "Collocation Software for BoundaryValue ODEs", ACM Transactions on Mathematical Software, Vol. 7, No.2, .

[2] U. Ascher, R. M. Mattheij, dan R.D Russel, Numerical Solution of Boundary Value Problem, Prentice-Hall, Englewood Cliffs, New Jersey.

[3] S. N. Avvakumov and Yu.N. Kiselev, 2000, Boundary value problem for ordinary differential equations with applications to optimal control, Spectral and evolution problems, V10, pp 147-155

[4] S.L. Campbell, J-P. Chancelier, dan R. Nikoukhah, 2005, Modeling and Simulation in Scilab/Scicos, Springer

[5] D.J. Higham dan N.J. Higham,2000, MATLAB Guide. SIAM.

[6] J. Kierzenka dan L. Shampine, 2001, " A BVP solver on residual control and the Matlab PSE", ACM Transactions on Mathematical Software, Vol. 27, No.3, 299-316.

[7] C.B. Moler,2004, Numerical Computing with MATLAB, SIAM.

[8] Paulus, E., M. Suryani, I. Suryana, D. Chaerani, 2018, Perangkat Komputasi Numerik SCILAB, deepublish.

[9] Pesch, H.J., 2002. Schlsseltechnologie Mathematik: Einblicke in aktuelle Anwendungen der Mathematik. Springer-Verlag.

[10] Pesch, H.J., 1994. A practical guide to the solution of real-life optimal control problems. Control and cybernetics, 23(1), p.2. 
[11] L. Shampine, J. Kierzenka, dan M. Reichelt, Solving Boundary Value Problems for Ordinary Differential Equations in Matlab with bvp4c, [http://www.mathworks.com/support/solutions/files/s8314/bvp_paper.pdf]

[12] Stoleru, L.G., 1965, An optimal policy for economic growth, Econometrica: Journal of the Econometric Society, pp.321-348.

[13] Wick, R., 1973, Numerische Loesung volkswirschaftlicher Variationsprobleme mit Zustandsbescrankungen unter Anwendung der Mehrzielmethode. Universitaet zu Koln, Mathematisches Institut, Diplomarbeit (1973).

[14] Layar bantuan SCILAB untuk rutin bvode.

[15] Wang, Xuezhong, 2009, Solving optimal control problems with MATLAB: Indirect methods, ISE Dept., NCSU, Raleigh, NC, 


\section{Bab 5}

\section{Prinsip Maksimum Pontryagin Dalam Masalah Kontrol Optimum Stokastik}

Kontrol Optimum Stokastik merupakan cabang matematika yang relatif baru perkembangannya. Terdapat dua pendekatan untuk menentukan solusi masalah kontrol optimum stokastik, yaitu prinsip maksimum Pontryagin dan program dinamis Bellman. Tulisan ini menyajikan prinsip maksimum untuk masalah kontrol optimum stokastik dan aplikasinya dalam masalah portofolio dan konsumsi. Merton(1971) menyelesaikan masalah konsumsi dan portofolio dengan menggunakan pendekatan program dinamis. Dengan hasil yang diperoleh oleh Merton sebagai patokan, masalah konsumsi dan portofolio diselesaikan dengan pendekatan prinsip maksimum.

\section{Pendahuluan}

Teori kontrol optimum stokastik merupakan cabang ilmu matematika yang masih relatif baru apabila dibandingkan dengan teori kontrol optimum deterministik. Studi tentang kontrol optimum stokastik ini baru berjalan dalam beberapa dekade terakhir. Namun demikian, penggunaan kontrol optimum stokastik sangat menarik. Aplikasi kontrol optimum stokastik sangat luas, antara lain pada bidang-bidang teknik/rekayasa, pengendalian satelit, keuang- 
an, ekonomi, masalah produksi dan inventori, dan masalah konsumsi sumber daya alam, seperti yang dapat dilihat dalam Benes, Shepp dan Witsenhausen (1980), Bensoussan, Hurst dan Naslund (1974), Bensoussan, Kleindorfer dan Tapiero (1980), Merton (1971), Sethi dan Thompson (1981). Pada umumnya, aplikasi kontrol optimum tersebut menggunakan pendekatan program dinamis. Sedangkan penggunaan prinsip maksimum dapat dilihat pada Haussmann (1981).

Masalah kontrol optimum stokastik yang menjadi perhatian dalam tulisan ini adalah dalam bentuk berikut ini : Ingin diminimumkan fungsi ongkos/biaya

$$
J(u(t))=E\left(\int_{0}^{T} f(x(t), u(t), t) d t+S(x(T))\right.
$$

dengan kendala dalam bentuk persamaan diferensial stokastik atau persamaan diferensial Itô

$$
\begin{aligned}
d x(t) & =\alpha(x(t), u(t), t) d t+\sigma(x(t), u(t), t) d B(t) \\
x(o) & =x_{0}
\end{aligned}
$$

dengan $u(t)$ adalah fungsi peubah kontrol yang nilainya terdapat dalam himpunan bagian tertutup $R^{m}$, peubah $x(t)$ merupakan trajektori atau state, $B(t)$ adalah gerak Brown standar, $E$ melambangkan nilai harapan, serta $f, S, \alpha$ dan $\sigma$ adalah fungsi-fungsi yang diberikan. Dalam persamaan diferensial Itô, fungsi $\alpha$ dan fungsi $\sigma$ berturut-turut disebut sebagai koefisien drift dan koefisien difusi.

Bab ini memiliki dua tujuan. Tujuan pertama adalah untuk menyajikan prinsip maksimum yang memiliki peranan penting dalam kontrol optimum- stokastik. Prinsip maksimum dalam masalah kontrol optimum stokastik telah ditelaah, seperti yang dilaporkan dalam beberapa makalah, misalnya dalam Kushner (1972), Haussmann (1981), (1986), Bensoussan (1982a) dan Bensoussan, et. al. (1974). Namun demikian, dalam tulisan tersebut, peubah kontrol hanya terdapat dalam koefisien drift. Sehingga, teknik prinsip maksimum ini tidak dapat digunakan untuk, misalnya masalah konsumsi dan portofolio, seperti yang dikembangkan oleh Merton (1971). Untungnya, dalam tulisan mereka yang sangat menarik, Bensoussan (1982b), Elliott (1990) dan Peng (1990) merumuskan prinsip maksimum untuk masalah kontrol optimum stokastik apabila kontrol juga terdapat dalam koefisien difusi. 
Bensoussan (1982b) memfokuskan pembahasan pada masalah kontrol optimum stokastik untuk masalah dengan himpunan kontrol admissible merupakan himpunan konveks. Akan tetapi, perhitungan Bensoussan ini terlalu rumit karena melibatkan integran stokastik yang tidak diketahui. Elliott (1990) membuat perhitungan menjadi lebih sederhana dengan menggunakan hasil-hasil pada sifat terturunkan atau diferensiabel solusi persamaan diferensial stokastik yang bergantung pada parameter. Sementara Peng (1990) membahas masalah kontrol optimum stokastik untuk himpunan kontrol admissible yang tidak harus dalam bentuk konveks.

Tujuan kedua tulisan ini adalah menyajikan aplikasi prinsip maksimum pada masalah khusus, yaitu masalah konsumsi dan portofolio. Merton (1971) merupakan orang pertama yang menentukan solusi dari masalah ini. Teknik kontrol optimum yang digunakan oleh Merton adalah teknik program dinamis. Dengan menurunkan persyaratan keoptimalan, Merton berhasil menentukan solusi masalah konsumsi dan portofolio tersebut secara eksplisit. Dengan menggunakan solusi yang diperoleh Merton sebagai patokan, akan ditentukan solusi masalah konsumsi dan portofolio dengan menggunakan prinsip maksimum.

Sistematika penulisan selanjutnya adalah sebagai berikut. Dalam bagian kedua disajikan prinsip maksimum stokastik. Pada bagian ketiga disajikan masalah konsumsi dan portofolio serta solusinya seperti yang dikembangkan oleh Merton. Selanjutnya dalam bagian keempat digunakan prinsip maksimum untuk menyelesaikan masalah konsumsi dan portofolio Merton. Pada bagian terakhir, diberikan kesimpulan dan diskusi tentang hasil-hasil pada prinsip maksimum.

\section{Prinsip Maksimum Stokastik}

Masalah kontrol optimum stokastik yang akan menjadi pokok bahasan dalam tulisan ini adalah dalam bentuk berikut ini :

Minimumkan fungsi biaya

$$
J[u(t)]=E\left\{\int_{0}^{T} f[x(t), u(t), t] d t+S[x(T)]\right\}
$$


dengan kendala dalam bentuk persamaan diferensial stokastik

$$
\begin{aligned}
d x(t) & =\alpha(x(t), u(t), t) d t+\sigma(x(t), u(t), t) d B(t) \\
x(0) & =x_{0}
\end{aligned}
$$

Dalam masalah kontrol optimum stokastik di atas, $u(t)$ merupakan peubah kontrol yang nilainya terdapat dalam himpunan bagian dari $R^{m}$, yang bersifat tertutup dan konveks, sedangkan $x(t)$ merupakan trajektori atau peubah keadaan (state) dari sistem, $B(t)$ adalah gerak Brown dalam bentuk standar, operator $E$ merepresentasikan nilai harapan matematika, dan $f, S, \alpha$, dan $\sigma$ merupakan fungsi-fungsi yang diberikan. Dalam bagian ini akan disajikan syarat perlu untuk adanya kontrol optimum, yang dikenal dengan prinsip maksimum. Juga dibicarakan ketersediaan syarat cukup untuk kontrol supaya menjadi kontrol optimum.

Terdapat banyak kajian yang berkaitan dengan penurunan syarat perlu untuk adanya kontrol optimum. Beberapa diantaranya adalah kajian dari Kushner (1972), Bensoussan (1982), Bensoussan, et.al (1974), Haussmann (1986), Elliott (1990) dan Peng (1990). Untuk masalah kontrol optimum stokastik dengan koefisien difusi konstanta, Bensoussan, et.al (1974) menurunkan prinsip maksimum menggunakan pendekatan program dinamis. Penurunan ini, menghasilkan himpunan kontrol yang admissible berupa himpunan konveks, yang berujung pada syarat cukup untuk kontrol optimum. Sementara itu, untuk masalah kontrol optimum stokastik dengan koefisien difusi hanya bergantung pada waktu $t$ dan peubah state $x(t)$, penurunan syarat perlu dapat ditemukan dalam Kushner (1972), Haussmann (1986) dan juga dalam Bensoussann (1982). Kajian Haussmann (1986) menunjukkan bahwa, dengan persyaratan tertentu misalnya persyaratan himpunan kontrol yang admissible berupa himpunan konveks, prinsip maksimum juga merupakan syarat cukup untuk kontrol optimum.

Untuk masalah kontrol optimum stokastik dengan bagian difusi dibolehkan bergantung pada peubah kontrol, penurunan prinsip maksimum ditelaah antara lain oleh Bensoussann (1982), Elliott (1990) dan Peng (1990). Bensoussann dan Elliott memberikan fokus pembahasan mereka pada masalah kontrol optimum stokastik dengan himpunan kontrol admissible berupa himpunan konveks. Pada kenyataannya, Elliott membuat penyederhanaan perhitungan Bensoussann. Sementara itu Peng (1990) membahas prinsip maksimum untuk ma- 
salah kontrol optimum stokastik yang lebih umum, yaitu untuk masalah kontrol dengan himpunan kontrol yang admissibel tidak harus berupa himpunan konveks.

Dari pembahasan di atas dapat disimpulkan bahwa banyak cara untuk menurunkan prinsip maksimum, misalnya melalui prinsip keoptimalan Bellman. Penurunan dalam tulisan ini mengikuti pendekatan yang digunakan oleh Bensoussann. Alasan utama adalah karena kajian Bensoussann merupakan referensi yang sudah baku. Selain itu, penyajian Bensoussann relatif mudah diikuti, dan yang lebih penting lagi, metode Bensoussann memenuhi kriteria aplikasi masalah yang akan dibahas dalam tulisan ini.

\section{Perumusan Masalah}

Misalkan $(\Omega, F, P)$ merupakan ruang peluang yang dilengkapi dengan filtrasi $F^{t}$. Misalkan $B(t)$ merupakan gerak Brown standar yang nilainya terdapat di $R^{n}$. Kita asumsikan bahwa

$$
F^{t}=\{B(t): 0 \leq s \leq t\}
$$

adalah $\sigma$-aljabar yang dibangun oleh $B(t)$.

Perhatikan sistem kontrol stokastik

$$
\begin{aligned}
d x(t) & =\alpha(x(t), u(t), t) d t+\sigma(x(t), u(t), t) d B(t) \\
x(0) & =x_{0}
\end{aligned}
$$

dan asumsikan bahwa fungsi $\alpha$ dan $\sigma$ keduanya adalah fungsi kontinu dan terturunkan terhadap $x$ dan $u$, dan juga asumsikan bahwa $\alpha_{x}, \alpha_{u}, \sigma_{x}, \sigma_{u}$ merupakan fungsi-fungsi berbatas. Misalkan $L_{F}^{2}(0, t)=\left\{u(t) \in L^{2}\left(\Omega, F^{t}, P ; R^{m}\right)\right\}$ merupakan ruang bagian Hilbert dari $L^{2}$. Misalkan $U_{a d}$ berupa himpunan bagian dari $R^{m}$, dan $U_{a d}$ adalah himpunan tak hampa, tertutup, dan konveks. Definisikan himpunan semua kontrol yang admissible

$$
U=\left\{u \in L_{F}^{2}(0, T): u(t) \in U_{a d}, \text { a.e., a.s. }\right\}
$$

Catatan : a.e. merupakan singkatan untuk almost every where, sedangkan a.s. merupakan singkatan untuk almost surely. 
Contoh 5.1 Himpunan kontrol admissible $U$ adalah himpunan konveks dan tertutup dan $U \subset L_{F}^{2}(0, T)$.

Contoh 5.2 Karena asumsi bahwa $\alpha(x, u, t)$ dan $\sigma(x, u, t)$ adalah fungsi-fungsi yang kontinu dan terturunkan serta turunannya terhadap $x$ dan u berbatas, maka untuk sebarang kontrol admissible $u \in U$, persamaan diferensial stokastik sistem kontrol persamaan (5.6) dapat ditentukan solusinya.

Misalkan diasumsikan $f(x, u, t)$ berupa fungsi kontinu dan terturunkan serta turunannya terhadap $x$ dan $u$ berbatas. Juga diasumsikan bahwa fungsi $S$ merupakan fungsi kontinu dan terturunkan serta turunan terhadap $x$ berbatas. Masalah kontrol optimum stokastik dapat dituliskan menjadi masalah meminimumkan fungsional biaya diantara kontrol-kontrol yang admissible $U$

$$
J[u(t)]=E\left\{\int_{0}^{T} f(x(t), u(t), t) d t+S(x(T))\right\}
$$

terhadap kendala

$$
\begin{aligned}
d x(t) & =\alpha(x(t), u(t), t) d t+\sigma(x(t), u(t), t) d B(t) \\
x(0) & =x_{0}
\end{aligned}
$$

Contoh 5.3 Dalam literatur, teknik yang digunakan untuk menyelesaikan masalah meminumkan fungsional objektif disebut teknik prinsip minimum. Karena meminimumkan fungsional adalah identik dengan memaksimumkan negatif dari fungsional tersebut, maka istilah prinsip maksimum tetap dapat digunakan.

Notasi : Notasi berikut akan digunakan dalam pembahasan selanjutnya :

1. Operator ${ }^{\prime *}$ ' menyatakan transpos

2. Operator $<., .>$ menyatakan hasil kali dalam atau inner product 


\section{Prinsip Maksimum Stokastik}

Pada bagian ini disajikan syarat perlu untuk kontrol optimum stokastik, yang dikenal dengan Prinsip Maksimum Stokastik. Teorema berikut ini muncul pertama kali dalam Peng(1990).

Teorema 5.1 (Prinsip Maksimum Stokastik)

Diberikan masalah kontrol optimum stokastik yang meminimumkan fungsional objektif persamaan (5.7) terhadap kendala persamaan (5.9) dan semua asumsi seperti sebelumnya dipenuhi. Misalkan $u(t)$ suatu kontrol optimum, dan $x(t)$ merupakan trayektori optimal yang berkaitan dengan kontrol optimum seperti yang didefinisikan oleh persamaan (5.9). Peubah $p(t)$ menyatakan peubah adjoint yang didefinisikan oleh persamaan

$$
\begin{aligned}
-d p & =\left[\left(\alpha_{x}^{*} p+f_{x}\right)-<\sigma_{x}^{*}, K>\right]+K d B(t) \\
p(T) & =S_{x}(x(T))
\end{aligned}
$$

dengan $K$ didefinisikan oleh

$$
K(t)=\sigma_{x}^{*}(t) p(t)-\Psi^{*}(t) G(t)
$$

dan matriks $\Psi$ memenuhi persamaan diferensial

$$
\begin{aligned}
d \Psi & =-<\Psi \sigma_{x}, d B>+\left[<\Psi \sigma_{x}, \sigma_{x}>-\Psi \alpha_{x}\right] d t \\
\Psi(0) & =I,
\end{aligned}
$$

dengan I merupakan matriks identitas, sedangkan $G$ memenuhi persamaan integral

$$
E^{F^{t}}\{A\}=E\{A\}+\int_{0}^{t} G(s) d B(s)
$$

dengan

$$
A=Q^{*}(T) S_{x}(x(T))+\int_{0}^{T} Q^{*}(s) f_{x}(x(s), u(s), s) d s
$$

dan matriks $Q$ memenuhi

$$
\begin{aligned}
d Q & =\alpha_{x} Q d t+<\sigma_{x} Q, d B> \\
Q(0) & =I .
\end{aligned}
$$


Definisikan fungsi Hamilton berikut ini

$$
H(x, u, t ; p, K)=p \cdot \alpha(x, u, t)+f(x, u, t)-\operatorname{tr} K \sigma^{*}(x, u, t)
$$

maka diperoleh

$$
\frac{\partial H}{\partial v}(x(t), u(t), t ; p(t), K(t)) .(v-u(t)) \geq 0 \text {, a.e.t, a.s., } \forall v \in U \text {. }
$$

Bukti : Bukti teorema ini dapat dilihat dalam Syahril (1991).

Contoh 5.4 Persamaan adjoint (5.10) bergantung pada peubah stokastik yang tidak diketahui $G$ yang didefinisikan oleh persamaan (5.13). Persamaan integrasi (5.13) ditemukan oleh Kunita-Watanabe, seperti yang dilaporkan oleh Peng(1990). Sangat sulit untuk menentukan solusi persamaan adjoint (5.10).

Untuk menghindari kesulitan tersebut, Elliott (1990) menemukan representasi yang sangat elegan untuk peubah adjoint $p$. Menurut Elliott(1990), peubah adjoint haruslah memenuhi persamaan

$$
\begin{aligned}
p_{t}(t) & +p_{x}(t) g(t)+l_{x}(t)+p(t) g_{x}(t) \\
& +\frac{1}{2} \sum_{i=1}^{n} p_{x x}(t) \sigma^{(i)}(t) \times \sigma^{(i)}(t)=0, \\
p(T) & =h_{x}(x(T)) .
\end{aligned}
$$

Fungsi Hamilton yang bersesuaian diberikan oleh

$$
H(x, v, t, p)=p g(x, v, t)+l(x, v, t)+\sum_{i=1}^{n} p_{x}(t) \sigma^{(i)}(x, u, t) \sigma^{(i)}(x, v, t)
$$

dan prinsip maksimum diberikan oleh

$$
\frac{\partial H}{\partial v}(x(t), u(t), t, p \cdot(v-u(t)) \geq 0
$$

a.e. $t$, hampir pasti untuk semua $v \in U$. 


\section{Masalah Portofolio dan Konsumsi}

Dalam model pemilihan portofolio dan konsumsi, Merton (1971) merumuskan persamaan kekayaan dalam bentuk persamaan diferensial stokastik. Persamaan ini dikenal dengan nama persamaan budget. Merton (1971) mengasumsikan harga aset memiliki distribusi log normal, sehingga cukup dilihat hanya 2 aset saja, yaitu aset bebas resiko dan aset beresiko. Harga setiap aset bebas resiko, dilambangkan oleh $P_{1}(t)$, berkembang mengikuti persamaan diferensial biasa

$$
d P_{1}(t)=r P_{1}(t) d t
$$

dengan $r$ menyatakan rate of return atau tingkat imbal hasil, sedangkan harga aset beresiko, dilambangkan oleh $P_{2}(t)$, berkembang mengikuti persamaan diferensial stokastik

$$
d P_{2}(t)=\alpha P_{2}(t) d t+\sigma P_{2}(t) d B(t)
$$

dengan $\alpha$ melambangkan rata-rata perubahan harga per satuan waktu, dan $\sigma$ melambangkan variansi dari perubahan harga per satuan waktu. Parameter $r, \alpha, \sigma$ adalah konstanta dan $\{B(t): t \geq 0\}$ merepresentasikan gerak Brown bernilai real.

Misalkan $W(t), \quad t \geq 0$ menyatakan kekayaan pada waktu $t$ dari pemodal yang menginvestasikan kekayaannya pada kedua tipe aset di atas. Misalkan $u_{1}(t)$ menyatakan proporsi kekayaan yang diinvestasikan pada aset beresiko pada waktu $t$, dan $u_{2}(t)$ menyatakan tingkat konsumsi pada waktu $t$. Maka persamaan budjet atau kekayaan pemodal tersebut adalah

$$
\begin{aligned}
d W(t)= & {\left[1-u_{1}(t)\right] W(t) r d t+u_{1}(t) W(t)[\alpha d t+\sigma d B(t)] } \\
& -u_{2}(t) d t \\
W(0)= & W_{0},
\end{aligned}
$$

dengan $W_{0}>0$ menyatakan jumlah kekayaan awal. Kontrol yang digunakan dalam masalah ini adalah kontrol 2-dimensi, $u(t)=\left(u_{1}(t), u_{2}(t)\right)$, dengan batasan $0 \leq u_{1}(t) \leq 1$, dan $u_{2}(t) \geq 0$.

Masalah pemilihan portofolio dan konsumsi optimum bagi pemodal yang hidup sampai 
tahun ke- $T$ dirumuskan sebagai berikut

$$
J[u(t), t]=\max E\left\{\int_{0}^{T} U\left[u_{2}(t), t\right] d t+S[W(T), T]\right\}
$$

dengan kendala persamaan (5.23), dan fungsi utilitas $U$ diasumsikan berupa fungsi konkaf (cembung) dalam $u_{2}$, dan fungsi warisan $S$ diasumsikan bersifat konkaf dalam $W$.

Misal diasumsikan fungsi utilitas untuk pemodal $U\left[u_{2}(t), t\right]$ dapat dituliskan dalam bentuk

$$
U\left[u_{2}(t), t\right]=\exp (-\rho t) V\left[u_{2}(t)\right]
$$

dengan $\rho>0$ merupakan tingkat diskonto, fungsi $V$ merupakan anggota fungsi-fungsi utilitas yang memiliki risk-aversion bersifat positif dan hiperbola dalam konsumsi. Fungsi $V$ ini dapat dituliskan dalam bentuk

$$
V\left[u_{2}(t)\right]=\frac{1-q}{q}\left[\frac{b u_{2}(t)}{1-q}+n\right]^{q}
$$

dengan batasan $q \neq 1, \quad b>0, \quad \frac{b u_{2}(t)}{1-q}+n>0, \quad n=1$ jika $q=-\infty$. Sehingga, dengan asumsi fungsi warisan $S=0$, masalah pemilihan portofolio dan konsumsi optimum menjadi

$$
J[u(t), t]=\max E\left\{\int_{0}^{T} \exp (-\rho t) V\left[u_{2}(t)\right] d t\right\}
$$

dengan kendala persamaan ( 5.23).

Menggunakan metode program dinamis stokastik, Merton (1971) menurunkan persyaratan keoptimalan

$$
\begin{aligned}
J_{t} & +\left[\frac{(1-q) n}{b}+r W\right] J_{W}-\frac{(\alpha-r)^{2}}{2 \sigma^{2}} \frac{J_{W}^{2}}{J_{W W}} \\
& +\frac{(1-q)^{2}}{q} \exp (-\rho t)\left[\frac{\exp (\rho t) J_{W}}{b}\right]^{\frac{q}{1-q}}=0
\end{aligned}
$$

dengan persyaratan $J(W, T)=0$, dan fungsi $J(W, t)$ merupakan fungsi deterministik. Suatu solusi dari persamaan diferensial parsial ordo dua (5.27) adalah

$$
\begin{aligned}
J(W, t) & =\frac{s b^{q}}{q} \exp (-\rho t)\left[\frac{s\left[1-\exp \left(\frac{-(\rho-q v)(T-t)}{s}\right)\right]}{-q v}\right]^{s} \\
& \times\left[\frac{W}{s}+\frac{n}{b r}[1-\exp (-r(T-t))]\right]^{q}
\end{aligned}
$$


dengan $s=1-q$, dan $v=r+\frac{(\alpha-r)^{2}}{2 s \sigma^{2}}$.

Persamaan untuk portofolio dan konsumsi optimum adalah

$$
\begin{aligned}
& u_{2}(t)=\frac{1-q}{b}\left(\frac{\exp (\rho t) J_{W}}{b}\right)^{\frac{1}{q-1}}-\frac{(1-q) n}{b} \\
& u_{1}(t)=-\frac{(\alpha-r)}{\sigma^{2}} \frac{J_{W}}{J_{W W} W} .
\end{aligned}
$$

Dari persamaan ( 5.28), ( 5.29) dan ( 5.30), portofolio dan konsumsi optimum dapat dituliskan dalam bentuk eksplisit

$$
\begin{aligned}
& u_{2}(t)=\frac{(\rho-q v)\left(W(t)+\frac{s n}{b r}(1-\exp ([r(t-T)])\right.}{s\left(1-\exp \left(\frac{(\rho-q v)(t-T)}{s}\right)\right)}-\frac{s n}{b} \\
& u_{1}(t)=\frac{\alpha-r}{s \sigma^{2}}+\frac{n(\alpha-r)}{b r \sigma^{2} W(t)}(1-\exp (r(t-T))) .
\end{aligned}
$$

Contoh 5.5 Karakteristik utama dalam persamaan (5.31) adalah fungsi konsumsi merupakan fungsi linier dari fungsi kekayaan, dan dalam persamaan (5.32) adalah fungsi investasi berbanding terbalik dengan fungsi kekayaan.

Contoh 5.6 Fleming and Rishel (1975) menyelesaikan masalah portofolio dan konsumsi untuk fungsi utilitas $U\left[u_{2}(t), t\right]=u_{2}^{s}, \quad 0<s<1$. Solusi optimum yang diperoleh adalah $u_{1}^{\star}(t)$ merupakan konstanta dan $u_{2}^{\star}(t)$ merupakan fungsi linier dalam kekayaan $W(t)$.

\section{Aplikasi Prinsip Maksimum Stokastik Pada Model Mer-}

\section{ton}

Untuk aplikasi prinsip maksimum pada masalah Merton, dituliskan kembali masalahnya dalam bentuk berikut ini :

$$
J[u(.)]=E\left\{\int_{0}^{T}-\frac{1-q}{q} \exp (-\rho t)\left[\frac{b u_{2}(t)}{1-q}+n\right]^{q} d t\right\}
$$

dengan kendala persamaan kekayaan

$$
\begin{aligned}
d W(t)= & {\left[r W(t)+(\alpha-r) W(t) u_{1}(t)-u_{2}(t)\right] d t } \\
& +\sigma W(t) u_{1}(t) d B(t) \\
W(0)= & W_{0}
\end{aligned}
$$


Misalkan $u^{\star}(t)=\left(u_{1}^{\star}(t), u_{2}^{\star}(t)\right)$ sebagai kontrol optimum, dan $\hat{W}(t)$ merupakan trajektori optimum yang berkaitan yang didefinisikan oleh

$$
\begin{aligned}
d \hat{W}(t)= & {\left[r \hat{W}(t)+(\alpha-r) \hat{W}(t) u_{1}^{\star}(t)-u_{2}^{\star}(t)\right] d t } \\
& +\sigma \hat{W}(t) u_{1}^{\star}(t) d B(t) \\
\hat{W}(0)= & W_{0} .
\end{aligned}
$$

Peubah adjoint $p(t)$ merupakan solusi dari

$$
\begin{aligned}
-d p(t) & =\left[\left(r+(\alpha-r) u_{1}^{\star}(t) p(t)-<\sigma u_{1}^{\star}(t), K>\right] d t+K d B(t)\right. \\
p(T) & =0 .
\end{aligned}
$$

Menggunakan persamaan (5.16), diperoleh fungsi Hamilton

$$
\begin{aligned}
H\left(\hat{W}, u^{\star}, t ; p, K\right) & =\left[\left(r+(\alpha-r) u_{1}\right) \hat{W}-u^{\star}\right] p \\
& -\frac{(1-q)}{q} \exp (-\rho t)\left(\frac{b u_{2}^{\star}}{1-q}+n\right)^{q}-\operatorname{tr} K \sigma \hat{W} u_{1}^{\star} .
\end{aligned}
$$

Dengan mengaplikasikan prinsip maksimum persamaan (5.17) pada fungsi Hamilton persamaan (5.38), dan dengan membuat turunan $H$ terhadap $u_{1}$ sama dengan nol, menghasilkan

$$
K=\frac{(\alpha-r)}{\sigma} p
$$

Turunan fungsi $H$ terhadap $u_{2}$ sama dengan nol memberikan

$$
p+b \exp (-\rho t)\left(\frac{b u_{2}^{\star}}{1-q}+n\right)^{q-1}=0 .
$$

Fleming dan Rishel (1975) dan Haussmann (1986) menunjukkan bahwa ada kontrol optimum dalam bentuk umpan balik. Berdasarkan ini, ingin dicari fungsi adjoint $p(t)$ demikian rupa sehingga dipenuhi

$$
p(t)=-\frac{\partial L}{\partial W}
$$

dengan $L(W, t)$ melambangkan fungsi deterministik yang tidak diketahui. Dengan menggunakan formula Itô pada persamaan (5.41) akan diperoleh

$$
d p=-\left[\frac{\partial^{2} L}{\partial t \partial W}+\frac{\partial^{2} L}{\partial W^{2}} d \hat{W}+\frac{1}{2} \frac{\partial^{3} L}{\partial W^{3}} d \hat{W}^{2}\right]
$$


Dengan memanfaatkan $d \hat{W}$ seperti dalam persamaan (5.35), dan diaplikasikan pada persamaan (5.42), menghasilkan

$$
\begin{aligned}
d p & =-\left[\frac{\partial^{2} L}{\partial t \partial W}+\left(r \hat{W}+(\alpha-r) \hat{W} u_{1} \star-u_{2}^{\star}\right) \frac{\partial^{2} L}{\partial W^{2}}\right. \\
& \left.+\frac{1}{2} \hat{W}^{2} u_{1}^{\star} \frac{\partial^{3} L}{\partial W^{3}}\right] d t-\sigma \hat{W} u_{1}^{\star} \frac{\partial^{2} L}{\partial W^{2}} d B(t) .
\end{aligned}
$$

Langkah selanjutnya, dengan mensubstitusi $K$ yang didefinisikan dalam persamaan (5.39) kedalam persamaan (5.37), sehingga diperoleh

$$
\begin{aligned}
-d p & =r p d t+\frac{\alpha-r}{\sigma} p d B(t) \\
p(T) & =0 .
\end{aligned}
$$

Dengan identifikasi persamaan (5.43) dan persamaan (5.44), koefisien $d B(t)$ memberikan

$$
\hat{W} u_{1}^{\star} \frac{\partial^{2} L}{\partial W^{2}}=\frac{\alpha-r}{\sigma} p .
$$

Karena menurut persamaan $(5.41) p(t)=-\frac{\partial L}{\partial W}$, maka didapat

$$
u_{1}^{\star}=-\frac{\partial L / \partial W}{\partial^{2} L / \partial W^{2}} \frac{1}{W} \frac{(\alpha-r)}{\sigma^{2}} .
$$

Dari persamaan (5.40) dan persamaan (5.41) diperoleh

$$
u_{2}^{\star}=-\frac{1-q}{b} n+\frac{1-q}{b}\left[\frac{\exp (\rho t)}{b} \frac{\partial L}{\partial W}\right]^{\frac{1}{q-1}} .
$$

Dengan cara yang sama, identifikasi persamaan (5.43) dan persamaan (5.44), koefisien $d t$ menghasilkan

$$
-r \frac{\partial L}{\partial W}=\frac{\partial^{2} L}{\partial t \partial W}+\left[r \hat{W}+(\alpha-r) \hat{W} u_{1}^{\star}-u_{2}^{\star}\right] \frac{\partial^{2} L}{\partial W^{2}}+\frac{1}{2} \sigma^{2} \hat{W}^{2} u_{1}^{\star 2} \frac{\partial^{3} L}{\partial W^{3}} .
$$

Dengan memanfaatkan nilai $u_{1}^{\star}$ dan nilai $u_{2}^{\star}$, dan tanpa kehilangan sifat keumuman, maka dapat ditunjukkan bahwa

$$
\begin{aligned}
L_{t} & +\left[r \hat{W}+\frac{(1-q)}{b} n\right] L_{W}-\frac{(\alpha-r)^{2}}{2 \sigma^{2}} \frac{L_{W}^{2}}{L_{W W}}-\frac{(1-q)}{b} \\
& +\left[\frac{\exp (\rho t)}{b} L_{W}\right]^{\frac{1}{(q-1)}} L_{W} \frac{1-q}{q} \exp (-\rho t)\left[\frac{\exp (\rho t)}{b} L_{W}\right]^{\frac{q}{q-1}}=0 .
\end{aligned}
$$


Persamaan ini tidak lain adalah persyaratan keoptimalan seperti persamaan (5.27) yang diturunkan dengan prinsip program dinamis stokastik. Dengan menggunakan solusi yang diberikan dalam persamaan (5.28) untuk persamaan (5.49), maka dapat ditemukan solusi untuk masalah portofolio dan konsumsi. Solusinya diberikan oleh persamaan (5.31) dan persamaan (5.32).

Contoh 5.7 Untuk masalah khusus ini, prinsip maksimum tidak memberikan bentuk tertutup untuk kontrol $u_{1}^{\star}$, karena fungsi Hamilton merupakan fungsi linier dalam $u_{1}^{\star}$. Sebaliknya, karena fungsi Hamilton bukan fungsi linier dalam $u_{2}^{\star}$, maka prinsip maksimum menghasilkan fungsi kontrol optimum $u_{2}^{\star}$ dalam bentuk tertutup.

Contoh 5.8 Untuk memperoleh $u_{1}^{\star}$ digunakan teknik lain. Teknik ini berdasarkan pada kenyataan bahwa kontrol optimum dapat dituliskan dalam bentuk tertutup, seperti yang dinyatakan oleh Fleming and Rishel (1975). Teknik yang digunakan diawali dengan asumsi bahwa fungsi adjoint merupakan fungsi turunan dari fungsi deterministik yang belum diketahui. Teknik ini berujung pada penentuan kriteria keoptimalan seperti yang dihasilkan oleh teknik program dinamis stokastik.

Dengan mengaplikasikan hasil yang diperoleh Elliott (1990), yaitu persamaan (5.18) dan persamaan (5.19) terhadap masalah portofolio dan konsumsi sebagaimana yang dikembangkan oleh Merton, maka diperoleh proses adjoint $p$ yang memenuhi

$$
\begin{aligned}
p_{t} & +\left[r+(\alpha-r) u_{1}^{\star}\right] p+\left[r \hat{W}+(\alpha-r) \hat{W} u_{1}^{\star}-u_{2}^{\star}\right] p_{W} \\
& +\frac{1}{2} \sigma^{2} \hat{W}^{2} u_{1}^{\star 2} p_{W W}=0, \\
p(T) & =0 .
\end{aligned}
$$

Fungsi Hamilton diberikan dalam bentuk

$$
\begin{aligned}
H(W, u, t, p) & =-\frac{1-q}{q} \exp (-\rho t)\left[\frac{b u_{2}(t)}{1-q}+n\right]^{q}+[r \hat{W} \\
& \left.+(\alpha-r) \hat{W} u_{1}-u_{2}\right] p+\sigma^{2} \hat{W}^{2} u_{1}^{2} p_{W}
\end{aligned}
$$


Pada gilirannya, fungsi Hamilton memberikan kontrol optimum

$$
\begin{aligned}
& u_{1}^{\star}(t)=-\frac{(\alpha-r) p(t)}{2 \sigma^{2} \hat{W} p_{W}} \\
& u_{2}^{\star}(t)=-\frac{1-q}{b} n+\frac{1-q}{b}[-\exp (\rho t) p(t)]^{\frac{1}{q-1}} .
\end{aligned}
$$

\section{Kesimpulan dan Diskusi}

Telah disajikan syarat perlu, yang disebut dengan prinsip maksimum, untuk masalah kontrol optimum stokastik dengan fungsi kontrol terdapat dalam koefisien drift maupun koefisien difusi. Masalah kontrol optimum stokastik yang dibahas merupakan masalah kontrol optimum dengan kontrol admissible berupa himpunan konveks. Kunci utama dalam prinsip maksimum dalam masalah kontrol optimum stokastik adalah peubah adjoint. Penyajian peubah adjoint dalam tulisan ini, dan juga penyajian prinsip maksimum, mengikuti penyajian yang diberikan oleh Bensoussan (1982). Penyajian Bensoussan mengenai peubah adjoint, demikian rupa sehingga peubah adjoint memenuhi persamaan diferensial Itô. Akan tetapi, penyajian Bensoussan ini memunculkan kesulitan dalam penghitungan, karena persamaan diferensial yang dipenuhi melibatkan penghitungan fungsi integran stokastik yang tidak diketahui. Nyatanya, kesulitan penghitungan yang muncul karena Bensoussan menggunakan hasil martingale yang ditemukan oleh Kunita-Watanabe. Dengan demikian, karena kerumitan yang timbul, aplikasi prinsip maksimum, paling tidak untuk masalah portofolio dan konsumsi optimum, tidak lebih baik dari teknik program dinamis stokastik.

Dalam tulisannya yang sangat menarik, Elliott (1990) berhasil mengatasi kerumitan penghitungan Bensoussan mengenai peubah adjoint dengan cara menggunakan sifat dapat diturunkannya (differentiability) persamaan diferensial stokastik. Penyederhanaan yang dilakukan Elliott terutama bergantung pada penyajian fungsi integran stokastiknya Bensoussan. Ternyata, penyajian peubah adjoint memenuhi persamaan diferensial parsial yang bersifat 
bukan stokastik.

Salah satu hasil penting yang ingin dikemukakan disini adalah bahwa terdapat hubungan antara prinsip maksimum dengan program dinamis. Terdapat dua cara dalam mempelajari masalah kontrol optimum stokastik : menggunakan prinsip maksimum yang dikembangkan oleh Pontryagin yang melibatkan proses adjoint $p$, dan dengan menggunakan program dinamis yang dikembangkan oleh Bellman yang melibatkan fungsi nilai $V$. (Definisi fungsi nilai $V$ dapat ditemukan dalam Fleming and Rishel (1975) dan Zhou (1990)). Secara umum, hubungan yang terdapat antara kedua pendekatan ini bersifat demikian rupa sehingga ada hubungan yang erat antara peubah adjoint $p$ dan fungsi nilai $V$. (Untuk detilnya dapat dilihat dalam Zhou (1990)). Elliott(1990) menyatakan bahwa hubungan tersebut demikian rupa sehingga $p_{x}=V_{x x}$. 


\section{Bibliografi}

[1] V.E. Benes, L.A. Shepp and Witsenhausen, 1980, Some Solvable Stochastic Control Problems, Stochastics, vol. 4, pp.39-83

[2] A. Bensoussan, 1982a, Lectures on Stochastic Control, Lecture notes in Mathematics, vol. 972, pp.1-39

[3] A. Bensoussan, 1982b, Stochastic Control by Functional Analysis Methods, North-Holland, Amsterdam

[4] A. Bensoussan, 1986, Current Results and Issues in Stochastic Control, Lecture Notes in Control and Information Sciences, vol. 78, pp. 36-88

[5] A Bensoussan, E.G. Hurst and B. Naslund, 1974, Management Applications of Modern Control Theory, North-Holland, Amsterdam

[6] A. Bensoussan, P. Kleindorfer and C. Tapiero, eds., 1980, Applied Stochastic Control in Econometrics and Management Science, North-Holland, Amsterdam

[7] R.J. Elliott, 1990, The Optimal Control of Diffusions, Applied Mathematcs and Optimization, vol. 22, pp. 229-240

[8] R.J. Elliott and M. Kohlmann, 1988, A Short Proof of Martingale Representation Result, Statistics \& Probability Letters, 6, pp. 327-329

[9] W.H. Fleming and R.W. Rishel, 1975, Deterministic and Stochastic Optimal Control, SpringerVerlag, New York

[10] U.G. Haussmann, 1981Some Examples of Optimal Stochastic Controls or : The Stochastic Maximum Principle at Work, SIAM Review, vol. 23, No. 3, July, pp. 292-307 
[11] U.G. Haussmann, 1986, A Stochastic Maximum Principle for Optimal Control of Diffusions, Pitman Research Notes in Mathematics Series, vol. 151

[12] H.J Kushner, 1972, Necessary Conditions for Continuous Parameter Stochastic Optimization Problems, SIAM Journal Control, vol. 10, No. 3, August, pp. 550-564

[13] R.C. Merton, 1971, Optimum Consumption and Portfolio Rules in a Continuous-Time Model, Journal of Economic Theory, No. 3, December, pp. 373-413

[14] B. Oksendal, 1985, Stochastic Differential Equations, Springer-Verlag, Berlin

[15] S. Peng, 1990, A General Stochastic Maximum Principle for Optimal Control Problems, SIAM Journal Control and Optimization, vol. 28, No. 4, July, pp. 966-979

[16] S.P. Sethi and G.L. Thompson, 1981, Optimal Control Theory : Applications to management Science, Martinus Nijhoff Publishing, Boston

[17] E. Syahril, 1991, A Maximum Principle in Stochastic Optimal Control, Graduate Diploma Project, Department of Applied Mathematics, The University of Adelaide, Adelaide

[18] X.Y. Zhou, 1990, The Connection Between the Maximum Principle and Dynamic Programming in Stochastic Control, Stochastics and Stochastics Reports, vol. 31, pp. 1-13 


\section{SCILAB Singkat}

Scilab merupakan program interaktif yang merdeka dan opensource untuk komputasi matriks. Scilab dikembangkan pada mulanya oleh sekelompok ilmuwan peneliti yang berbasis di INRIA, sebagai alternatif dari produk komersial populer MATLAB. Kini, Scilab dikembangkan secara kolaboratif dalam bentuk konsorsium. Tengoklah homepagenya di www.scilab.org. Dari homepage tersebut, softwarenya dapat diunduh, juga dapat ditinjau berbagai tambahan yang disumbangkan pengguna.

Scilab mulai banyak digunakan sebagai lingkungan kerja penyelesaian masalah (Problem Solving Enviroments) di dunia penelitian bidang rekayasa dan industri (terutama di Perancis). Dan kini mulai banyak digunakan sebagai wahana pembelajaran.

Sejumlah buku pengajaran matematika mempergunakan MATLAB sebagai wahana pembelajaran. Tidak terlalu sulit bagi pengguna Scilab untuk merubahnya ke lingkungan yang diperlukan.

\section{Elemen Data Dasar.}

Elemen dasar yang digunakan Scilab adalah matriks. Saat pengguna membangkitkan matriks, pengguna dengan cepat dapat melakukan perhitungan yang cukup canggih dengan pemrograman seminimum mungkin.

Membentuk matriks dalam Scilab sangatlah mudah. Misalnya untuk membangkitkan 
matriks berikut :

$$
\left(\begin{array}{llll}
1 & 2 & 3 & 4 \\
5 & 6 & 7 & 8 \\
9 & 10 & 11 & 12 \\
13 & 14 & 15 & 16
\end{array}\right)
$$

dengan mudah dapat diketik hal berikut ini :

$A=\left[\begin{array}{lllllllllllllllllll}1 & 2 & 3 & 4 & ; & 5 & 6 & 7 & 8 & ; & 9 & 10 & 11 & 12 & ; & 13 & 14 & 15 & 16\end{array}\right]$

atau dapat pula diketik dengan cara baris demi baris :

$$
A=\left[\begin{array}{llll}
1 & 2 & 3 & 4 \\
5 & 6 & 7 & 8 \\
9 & 10 & 11 & 12 \\
13 & 14 & 15 & 16
\end{array}\right]
$$

Vektor baris dengan jarak sama dengan mudah dibangkitkan dalam Scilab mempergunakan operasi : . Perintah $x=3: 8$ akan membangkitkan sebuah vektor dengan entri bilangan bulat dari 3 hingga 8 dalam Scilab :

$$
\mathrm{x}=3: 8
$$

yang hasilnya sama saja kalau kita mengetikkan dalam Scilab :

$$
x=\left[\begin{array}{llllll}
3 & 4 & 5 & 6 & 7 & 8
\end{array}\right]
$$

Tidak hanya jarak teratur sebesar 1 saja yang dapat dibangkitkan seperti ini. Misalnya,

$$
\mathrm{x}=0.0: 0.25: 1.0
$$

yang hasilnya sama dengan mengetikkan :

$$
\mathrm{x}=\left[\begin{array}{lllll}
0.0 & 0.25 & 0.5 & 0.75 & 1.0
\end{array}\right]
$$




\section{Submatriks}

Untuk merujuk pada kolom atau baris dari matriks dengan mudah diperoleh. Misalnya kita hendak merujuk pada baris ke-4 dari matriks A, dapat kita perintahkan dengan cara :

baris_4 $=A(4,:)$

Maka Scilab akan merespons :

baris_4 =

! $13141516 \quad$ !

tanda : pada $\mathrm{A}(4$, : ) menyatakan seluruh indeks kolom. Begitu pula untuk merujuk pada kolom, misalnya kolom ke-3, kita berikan perintah :

kolom_3 $=A(:, 3)$

Maka Scilab akan merespons :

kolom_3 =

! 3 !

! 7 !

! $11 !$

! $15 !$

Dalam Scilab diberikan kemudahan untuk akses sub-matriks. Misalnya, kita hendak mengambil submatriks di baris-1 sampai 3, dan kolom 2 sampai 4, kita berikan perintah berikut ini :

A_13_24 $=A(1: 3,2: 4)$

Maka Scilab akan merespons : 
A_13_24 =

$\begin{array}{lllll}1 & 2 & 3 & 4 & \text { ! }\end{array}$

! $678 \quad 8$ !

! $101112 \quad$ !

\section{Membangkitkan Matriks.}

Dengan mempergunakan fungsi Scilab yang sudah jadi, pengguna dengan mudah membangkitkan matriks berdasarkan formula yang diinginkan. Misalnya, perintah

$B=\operatorname{rand}(4,4)$

akan membangkitkan matriks B berukuran $4 \times 4$ yang entrinya merupakan bilangan acak di selang $[0,1]$. Fungsi lainnya yang dapat digunakan untuk membangkitkan matriks antara lain eye, zeros, ones dan toeplitz. Untuk membangkitkan matriks segitiga dan diagona tersedia fungsi triu, tril, dan diag .

Perintah membangun matriks dapat digunakan untuk mengkonstruksi matriks berdasarkan partisi. Misalnya, perintah Scilab

$E=[$ eye $(2,2)$ ones $(2,3) ; \operatorname{zeros}(2,2)[1: 3 ; 3:-1: 1]]$

Sehingga akan dibangkitkan matriks :

$$
\mathrm{E}=\left[\begin{array}{lllll}
1 & 0 & 1 & 1 & 1 \\
0 & 1 & 1 & 1 & 1 \\
0 & 0 & 1 & 2 & 3 \\
0 & 0 & 3 & 2 & 1
\end{array}\right]
$$

\section{Aritmetika Matriks}

Aritmetika matriks dalam Scilab cukup sederhana. Perkalian dua buah matriks A dan B dengan mudah dilakukan dengan menuliskan perintah A*B. Penjumlahan dan selisih dua 
buah matriks pula mudah dilakukan dengan memberikan perintah sesederhana berikut ini A+B dan A-B. Sedangkan transposisi matriks dengan mudah dapat menggunakan perintah : A'. Jika c merupakan vektor (kolom) di $\mathrm{R}^{4}$, maka solusi sistem persamaan linear $\mathbf{A x}=\mathbf{c}$ dapat dihitung dengan memberikan perintah :

$$
\mathbf{x}=\mathbf{A} \backslash \mathbf{c}
$$

\section{Fungsi Scilab}

Untuk menghitung nilai eigen dari matriks segi A, cukup mengetikkan spec(A). Sementara vektor eigen dan nilai eigen dapat diperoleh dengan memberikan perintah :

$[X]=\operatorname{spec}(A)$

dengan matriks $D$ berupa matriks diagonal yang pada diagonalnya memuat nilai eigen matrix $A$, sedangkan matriks $X$ yang kolomnya merupakan vektor eigen matriks $A$ yang berkaitan dengan nilai eigen pada diagonal $D$.

Begitu pula beberapa fungsi untuk matriks tersedia misalnya determinan, invers, bilangan kondisi, norm dan rank sebuah matriks yang perintahnya hanya terdiri dari perintah satukata. Faktorisasi matriks seperti LU, QR, Cholesky, dekomposisi Schur dan dekomposisis nilai singular juga dapat dihitung dengan perintah satu-kata. Misalnya, perintah

$\left[\begin{array}{ll}\mathrm{Q} & \mathrm{R}\end{array}\right]=\operatorname{qr}(\mathrm{A})$

akan menghasilkan matriks ortogonal $\mathrm{Q}$ dan matriks segi tiga atas $\mathrm{R}$, dengan ukuran yang sama dengan $\mathrm{A}$, sehingga: $\mathrm{A}=\mathrm{Q}^{*} \mathrm{R}$.

\section{Ciri pemrograman}

Scilab memiliki semua struktur kendali pemrograman sebagaimana ditemukan di pemrograman bahasa tingkat tinggi seperti for, while, dan if. Hal ini memungkinkan pengguna untuk menulis program Scilab berdasarkan kebutuhan mereka dan menggenapkan fungsi 
Scilab yang ada. Beberapa hal yang perlu di catat antara lain, Scilab akan mencetak setiap perintah kecuali bila pada akhir perintah tersebut diberikan titik koma. Bila mempergunakan perintah berulang, sebaiknya dalam setiap pengulangan perintahnya diakhiri dengan titik koma, untuk menghindari hasil antara diperlihatkan di layar.

\section{Scilab file.}

Pengguna dapat memperluas fungsionalitas Scilab dengan menambahkan program baru yang dibutuhkannya. Program di Scilab dituliskan dalam dua jenis yaitu .sci dan .sce keduanya sering dirujuk sebagai Scilab file.

Script files ialah file yang isinya merupakan serangkaian perintah Scilab . Semua variable dalam file ini bersifat global, sehingga nilai dari variabel tersebut akan berubah setiap script ini dijalankan. Sebagai contoh, misalkan seseorang ingin menghitung nolitas dari sebuah matriks, maka disusunlah sebuah script file dengan nama nolitas.sci yang isinya ialah perintah berikut ini :

[n_baris n_kolom] $=\operatorname{size}(A)$;

nol_dim $=$ n_kolom $-\operatorname{rank}(\mathrm{A})$;

Dengan mengeksekusi perintah nolitas akan mengakibatkan kedua baris perintah di atas akan dilaksanakan. Salah satu kelemahan untuk menentukan nolitas seperti di atas ialah, matriksnya selalu bernama A dan nilai variabel $\mathrm{n} \_$baris dan $\mathrm{n} \_$kolom selalu berubah manakala perintah tersebut dilaksanakan. Sebagai pilihan, dapat digunakan function file.

Sebuah function files dimulai dengan sebuah deklarasi funsional yang berbentuk :

$[\operatorname{oarg} 1, \operatorname{oarg} 2, \ldots, \operatorname{oarg} j]=f \_n a m a(\operatorname{inarg} 1, \operatorname{inarg} 2, \ldots$, inargk $)$

Semua varibel dalam functions files bersifat lokal. Bila function files ini dipanggil, maka hanya variabel output saja yang berubah setiap saat bekerja. Misalnya, disusun sebuah functions file dengan nama nolitas.sci utuk menghitung nolitas matriks sebagai berikut:

function $\mathrm{k}=\operatorname{nolitas}(\mathrm{A})$ 
$\%$ perintah nolitas(A) akan menghitung dimensi

$\%$ ruang nol dari A.

[n_baris, n_kolom] = size $(A)$;

$\mathrm{k}=\mathrm{n}_{-} \mathrm{kolom}-\operatorname{rank}(\mathrm{A})$;

Baris dengan tanda \% merupakan komentar dan tidak akan dieksekusi. Bila function files tersebut disimpan, fungsi tersebut dapat dipakai sebagaimana perintah Scilab biasa. Misalnya, jika kita tetapkan

$$
\text { Test_matriks }=\left[\begin{array}{lllllllll}
1 & 2 & 3 ; & 4 & 5 & 6 ; & 7 & 8 & 9
\end{array}\right]
$$

kemudian kita gunakan perintah :

$$
\mathrm{n}=\text { nolitas (Test_matriks) }
$$

Scilab akan memberikan jawaban $: \mathrm{n}=1$.

\section{Fungsi pembangkit matriks.}

Sejumlah fungsi pembangkit matriks yang cukup bermanfaat antara lain :

$\begin{array}{ll}\text { eye } & \text { matriks identitas } \\ \text { zeros } & \text { matriks nol } \\ \text { ones } & \text { matriks satu } \\ \text { diag } & \text { lihat di bawah } \\ \text { triu } & \text { bagian segi tiga atas sebuah matriks } \\ \text { tril } & \text { bagian segi tiga bawah sebuah matriks } \\ \text { rand } & \text { matriks yang dibangkitkan secara acak } \\ \text { toeplitz } & \text { see help toeplitz }\end{array}$

Misalnya, zeros $(\mathrm{m}, \mathrm{n})$ menghasilan sebuah matriks nol berukuran $m$-kali- $n$ zeros $(\mathrm{n}, \mathrm{n})$ menghasilan sebuah matriks nol berukuran $n$-kali- $n$; jika $A$ sebuah matriks, maka zeros (A) menghasilan sebuah matriks nol berukuran sama dengan ukuran $A$. 
Jika $x$ sebuah vektor, diag(x) ialah sebuah matriks diagonal dengan $x$ sepanjang diagonalnya; jika $A$ sebuah matriks segi, maka diag(A) ialah sebuah vektor yang isinya diagonal dari $A$. Lalu apakah diag(diag(A))? Cobalah.

Matriks dapat dibangun dari blok. Misalnya, jika $A$ sebuah matriks berukuran 3-kali-3, maka

$$
B=[A, \operatorname{zeros}(3,2) ; \operatorname{zeros}(2,3), \text { eye }(2,2)]
$$

akan merupakan sebuah matriks tertentu berukuran 5-kali-5. 


\section{PENULIS}

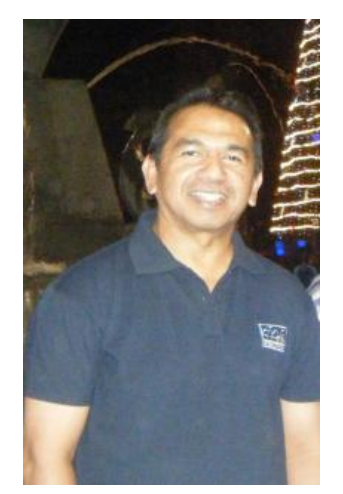

Gambar 5.1: Effendi Syahril lulus Sarjana Matematika dari Institut Teknologi Bandung, dengan konsentrasi Matematika Terapan. Mendapatkan pendidikan Pasca Sarjana dalam bidang Applied Mathematics dari The Universty of Adelaide, Adelaide, Australia. Atas biaya AIDAB, mendalami bidang Quantitative Finance selama empat tahun di tempat yang sama. Terakhir selama 4 tahun berkesempatan menjadi peneliti di UNISA, Adelaide, Australia, mendalami Islamic Quantitative Finance. SINTA ID : 0030106008 


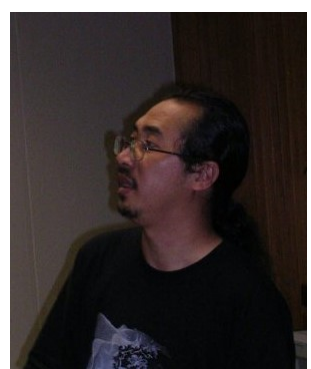

Gambar 5.2: Agah D Garnadi lulus Sarjana Matematika dari Institut Teknologi Bandung, dengan konsentrasi Matematika Murni. Mendapatkan pendidikan Pasca Sarjana dalam bidang Scientific Computing dengan minor matematika murni dari The Australian National Universty, Canberra, Australia. Sempat bekerja sebagai asisten peneliti dalam Metode Elemen Hingga di Dept. Engineering, ANU. Atas biaya DAAD mendalami bidang Teknomathematik dan Finanzmathematik di TU-Kaiserslautern, Jerman. Kemudian bekerja sebagai Scientific Programmer selama dua tahun di Crystal Growth Group, CAESAR, Bonn, dengan tugas utama perancangan dan simulasi tungku kristal industri semikonduktor. Kemudian selama 4 tahun berkesempatan menjadi peneliti tamu di Institut fuer Numerische und Angewandte Mathematik, Georg-August Universitaet Goettingen. SINTA ID : 6015353 